\title{
Development of Alkaline Oxidative Dissolution Methods for Chromium(III) Compounds Present in Hanford Site Tank Sludges
}

N. N. Krot ${ }^{(a)}$

V.P. Shilov ${ }^{(a)}$

A. M. Fedoseev ${ }^{(a)}$

N. A. Budantseva ${ }^{(a)}$

M. V. Nikonov ${ }^{(a)}$

A. B. Yusov ${ }^{(a)}$
A. Yu.Garnov ${ }^{(a)}$
I. A. Charushnikova ${ }^{(a)}$
V.P. Perminov ${ }^{(a)}$
L. N. Astafurova ${ }^{(a)}$
T. S. Lapitskaya ${ }^{(a)}$
V. I. Makarenkov (a)

June 1999

Prepared for the

U. S. Department of Energy

under Agreement between DOE and IPC RAS, August 1, 1998

Pacific Northwest National Laboratory

Richland, Washington

(a) Institute of Physical Chemistry

Russian Academy of Sciences 



\section{DISCLAIMER}

This report was prepared as an account of work sponsored by an agency of the United States Government. Neither the United States Government nor any agency thereof, nor any of their employees, make any warranty, express or implied, or assumes any legal liability or responsibility for the accuracy, completeness, or usefulness of any information, apparatus, product, or process disclosed, or represents that its use would not infringe privately owned rights. Reference herein to any specific commercial product, process, or service by trade name, trademark, manufacturer, or otherwise does not necessarily constitute or imply its endorsement, recommendation, or favoring by the United States Government or any agency thereof. The views and opinions of authors expressed herein do not necessarily state or reflect those of the United States Government or any agency thereof. 


\section{DISCLAIMER}

Portions of this document may be illegible in electronic image products. Images are produced from the best available original document. 


\section{Summary}

The high-level radioactive waste sludge in the underground storage tanks at the Hanford Site contains various chromium(III) solid phases. Dissolution and removal of chromium from tank waste sludges is desirable prior to high-level waste vitrification because increased volume is required to incorporate the residual chromium. Unfortunately, dissolution of chromium from the sludge to form $\mathrm{Cr}(\mathrm{OH})_{4}^{-}$through treatment with heated $\mathrm{NaOH}$ solution (also used to dissolve aluminum phases and metathesize phosphates to sodium salts) generally has been unsuccessful in tests with both simulated and genuine Hanford waste sludges. Oxidative dissolution of the $\mathrm{Cr}(\mathrm{III})$ compounds to form soluble chromate has been proposed as an alternative chromium solid phase dissolution method and results of limited prior testing have been reported.

The present systematic tests investigated oxygen gas, hydrogen peroxide, and sodium persulfate oxidants to dissolve $\mathrm{Cr}$ (III) under alkaline conditions to form soluble chromate. Permanganate and ozone also were considered for testing but were thought to be of secondary interest because of the insoluble residue $\left(\mathrm{MnO}_{2}\right.$ from permanganate) and complex equipment (necessary to generate ozone) implicit with use of these reagents. The oxygen and hydrogen peroxide reagents leave no condensable residue and sodium persulfate only leaves soluble sodium sulfate.

Crystalline $\mathrm{Cr}(\mathrm{OH})_{3}$, various hydrothermally aged amorphous $\mathrm{Cr}(\mathrm{III})$ oxide hydrates, mixed $\mathrm{Fe}$ (III)/Cr(III) oxide hydrates, and nickel and iron $\mathrm{Cr}$ (III) spinels, all of which have been identified or are likely constituents in Hanford tank wastes, were prepared and characterized for the dissolution tests. The effects of reagent and hydroxide concentrations, reaction temperature, and transition metal catalysts on reaction progress were investigated for each reagent as functions of reaction time. Reaction progress was measured by monitoring chromate concentration.

Oxidation of chromium compounds by dissolved oxygen was found to increase linearly with oxygen partial pressure and $\mathrm{NaOH}$ concentration. The rate also increased with temperature at low activation energy, $26-36 \mathrm{~kJ} / \mathrm{mol}$, reflecting the opposing influences of decreasing oxygen solubility and increasing underlying chemical reaction rate. The reaction apparently proceeds by way of dissolved $\mathrm{Cr}$ (III) species, is catalyzed by $\mathrm{Ni}$ (II), and is slower for the hydrothermally aged materials. Dissolution rates ranged from about $7 \times 10^{-5}$ to $2.4 \times 10^{-4}$ moles $\mathrm{Cr}(\mathrm{m}) /$ liter-hour in $80^{\circ} \mathrm{C}, 3-\mathrm{M} \mathrm{NaOH}$ with one atmosphere pure oxygen for the various $\mathrm{Cr}$ (III) compounds tested. These low dissolution rates commend the use of oxygen reagent to waste tank processing where extended residence times may be practical.

Oxidative dissolution of $\mathrm{Cr}(\mathrm{II})$ compounds by hydrogen peroxide was hampered in the presence of greater than $0.5 \mathrm{~g} \mathrm{Fe}$ (III)/liter and other catalysts for $\mathrm{H}_{2} \mathrm{O}_{2}$ decomposition and was less effective for materials that had undergone prolonged aging at high temperatures. Leaching was optimized at low excess $\mathrm{NaOH}$ and high temperatures (activation energy of $-82 \mathrm{~kJ} / \mathrm{mol}$ ). To prevent excessive loss of $\mathrm{H}_{2} \mathrm{O}_{2}$ to catalytic decomposition, the peroxide reagent must be added slowly and with intense stirring. Treatment of waste solids with $\mathrm{H}_{2} \mathrm{O}_{2}$ may only be attractive for freshly formed $\mathrm{Cr}$ (III) hydroxides [formed, for example, by alkaline metathesis of $\mathrm{Cr}$ (III)-bearing sludges] in the absence of decomposition catalysts such as $\mathrm{Fe}$ (III).

Oxidative dissolution of $\mathrm{Cr}$ (III) solid phases by persulfate was not strongly affected by the $\mathrm{Cr}$ (III) phase being tested. Even crystalline $800^{\circ} \mathrm{C}$-fired $\mathrm{Cr}_{2} \mathrm{O}_{3}$ and $\mathrm{NiCr}_{2} \mathrm{O}_{4}$ spinel were oxidatively dissolved by persulfate though at slightly slower rates. The stoichiometry of one mole $\mathrm{Cr}$ (III) oxidized per 1.5 moles persulfate was observed. Optimum process conditions were $\sim 70^{\circ} \mathrm{C}$ and 0.3 to $0.5 \mathrm{M}$ excess $\mathrm{NaOH}$. Higher temperatures and $\mathrm{NaOH}$ concentrations can lead to thermal decomposition of the oxidant in side reactions. The $\mathrm{Cr}$ (III) oxidation reaction was catalyzed by $\mathrm{Co}(\mathrm{II}), \mathrm{Ni}(\mathrm{II}), \mathrm{Cu}(\mathrm{II})$, and $\mathrm{Fe}(\mathrm{III})$. In $70^{\circ} \mathrm{C}$, 
$2 \mathrm{M} \mathrm{NaOH}$ with four-fold excess persulfate, $\mathrm{Cr}(\mathrm{III})$ hydrated oxide initial dissolution rates on the order of $(2$ to 5$) \times 10^{-3}$ moles/liter-minute were observed. The rapid reaction rates obtained with persulfate commend its use in process reactors. The persulfate reaction product is soluble sulfate; the sulfate partitions to the low-activity solution.

With strong oxidants, oxidative dissolution of plutonium oxide or sorbed $\mathrm{Pu}(\mathrm{IV})$ also can occur in alkaline solution. The oxygen and hydrogen peroxide reagents are not strong enough to promote $\mathrm{Pu}$ (IV) to the more soluble (V) or (VI) oxidation states and thus should not enhance plutonium solution concentrations. Persulfate, however, is strong enough to oxidatively dissolve plutonium. Fortunately, a simple method, thermal decomposition of excess persulfate followed by reduction of oxidized plutonium by $\mathrm{H}_{2} \mathrm{O}_{2}$ addition, should cause reprecipitation of the dissolved plutonium without causing unwanted reduction and precipitation of chromium.

These parametric tests have identified the range of optimum conditions for oxidative dissolution of $\mathrm{Cr}$ (III) from various simulant sludge phases using oxygen, hydrogen peroxide, and persulfate oxidants. However, it is necessary to test these reagents for their effects on genuine wastes to ensure their process efficacy. 


\section{Contents}

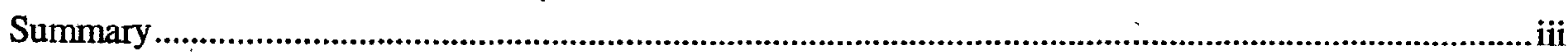

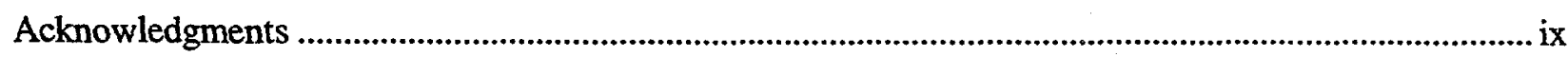

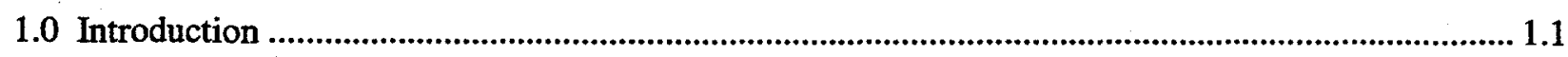

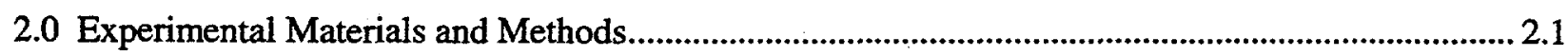

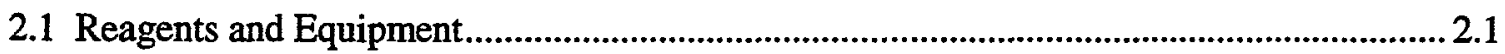

2.2 Preparation of the Chromium Solid Phases ................................................................. 2.1

2.3 Characteristics of the Chromium Solid Phases............................................................... 2.4

2.4 Experimental Procedure for Tests with Oxygen ............................................................... 2.9

2.5 Experimental Procedure for Tests with Hydrogen Peroxide ............................................... 2.9

2.6 Experimental Procedure for Tests with Persulfate ............................................................ 2.10

3.0 Oxidative Alkaline Dissolution of Chromium(II) Compounds by Gaseous Oxygen........................ 3.1

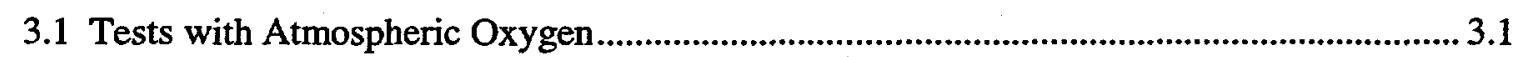

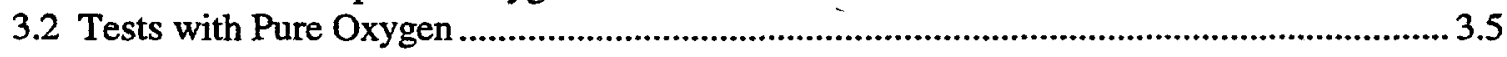

4.0 Oxidative Alkaline Dissolution of Chromium(III) Compounds by Hydrogen Peroxide.................... 4.1

4.1 Effect of Conditions on the Rate of $\mathrm{Cr}$ (III) Hydroxide Oxidation by $\mathrm{H}_{2} \mathrm{O}_{2}$....................... 4.1

4.2 $\mathrm{Cr}$ (III) Hydroxide Oxidation by $\mathrm{H}_{2} \mathrm{O}_{2}$ in the Presence of Some Catalysts ........................... 4.5

4.3 Rate of Oxidation of Other $\mathrm{Cr}(\mathrm{III})$ Compounds by $\mathrm{H}_{2} \mathrm{O}_{2}$ in Alkaline Media ...................... 4.6

$4.4 \mathrm{H}_{2} \mathrm{O}_{2}$ Consumption in the Complete Oxidation of $\mathrm{Cr}(\mathrm{III})$ Hydroxides............................... 4.7

5.0 Oxidative Alkaline Dissolution of Chromium(III) Compounds by Persulfate.................................. 5.1

5.1 Data on the Kinetics and Mechanism of $\mathrm{Cr}$ (III) Hydroxide Oxidation ............................... 5.1

5.2 Data on Persulfate Reactions with Other Cr(III) Compounds ..............................................5.5

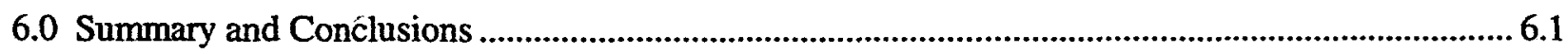

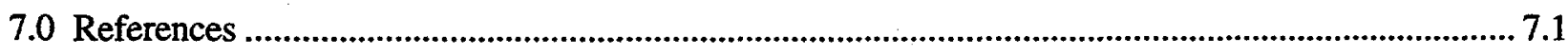




\section{Figures}

2.1 Diffractogram of $\mathrm{Cr}(\mathrm{OH})_{3} \cdot 3 \mathrm{H}_{2} \mathrm{O}$ 2.4

2.2 Diffractograms of Cr(III) Hydroxide Compounds II, III, V, VI, IX, and VII ................................ 2.5

2.3 Volumetric Particle Size Distribution for $\mathrm{Cr}$ (III) Hydroxide Compounds ........................................ 2.6

2.4 Infrared Spectra of Some $\mathrm{Cr}(\mathrm{III})$ Hydroxide Compounds ...............................................................

2.5 Diffractograms of $\mathrm{Cr}(\mathrm{III})$ Compounds XIV, XII, XIII, and X ................................................ 2.7

2.6 Infrared Spectra of Some $\mathrm{Cr}(\mathrm{III}) / \mathrm{Fe}(\mathrm{III})$ Hydroxide Compounds................................................. 2.7

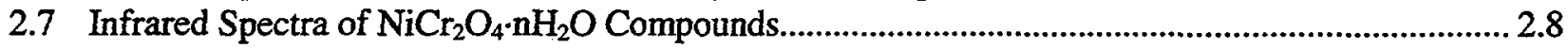

3:1 Kinetics of $0.02 \mathrm{M} \mathrm{Cr}$ (III) Hydroxide (compound VIII) Oxidation

by Atmospheric Oxygen at $70^{\circ} \mathrm{C}$

3.2 Effect of Temperature on Rate of $\mathrm{Cr}$ (III) Hydroxide Oxidation by Atmospheric Oxygen in $3 \mathrm{M} \mathrm{NaOH}$ compounds II and V.

3.3 Long-Term Reaction of $\mathrm{Cr}$ (III) Compounds with Atmospheric Oxygen in $3 \mathrm{M} \mathrm{NaOH}$ at $80^{\circ} \mathrm{C}$, Compounds III and VI.

3.4 Long-Term Reaction of $\mathrm{Cr}$ (III) Compounds with Atmospheric Oxygen in $3 \mathrm{M} \mathrm{NaOH}$ at $80^{\circ} \mathrm{C}$, Compounds V and VIII.

3.5 Long-Term Reaction of $\mathrm{Cr}$ (III) Compounds with Atmospheric Oxygen in $3 \mathrm{M} \mathrm{NaOH}$ at $80^{\circ} \mathrm{C}$, Compounds $\mathrm{XII}$ and $\mathrm{X}$

3.6. Kinetics of $0.02 \mathrm{M} \mathrm{Cr}$ (III) Hydroxide (compound II) Oxidation by Pure Oxygen at $70^{\circ} \mathrm{C}$.............. 3.5

3.7 Influence of $\mathrm{O}_{2}$ Pressure on the Oxidation Rate of $0.02 \mathrm{M} \mathrm{Cr}$ (III) Hydroxide (compound $\mathrm{m}$ ) in $3 \mathrm{M} \mathrm{NaOH}$ at $70^{\circ} \mathrm{C}$

3.8 Effect of Temperature on the Rate of $\mathrm{Cr}$ (III) Hydroxide (compound $\mathrm{I}$ ) Oxidation by Pure Oxygen

3.9 Long-Term Reaction of $\mathrm{Cr}(\mathrm{III})$ Hydroxides with 1 atm Pure Oxygen in $3 \mathrm{M} \mathrm{NaOH}$ at $80^{\circ} \mathrm{C} \ldots \ldots . . .3 .8$

3.10 Long-Term Reaction of $\mathrm{Cr}$ (III) Compounds with1 atm Pure Oxygen in $3 \mathrm{M} \mathrm{NaOH}$ at $80^{\circ} \mathrm{C}$.......... 3.9

3.11 Long-Term Reaction of $\mathrm{Cr}$ (III) Hydroxides with Pure Oxygen with 2 atm Pressure in $3 \mathrm{M} \mathrm{NaOH}$ at $80^{\circ} \mathrm{C}$

4.1 Kinetics of Oxidation of $0.02 \mathrm{M} \mathrm{Cr}$ (III) Hydroxide (Compound II) by $0.1 \mathrm{M} \mathrm{H}_{2} \mathrm{O}_{2}$ at $50^{\circ} \mathrm{C}$.

4.2 Effect of [ $\mathrm{Cr}$ (III) $]_{0}$ on the Rate of $\mathrm{Cr}_{2} \mathrm{O}_{3} \cdot 4 \mathrm{H}_{2} \mathrm{O}$ Oxidation (Compound $\mathrm{I}$ ) by $0.04 \mathrm{M} \mathrm{H}_{2} \mathrm{O}_{2}$ at $60^{\circ} \mathrm{C}$ in $3 \mathrm{M} \mathrm{NaOH}$.

4.3 Effect of $\mathrm{H}_{2} \mathrm{O}_{2}$ Concentration on the Initial Rate of Oxidation of $0.02 \mathrm{M} \mathrm{Cr}$ (III) Hydroxide (Compound II) in $3 \mathrm{M} \mathrm{NaOH}$

4.4 Effect of Temperature on the Initial Oxidation Rate of $0.02 \mathrm{M} \mathrm{Cr}$ (III) Hydroxide by $0.04 \mathrm{M} \mathrm{H}_{2} \mathrm{O}_{2}$ in $0.5 \mathrm{M} \mathrm{NaOH}$.

5.1 Kinetics of Oxidation of $0.05 \mathrm{M} \mathrm{Cr}$ (III) Hydroxide (Compound II) by $0.2 \mathrm{M} \mathrm{S}_{2} \mathrm{O}_{8}{ }^{2-}$ in $0.5 \mathrm{M} \mathrm{NaOH}$

5.2 Effect of Initial $\mathrm{Cr}$ (III) Concentration on the Initial Oxidation Rate of $\mathrm{Cr}$ (III) Hydroxide (Compound II) by $0.2 \mathrm{M} \mathrm{S}_{2} \mathrm{O}_{8}{ }^{2-}$ at $71^{\circ} \mathrm{C}$ in $0.5 \mathrm{M} \mathrm{NaOH}$

5.3 Effect of Initial $\mathrm{S}_{2} \mathrm{O}_{8}{ }^{2-}$ Concentration on the Initial Oxidation Rate of $0.034 \mathrm{M} \mathrm{Cr}$ (III) Hydroxide (compound III) in $2 \mathrm{M} \mathrm{NaOH}$ at $50^{\circ} \mathrm{C}$

5.4 Effect of Temperature on the Initial Oxidation Rate of $0.05 \mathrm{M} \mathrm{Cr}$ (III) Hydroxide (Compound II) by $0.2 \mathrm{M} \mathrm{S}_{2} \mathrm{O}_{8}{ }^{2-}$ in $0.5 \mathrm{M} \mathrm{NaOH}$

5.5 Effect of $\mathrm{NaOH}$ Concentration on the Initial Oxidation Rate of $0.05 \mathrm{M} \mathrm{Cr}(\mathrm{III})$ Hydroxide (Compound II) by $0.2 \mathrm{M} \mathrm{S}_{2} \mathrm{O}_{8}{ }^{2-}$ at $71^{\circ} \mathrm{C}$............................................. 5.4

5.6 Diffractograms of $\mathrm{Cr}$ (III) Oxides

5.7 Diffractograms of $\mathrm{NiCr}_{2} \mathrm{O}_{4} \cdot$ Materials . 5.7 


\section{Tables}

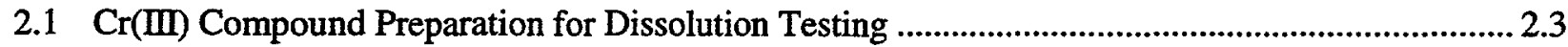

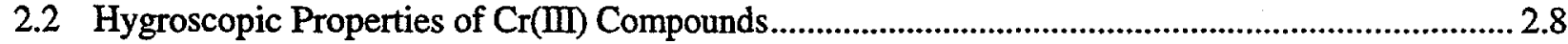

3.1 Effect of $\mathrm{NaOH}$ Concentration on the Oxidation Rate of $0.02 \mathrm{M} \mathrm{Cr}$ (III)

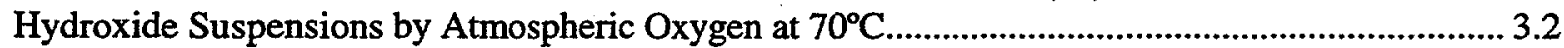

3.2 Effect of Temperature and $\mathrm{Cr}$ (III) Compound Initial Concentration on $\mathrm{Cr}$ (III) Hydroxide Oxidation by Atmospheric Oxygen in $3 \mathrm{M} \mathrm{NaOH}$.

3.3 Initial Reaction Rate, $\mathrm{V}_{\mathrm{o}}$, for the Oxidation of $\mathrm{Cr}$ (III) Compounds by Atmospheric Oxygen in $3 \mathrm{M} \mathrm{NaOH}$...

3.4 Influence of Reaction Conditions on the Initial Rate of Cr(III) Hydroxide (compound II) Oxidation by Oxygen

3.5 Comparison of the Oxidation Rates of Different $\mathrm{Cr}$ (III) Hydroxides by Oxygen

3.6 Comparison of the Oxidation Rates of Different $\mathrm{Cr}$ (III) Compounds by Oxygen

4.1 Initial Rate of $\mathrm{Cr}_{2} \mathrm{O}_{3} \cdot 4 \mathrm{H}_{2} \mathrm{O}$ (compound II) Oxidation by $\mathrm{H}_{2} \mathrm{O}_{2}$ in $3 \mathrm{M} \mathrm{NaOH}$.

4.2 Influence of Temperature and $\mathrm{NaOH}$ Concentration on Initial Rate of $0.02 \mathrm{M} \mathrm{Cr}_{2} \mathrm{O}_{3} \cdot 4 \mathrm{H}_{2} \mathrm{O}$ (compound II) Oxidation by $\mathrm{H}_{2} \mathrm{O}_{2}$

4.3 Initial Rate of $\mathrm{Cr}$ (III) Hydroxide Oxidation by $0.04 \mathrm{M} \mathrm{H}_{2} \mathrm{O}_{2}$

4.4 Oxidation of $0.02 \mathrm{M} \mathrm{Cr}_{2} \mathrm{O}_{3} \cdot 4 \mathrm{H}_{2} \mathrm{O}$ (compound II) in $0.5 \mathrm{M} \mathrm{NaOH}$ by $0.04 \mathrm{M} \mathrm{H}_{2} \mathrm{O}_{2}$ in the Presence of Catalysts

4.5 Initial Oxidation Rate of Some $\mathrm{Cr}$ (III) Compounds by $0.04 \mathrm{M} \mathrm{H}_{2} \mathrm{O}_{2}$

4.6 Consumption of $\mathrm{H}_{2} \mathrm{O}_{2}$ for $\mathrm{Cr}$ (III) Hydroxide (compound II) Oxidation in Alkaline Solutions

4.7 Consumption of $\mathrm{H}_{2} \mathrm{O}_{2}$ for Complete $\mathrm{Cr}$ (III) Hydroxide (compound II) Oxidation in $70^{\circ} \mathrm{C} 2 \mathrm{M} \mathrm{NaOH}$ in the Presence of Catalysts.

4.8 Oxidation of $0.022 \mathrm{M}$ Aged $\mathrm{Cr}$ (III) Hydroxides in $0.3 \mathrm{M} \mathrm{NaOH}$ by $\mathrm{H}_{2} \mathrm{O}_{2}$

4.9 Interaction of $\mathrm{NiCr}_{2} \mathrm{O}_{4} \cdot \mathrm{nH}_{2} \mathrm{O}$ (compounds $\mathrm{X}$ and $\mathrm{XI}$ ) and $\mathrm{Fe}_{0.67} \mathrm{Cr}_{1.33} \mathrm{O}_{3} \cdot 2 \mathrm{H}_{2} \mathrm{O}$ (compounds XII and XIII) with $1 \mathrm{M} \mathrm{H}_{2} \mathrm{O}_{2}$ in $0.3 \mathrm{M} \mathrm{NaOH}$

5.1 Yield of $\mathrm{Cr}(\mathrm{VI})$ after Completion of the $\mathrm{Cr}_{2} \mathrm{O}_{3} \cdot 4 \mathrm{H}_{2} \mathrm{O}$ Reaction with Persulfate

5.2 Effect of Composition on the Initial Rates of $\mathrm{Cr}(\mathrm{III})$ Hydroxide Oxidation by $\mathrm{S}_{2} \mathrm{O}_{8}{ }^{2-}$.........

5.3 Effect of Temperature and $\mathrm{NaOH}$ Concentration on the Initial Rate of $0.05 \mathrm{M} \mathrm{Cr}$ (III) (compound II) Oxidation by $0.2 \mathrm{M} \mathrm{S}_{2} \mathrm{O}_{8}{ }^{2-}$.

5.4 Effect of $0.03 \mathrm{M} \mathrm{Cr}$ (III) Hydroxide Compound on Its Oxidation Rate by $0.2 \mathrm{M}$ Persulfate

5.5 Oxidation of Different $\mathrm{Cr}$ (III) Compounds by $0.2 \mathrm{M}$ Persulfate in $2 \mathrm{M} \mathrm{NaOH}$.

5.6 Initial Oxidation Rate of $0.03 \mathrm{M} \mathrm{Cr}$ (III) Hydroxide by $0.2 \mathrm{M}$ Persulfate in $50^{\circ} \mathrm{C} 2 \mathrm{M} \mathrm{NaOH}$ in the Presence of Some Catalysts. 



\section{Acknowledgments}

This work was performed at the Laboratory of Transuranium Element Chemistry of the Institute of Physical Chemistry, Russian Academy of Sciences (IPC/RAS), under an agreement between the U.S. Department of Energy and the IPC/RAS. The work was supported by the U.S. Department of Energy, Office of Science and Technology, under the Office of Environmental Management.

We are very thankful to Dr. Kurt Gerdes, Program Manager, and Dr. Jerry Harness, Efficient Separations and Processing Crosscutting Program, for their active interest in our research. We also thank Dr. Jack Watson, Deputy Coordinator, for his useful advice and support. We acknowledge with thanks the organizational efforts of Dr. Thomas Albert in contract implementation. And finally we acknowledge Cal Delegard, Pacific Northwest National Laboratory, for his attention to our work, discussions, and editorial assistance. 


\subsection{Introduction}

The high-level radioactive waste in underground storage tanks at the Hanford Site is alkaline and consists of solid crystalline salts (for example, sodium nitrate, nitrite, carbonate, phosphate), alkaline sludges of low solubility (transition metal hydroxides and phosphates, aluminum hydroxide, aluminosilicates), and the associated alkaline solutions. The wastes will be segregated into high-activity and low-activity streams before their separate vitrification and final disposal. The high-activity stream will contain most of the radionuclides and the bulk waste chemicals associated with the waste sludge. The low-activity stream will contain most of the alkali-soluble waste chemicals (primarily sodium salts) but relatively low concentrations of the radionuclides. Certain bulk components in the tank waste sludge (primarily aluminum, phosphate, and chromium) have relatively low solubilities in the waste glass compared with their inventories in the waste, and, if they remain in the waste sludge, will contribute significantly to the volume of the high-activity glass. Therefore, it is desirable to remove these dissolved nonradioactive components from the sludge by leaching and relegate them to the low-activity vitrified stream. Hot solutions of $3 \mathrm{M} \mathrm{NaOH}$ can be used to leach aluminum and phosphate phases [Lumetta et al. 1997]. However, chromium leaching by strong alkali is often insufficient [Lumetta et al. 1997] because of the very low solubility of aged $\mathrm{Cr}(\mathrm{III})$ hydroxide in hot $\mathrm{NaOH}$ solutions to form the $\mathrm{Cr}(\mathrm{OH})_{4}{ }^{\circ}$ dissolved species [Felmy et al. 1994]. Instead, oxidation of $\mathrm{Cr}(\mathrm{III})$ compounds to form soluble chromate $\left(\mathrm{CrO}_{4}{ }^{2-}\right)$ must be used as an alternative method to dissolve chromium from the alkaline tank sludge.

As shown in the technical literature [Berka et al. 1961; Gmelin 1963], oxygen gas, hydrogen peroxide, persulfate, permanganate, and ozone are effective $\mathrm{Cr}$ (III) oxidants in alkaline media. Of these reagents, oxygen, hydrogen peroxide, and persulfate are the most attractive for oxidative leaching of $\mathrm{Cr}$ (III) solids from Hanford tank sludges because they do not contribute to the sludge volume as permanganate does [Rapko 1998] and do not require specialized equipment as ozone does [Delegard et al. 1993]. The residual sodium sulfate produced from the persulfate oxidant is soluble in alkaline solution and should report to the low-activity stream while the oxygen gas and hydrogen peroxide leave no condensable residue.

The ability of oxygen to oxidize $\mathrm{Cr}$ (III) compounds in alkaline media has been known for a long time [Gmelin 1963]. However, this process was studied in detail only at rather high temperatures and pressures [Farrow and Burkin 1975]. Recently, several tests were performed to evaluate $\mathrm{Cr}$ (III) leaching by treating Hanford tank sludge with oxygen at atmospheric pressure [Rapko 1998]. The tests showed that nearly complete dissolution of $\mathrm{Cr}$ (III) compounds from genuine alkali-leached sludge residues from Tanks 241-U-108, 241-U-109, and 241-SX-108 could be achieved by bubbling pure $\mathrm{O}_{2}$ through $80^{\circ} \mathrm{C}$, 3$\mathrm{M} \mathrm{NaOH}$ suspensions of the respective sludges for four to six days. The reaction rate decreased significantly if $0.1 \mathrm{M} \mathrm{NaOH}$ were used.

Oxidative alkaline dissolution of $\mathrm{Cr}(\mathrm{III})$ solids by oxygen thus is a highly appealing method to remove chromium from Hanford tank sludge before its vitrification. However, the process must be studied more thoroughly and systematically to determine the optimum conditions of its performance. Parametric study of oxidation of $\mathrm{Cr}$ (III) solids by oxygen was one of the tasks of the present investigation.

Information on the interaction of $\mathrm{Cr}(\mathrm{III})$ solid phases with hydrogen peroxide $\left(\mathrm{H}_{2} \mathrm{O}_{2}\right)$ is limited. According to early data, no reaction takes place in acidic or neutral media. In hot $\mathrm{KOH}$ solution, complete oxidation of $\mathrm{Cr}(\mathrm{III})$ was observed only by use of a five-fold stoichiometric excess of $\mathrm{H}_{2} \mathrm{O}_{2}$ [Gmelin 1963]. Application of hydrogen peroxide in $3 \mathrm{M} \mathrm{NaOH}$ to leach $\mathrm{Cr}$ (III) from sludge residues remaining after alkaline washing of simulated Tank 241-SY-101 waste and genuine wastes from Tanks 241-SY-101 and 241-SY-102 was tested recently at room temperature [Delegard 1995]. Though 
effective $\mathrm{Cr}$ (III) oxidation was found for the simulant waste, little leaching was found for the genuine wastes. The low extent of leaching observed in the tests with genuine wastes may have been caused by the low oxidation reaction rate in comparison with the parasitic catalytic decomposition of $\mathrm{H}_{2} \mathrm{O}_{2}$ under the studied test conditions. To verify this assumption, the reaction of $\mathrm{Cr}_{2} \mathrm{O}_{3}$ with $\mathrm{H}_{2} \mathrm{O}_{2}$ was tested at room and elevated $\left(80^{\circ} \mathrm{C}\right)$ temperatures [Rapko et al. 1997]. These tests also gave poor dissolution, probably because crystalline $\mathrm{Cr}_{2} \mathrm{O}_{3}$ is a very stable compound and acted mainly as a catalyst to decompose $\mathrm{H}_{2} \mathrm{O}_{2}$ [Voltz and Weller 1954]. In addition, crystalline $\mathrm{Cr}_{2} \mathrm{O}_{3}$ is not likely to be present in Hanford tank sludge because its crystallization in alkaline media only proceeds above $400^{\circ} \mathrm{C}$ [Ratnasamy and Leonard 1972; Mikhail and Selim 1974; Viktorov et al. 1994]. Based on the mixed results found for hydrogen peroxide, study of the oxidation of different $\mathrm{Cr}$ (III) compounds by hydrogen peroxide in alkali solutions over a wide range of conditions was undertaken as a separate goal of the present investigation.

The interaction of $\mathrm{Cr}$ (III) with persulfate primarily has been studied in acid solutions. Results on the reaction in alkaline media are old and limited [Gmelin 1963]. The early studies show that the process does not proceed at room temperature whereas $\mathrm{Cr}$ (III) is oxidized by persulfate easily and completely in boiling $\mathrm{NaOH}$ or $\mathrm{KOH}$ solutions. The promising but limited findings for persulfate motivated study of $\mathrm{Cr}$ (III) alkaline oxidation by persulfate for its use in processing Hanford tank sludge. 


\subsection{Experimental Materials and Methods}

\subsection{Reagents and Equipment}

Reagent-grade $\mathrm{Cr}\left(\mathrm{NO}_{3}\right)_{3} \cdot 9 \mathrm{H}_{2} \mathrm{O}, \mathrm{Cr}\left(\mathrm{OOCCH}_{3}\right)_{3} \cdot 9 \mathrm{H}_{2} \mathrm{O}, \mathrm{CrCl}_{3} \cdot 6 \mathrm{H}_{2} \mathrm{O}, \mathrm{Fe}\left(\mathrm{NO}_{3}\right)_{3} \cdot 9 \mathrm{H}_{2} \mathrm{O}, \mathrm{FeSO}_{4} \cdot 7 \mathrm{H}_{2} \mathrm{O}$, and $\mathrm{Ni}\left(\mathrm{NO}_{3}\right)_{2} \cdot 6 \mathrm{H}_{2} \mathrm{O}$ were used to prepare standard solutions of $\mathrm{Cr}(\mathrm{III}), \mathrm{Fe}$ (III), $\mathrm{Fe}$ (II), and $\mathrm{Ni}$ (II), respectively. Solution concentrations were determined by gravimetric analyses after evaporation of measured volumes $(0.1 \mathrm{~mL})$ of the solutions in platinum crucibles and calcination of the residues to their respective oxides. Standard 1-M S $\mathrm{S}_{2} \mathrm{O}_{8}{ }^{2-}$ solutions were prepared using chemical-grade $\mathrm{Na}_{2} \mathrm{~S}_{2} \mathrm{O}_{8}$. The solutions were analyzed by iodometric titration and stored in a refrigerator.

Working sodium hydroxide solutions were obtained by the dilution of $16.7-\mathrm{M}$ chemical puritygrade $\mathrm{NaOH}$; they were stored in polyethylene bottles. Standard solutions of other reagents were prepared by dissolving the salt $\left(\mathrm{NaNO}_{3}\right)$ in distilled water or by the dilution of respective solution reagents $\left(\mathrm{NH}_{4} \mathrm{OH}, \mathrm{H}_{2} \mathrm{O}_{2}\right)$.

Powder $\mathrm{x}$-ray diffraction patterns of solid samples were measured by an $\mathrm{x}$-ray diffractometer ADP10, using CuK $\mathrm{Cu}_{\alpha 1}$-radiation (Philips PW 1140/90/96 generator, Holland). To take infrared (IR) spectra, 2$2.5 \mathrm{mg}$ of compound were mixed with $200 \mathrm{mg}$ of special purity-grade $\mathrm{NaCl}$ and ground into powder for 10 to 20 minutes in an agate mortar. The pulverized mixture was pressed into a transparent $2-\mathrm{cm}$ diameter disk in a die at $190 \mathrm{kP} / \mathrm{cm}^{2}$ pressure. The disk was positioned in a special holder and placed in the compartment of an IR spectrophotometer (Specord-M80, Germany). The IR spectra were recorded in the range $350-4000 \mathrm{~cm}^{-1}$.

The particle size distributions of some initial $\mathrm{Cr}$ (III) hydroxides were determined using the smallangle $x$-ray scattering (SAXS) technique [Plavnik 1986]. The SAXS intensity measurements were performed using a KRM-1 instrument (Russia) in the interval 0.05 to 10 degrees with variable step scanning. The samples studied by the SAXS technique were mixed with small volumes of $\mathrm{C}_{2} \mathrm{H}_{5} \mathrm{OH}$ and uniform suspensions were placed as thin layers on a $0.02-\mathrm{mm}$ Mylar film. After drying to a paste, additional layers of the suspension were placed on the same film. Layering was repeated three to five times to obtain a final deposit containing 350 to $500 \mathrm{mg}$ over the $1 \times 2-\mathrm{cm}$ surface. Mylar film covered the samples to prevent further drying.

Thermostats (U-2 and U-10 models, Germany) were used to maintain constant $\left( \pm 0.2^{\circ} \mathrm{C}\right)$ solution temperature in the 30 to $90^{\circ} \mathrm{C}$ range. Precipitates were separated from supernatant liquids using medical centrifuges (model CLK-1, Russia) providing a field of 1,750-times the acceleration of gravity. Analytical sample masses were determined by a Sartorius microbalance with $\pm 1 \mu \mathrm{g}$ sensitivity.

\subsection{Preparation of the Chromium Solid Phases}

Hanford tank waste sludges differ significantly in origin and composition and are extremely inhomogeneous. The inhomogeneity is reflected in the $\mathrm{Cr}$ (III) compounds found in the sludges: $\mathrm{Al}_{1-x} \mathrm{Cr}_{x}(\mathrm{OH})_{3}$ (Cr-gibbsite), $\mathrm{Fe}_{1-x} \mathrm{Cr}_{x}(\mathrm{OH})_{3}$ (Cr-ferrihydrite), $\mathrm{CrOOH}$ (grimaldite) [Whyatt et al. 1996], $\mathrm{Fe}(\mathrm{Cr}, \mathrm{Fe})_{2} \mathrm{O}_{4}$ (donathite), and unidentifiable non-crystalline or poorly crystalline phases [Lumetta 1997] all have been found in various wastes. Some $\mathrm{Cr}(\mathrm{III})$ compounds might be expected to decompose, with the associated formation of $\mathrm{Cr}(\mathrm{III})$ hydroxides, by washing and caustic leaching of the tank sludge. The spinel-type phases, however, are stable to attack by alkali [Markina and Freire 1984]. Because of the 
diversity of phases observed in genuine Hanford tank wastes, $\mathrm{Cr}$ (III) hydroxide, mixed $\mathrm{Fe}$ (III)- $\mathrm{Cr}$ (III) hydroxide, and some representative spinel phases $\left[\mathrm{NiCr}_{2} \mathrm{O}_{4}\right.$ and $\left.\mathrm{Fe}(\mathrm{Cr}, \mathrm{Fe})_{2} \mathrm{O}_{4}\right]$ were prepared for the present dissolution investigations.

Because $\mathrm{Cr}$ (III) compounds are prepared industrially for catalysts and other applications, the synthesis and properties of $\mathrm{Cr}$ (III) hydroxides have been described in many publications. Information from the technical literature of special interest in the preparation of $\mathrm{Cr}$ (III)-bearing phases for the present work is summarized.

Chromium(III) hydroxide, precipitated at room temperature from nitrate solutions by a small excess of $\mathrm{NH}_{4} \mathrm{OH}$, is a crystalline compound having an orthorhombic lattice of $\alpha-\mathrm{Al}(\mathrm{OH})_{3}$ (bayerite) structure [Milligan 1951; Ratnasamy and Leonard 1972]. The compound is unstable and with long-term storage or heating to greater than $60^{\circ} \mathrm{C}$ transforms into an amorphous product; the amorphous $\mathrm{Cr}$ (III) hydroxide is also formed by precipitating $\mathrm{Cr}$ (III) with alkalis from either cold or hot solutions.

The amorphous $\mathrm{Cr}(\mathrm{III})$ hydroxide, precipitated and coagulated at 80 to $85^{\circ} \mathrm{C}$ and dried at $30^{\circ} \mathrm{C}$ in air, is hygroscopic [Giovanoli and Stadelmann 1973] with a composition described by the formula $\mathrm{Cr}(\mathrm{OH})_{3} \cdot 0.8 \mathrm{H}_{2} \mathrm{O}$ (or $\mathrm{Cr}_{2} \mathrm{O}_{3} \cdot 4.6 \mathrm{H}_{2} \mathrm{O}$ ) [Giacomelli et al. 1995]. With increasing temperature, the amorphous $\mathrm{Cr}(\mathrm{III})$ hydroxide loses water in a stepwise manner with endotherms at $120-150^{\circ} \mathrm{C}$ and $250^{\circ} \mathrm{C}$ and then converts, with a sharp exothermic effect (glow phenomenon) at about $400^{\circ} \mathrm{C}$, to form crystalline $\alpha-\mathrm{Cr}_{2} \mathrm{O}_{3}$ (corundum structure) [Ratnasamy and Leonard 1972; Giovanoli and Stadelmann 1973; Natarajan and Secco 1975].

The reported temperatures for $\alpha-\mathrm{Cr}_{2} \mathrm{O}_{3}$ formation from amorphous hydroxide differ significantly [Reznitskii et al. 1988; Shafer and Roy 1954]. However, these values are always higher than $380^{\circ} \mathrm{C}$. The temperature of $\alpha-\mathrm{Cr}_{2} \mathrm{O}_{3}$ crystallization seemingly depends on the initial conditions of $\mathrm{Cr}(\mathrm{III})$ hydroxide precipitation [Viktorov et al. 1994] and on the atmosphere and the heating rate used to convert to the oxide [Burwell et al. 1960; Kittaka et al. 1985; Klissurski and Bluskov 1983].

Information on the chemical nature of amorphous $\mathrm{Cr}$ (III) hydroxide and the dehydration products formed before $\alpha-\mathrm{Cr}_{2} \mathrm{O}_{3}$ crystallization differ with respect to the intermediate appearance of $\mathrm{CrOOH}$. The oxyhydroxide is known in three modifications: the rhombohedral ( $\mathrm{R} 3 \mathrm{~m}) \alpha$-form [Thamer et al. 1957], the orthorhombic (Pnnm) $\beta$-phase isostructural with InOOH [Christensen 1966], and the orthorhombic $(\mathrm{Cmcm}) \gamma$-form with a structure similar to böhmite $(\gamma$-AlOOH) or lepidocrocite $(\gamma$-FeOOH) [Hund 1959]. It was found that the amorphous products obtained by $60-240^{\circ} \mathrm{C}$ drying of crystalline $\mathrm{Cr}$ (III) hydroxide contain, in the arrangement of the oxygens nearest the $\mathrm{Cr}$ atom, elements of structure typical of $\gamma-\mathrm{CrOOH}$ and $\alpha-\mathrm{Cr}_{2} \mathrm{O}_{3}$ [Ratnasamy and Leonard 1972]. Crystalline $\alpha-\mathrm{CrOOH}$ forms upon prolonged hydrothermal $400^{\circ} \mathrm{C}$ treatment of $\mathrm{Cr}(\mathrm{III})$ hydroxide, especially in $\mathrm{NaOH}$ solutions [Laubengayer and McCune 1952]. However, studies by different physicochemical methods show the absence of any CrOOH phases as intermediates in the production of $\alpha-\mathrm{Cr}_{2} \mathrm{O}_{3}$ from $\mathrm{Cr}$ (III) hydroxide [Singh et al. 1983]. It may be that the $\mathrm{CrOOH}$ phases that form by high-temperature aging of $\mathrm{Cr}(\mathrm{III})$ hydroxide are very poorly crystalline.

Syntheses of different crystalline spinel-type chromites usually are conducted by calcining mixtures of the corresponding oxides at temperatures higher than $1000^{\circ} \mathrm{C}$ [Gmelin 1962 ; Ryabin et al. 1981]. The same compounds but in an amorphous state may be obtained by mutual precipitation of the respective hydroxides followed by precipitate coagulation at elevated temperatures [Yur'eva et al. 1968]. Similar methods can be used to prepare $\mathrm{Fe}(\mathrm{III}) / \mathrm{Cr}$ (III) hydroxide solid solutions [Sass and Rai 1987]. 
The $\mathrm{Cr}$ (III) compounds prepared for the present studies based on these literature findings are listed in Table 2.1. The compound compositions are for samples dried in a desiccator over $\mathrm{KOH}$ pellets. Methods used in the syntheses are described in the following paragraphs.

To prepare crystalline $\mathrm{Cr}(\mathrm{OH})_{3} \cdot 3 \mathrm{H}_{2} \mathrm{O}$ (or $\mathrm{Cr}_{2} \mathrm{O}_{3} \cdot 9 \mathrm{H}_{2} \mathrm{O}$; compound $\mathrm{I}$ ), $10 \mathrm{~mL}$ of $0.1 \mathrm{M} \mathrm{Cr}(\mathrm{III})$ nitrate was added slowly, with intense stirring, to $25 \mathrm{~mL}$ of $0.2 \mathrm{M} \mathrm{NH}_{4} \mathrm{OH}$ at room temperature. After about 1 hour of coagulation, the precipitate was separated from the mother solution by filtration, carefully washed with cold water, and dried in a desiccator over $\mathrm{KOH}$ pellets. The compound was identified by gravimetric analysis (calcination to $\mathrm{Cr}_{2} \mathrm{O}_{3}$ at $\sim 800^{\circ} \mathrm{C}$ ) and by $\mathrm{x}$-ray powder diffractometry.

To prepare amorphous $\mathrm{Cr}$ (III) hydroxide (compounds II through IX), 10-20 mmoles of the selected chromium(III) salt were added to a small excess of $0.5 \mathrm{M} \mathrm{NH} 4 \mathrm{OH}$, and the precipitate formed was coagulated about one hour on a boiling water bath. The precipitate then was separated from the mother solution by centrifugation, washed two or three times with water, and transferred as a 3-M NaOH suspension into a Teflon test tube. The test tube was placed into a stainless steel autoclave and kept at the selected aging temperature for 15 or 20 hours. After heating, the solid phase was cooled, centrifuged from the mother liquor, washed by water until the solution phase had $\mathrm{pH}<9$, and dried in an $\mathrm{N}_{2}$ or $\mathrm{Ar}$ flow (to avoid the partial oxidation of $\mathrm{Cr}$ (III) by atmospheric oxygen). The final product was analyzed gravimetrically (by calcination to $\mathrm{Cr}_{2} \mathrm{O}_{3}$ at $\sim 800^{\circ} \mathrm{C}$ followed by weighing) and characterized by $\mathbb{R}$ spectroscopy, $\mathrm{x}$-ray powder diffractometry and, in some cases, particle size distribution by the SAXS technique. The hygroscopicities of the products were estimated by the measurement of the weight change of samples kept in desiccators over dry $\mathrm{KOH}$ and $25 \% \mathrm{H}_{2} \mathrm{SO}_{4}$ (1.7 and 14.6 torr, respectively, water vapor pressure at $20^{\circ} \mathrm{C}$ compared with 17.4 torr over pure water).

Chromium(III) mixed hydroxides or spinel phases containing $\mathrm{Fe}(\mathrm{III}), \mathrm{Fe}(\mathrm{II})$, or $\mathrm{Ni}(\mathrm{II})$, were prepared by the slow addition of initial solutions containing mixed $\mathrm{Cr}$ (III) nitrate and the respective other metal salts, in the 2:1 mole ratio, to a small excess of boiling $0.25 \mathrm{M} \mathrm{NaOH}$. The precipitates were coagulated for about 30 minutes and then treated in the same way as in the case of the $\mathrm{Cr}$ (III) hydroxides. The final products were analyzed gravimetrically following calcination at $800^{\circ} \mathrm{C}$ and, in the case of iron

Table 2.1. $\mathrm{Cr}$ (III) Compound Preparation for Dissolution Testing

\begin{tabular}{|c|c|c|c|c|}
\hline \multirow{2}{*}{$\begin{array}{l}\text { Compound } \\
\text { Number }\end{array}$} & \multirow[b]{2}{*}{ Composition } & \multirow[b]{2}{*}{ Precursors $^{(a)}$} & \multicolumn{2}{|c|}{ Coagulation } \\
\hline & & & Temperature, ${ }^{\circ} \mathrm{C}$ & Time, hr \\
\hline $\mathrm{I}$ & $\mathrm{Cr}(\mathrm{OH})_{3} \cdot 3 \mathrm{H}_{2} \mathrm{O}$ & $\bar{A}$ & 20 & 1 \\
\hline II & $\mathrm{Cr}_{2} \mathrm{O}_{3} \cdot 4 \mathrm{H}_{2} \mathrm{O}$ & B & 100 & 15 \\
\hline III & $\mathrm{Cr}_{2} \mathrm{O}_{3} \cdot 3.8 \mathrm{H}_{2} \mathrm{O}$ & $\mathrm{A}$ & 100 & 20 \\
\hline IV & $\mathrm{Cr}_{2} \mathrm{O}_{3} \cdot 4 \mathrm{H}_{2} \mathrm{O}$ & $\mathbf{C}$ & 100 & 20 \\
\hline $\mathrm{V}$ & $\mathrm{Cr}_{2} \mathrm{O}_{3} \cdot 2.9 \mathrm{H}_{2} \mathrm{O}$ & $\bar{A}$ & 150 & 20 \\
\hline $\mathrm{VI}$ & $\mathrm{Cr}_{2} \mathrm{O}_{3} \cdot 2.4 \mathrm{H}_{2} \mathrm{O}$ & $\mathrm{A}$ & 200 & 20 \\
\hline VII & $\mathrm{Cr}_{2} \mathrm{O}_{3} \cdot 2.35 \mathrm{H}_{2} \mathrm{O}$ & B & 250 & 20 \\
\hline VIII & $\mathrm{Cr}_{2} \mathrm{O}_{3} \cdot 2.3 \mathrm{H}_{2} \mathrm{O}$ & $\mathrm{A}$ & 250 & 20 \\
\hline IX & $\mathrm{Cr}_{2} \mathrm{O}_{3} \cdot 2.7 \mathrm{H}_{2} \mathrm{O}$ & A & 250 & 20 \\
\hline $\bar{X}$ & $\mathrm{NiCr}_{2} \mathrm{O}_{4} \cdot 5 \mathrm{H}_{2} \mathrm{O}$ & $D+2 A$ & 100 & 25 \\
\hline $\mathrm{XI}$ & $\mathrm{NiCl}_{2} \mathrm{O}_{4} \cdot 4 \mathrm{H}_{2} \mathrm{O}$ & $D+2 A$ & 200 & 20 \\
\hline XII & $\mathrm{Fe}_{0.67} \mathrm{Cr}_{1.33} \mathrm{O}_{3} \cdot 2 \mathrm{H}_{2} \mathrm{O}$ & $E+2 A$ & 100 & 20 \\
\hline XIII & $\mathrm{Fe}_{0.67} \mathrm{Cr}_{1.33} \mathrm{O}_{3} \cdot 2 \mathrm{H}_{2} \mathrm{O}$ & $E+2 A$ & 200 & 20 \\
\hline XIV & $\mathrm{FeCr}_{2} \mathrm{O}_{4.25} \cdot 3 \mathrm{H}_{2} \mathrm{O}$ & $\mathrm{F}+2 \mathrm{~A}$ & 100 & 20 \\
\hline 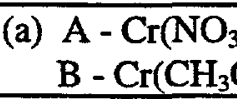 & $\begin{array}{l}\mathrm{C}-\mathrm{CrCl}_{3} \cdot 6 \\
\mathrm{D}-\mathrm{Ni}(\mathrm{NO}\end{array}$ & $\mathrm{H}_{2} \mathrm{O}$ & $\begin{array}{l}\mathrm{E}-\mathrm{Fe}\left(\mathrm{NO}_{3}\right)_{3} \cdot 9 \mathrm{H}_{2} \\
\mathrm{~F}-\mathrm{FeSO} \mathrm{SO}_{4} \cdot 7 \mathrm{H}_{2} \mathrm{O}\end{array}$ & \\
\hline
\end{tabular}


compounds, by iodometric titration to determine $\mathrm{Fe}$ (II):Fe(III) concentrations after dissolving solid samples in $2 \mathrm{M} \mathrm{HCl}$. The analytical results showed that iron(II) chromite suffered $\sim 50 \% \mathrm{Fe}$ (II) oxidation during its separation from the mother solution and subsequent drying. Therefore this product is considered to be a mixture of $\mathrm{Fe}(\mathrm{II})$ and $\mathrm{Fe}$ (III) compounds [that is, $\mathrm{FeCr}_{2} \mathrm{O}_{4} \cdot \mathrm{xH}_{2} \mathrm{O}$ and 1.5 $\mathrm{Fe}_{0.67} \mathrm{Cr}_{1.33} \mathrm{O}_{3} \cdot \mathrm{yH}_{2} \mathrm{O}$ or $\mathrm{FeCr}_{2} \mathrm{O}_{4.25} \cdot 3 \mathrm{H}_{2} \mathrm{O}$ (compound XIV) and is listed in Table 2.1 with the other solid phases prepared for testing.

\subsection{Characteristics of the Chromium Solid Phases}

As expected, $\mathrm{x}$-ray powder diffractometry showed that the $\mathrm{Cr}(\mathrm{III})$ hydroxide compound I, precipitated in dilute $\mathrm{NH}_{4} \mathrm{OH}$ at room temperature, was crystalline with a bayerite structure (Figure 2.1). All other $\mathrm{Cr}$ (III) hydroxide compounds II-IX were practically amorphous (representative diffractograms given in Figure 2.2). Only very diffuse reflections, primarily for materials aged at elevated temperatures, were present in the diffractograms. It is difficult to attribute these reflections confidently to known crystalline $\mathrm{Cr}$ (III) compounds; however, compounds II-IX likely contain very fine crystallites of $\alpha$ $\mathrm{CrOOH}$ and $\gamma$-CrOOH. This supposition is based on the observation of diffuse, but discernable, $\mathrm{x}$-ray reflections at $13.5,37.3,47.4$ and 61.2-62.2 degrees $2 \theta$, corresponding, respectively, to d spacings of 6.5 , 2.41, 1.92, and 1.51-1.48 $\AA$. In comparison, the $\alpha-\mathrm{CrOOH}$ diffraction pattern contains intense reflections at 2.41 and $1.49 \AA ; \gamma-\mathrm{CrOOH}$ shows strong reflections at 6.5, 1.97, and 1.49 $\AA$ [Ryabin et al. 1981]. The very small crystallite sizes of the prepared $\mathrm{Cr}$ (III) hydroxides were confirmed by the SAXS technique. As seen in Figure 2.3, most of the material consists of particles with diameter ( $2 \mathrm{R})$ less than $3 \mathrm{~nm}(30 \AA)$.
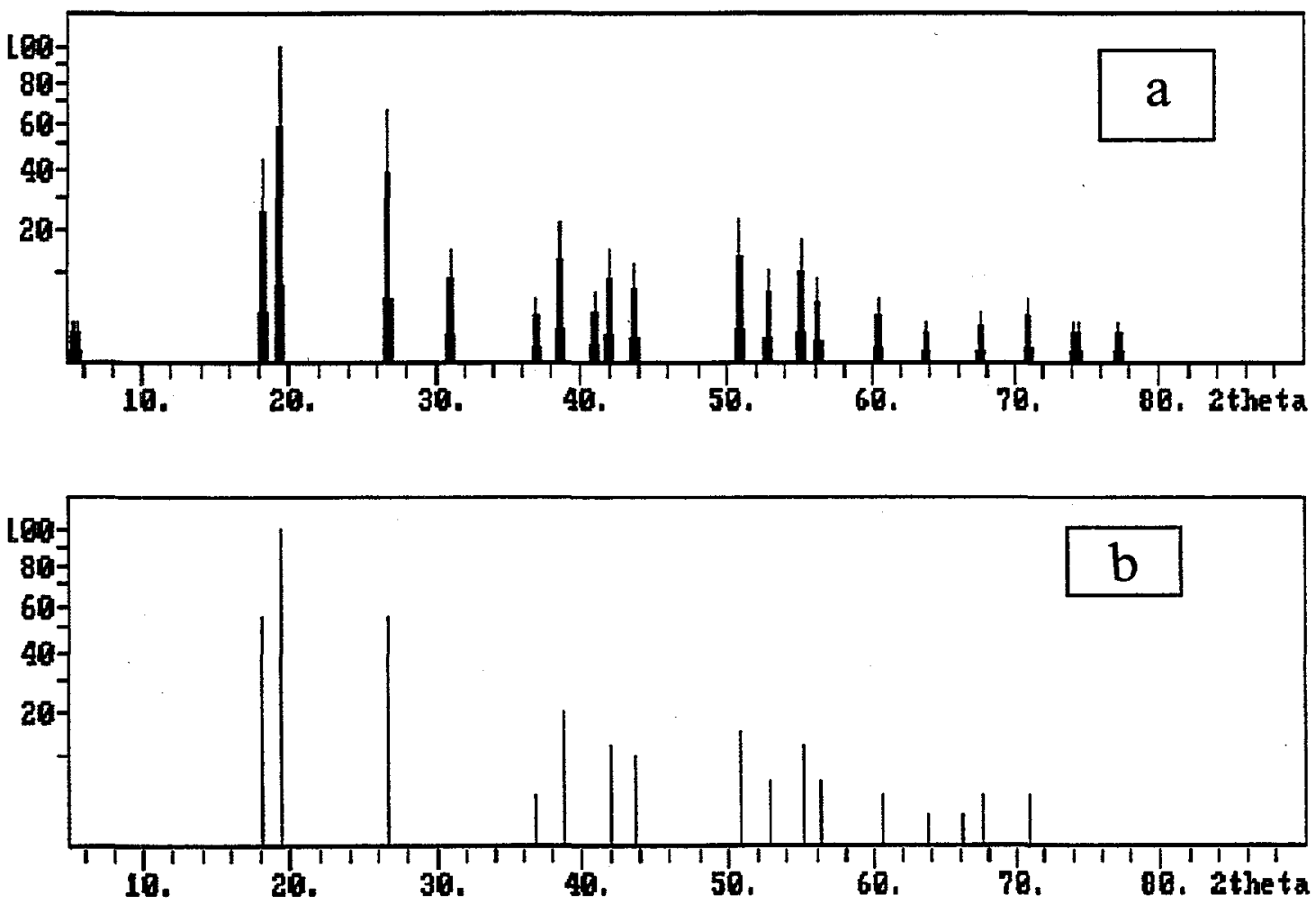

Figure 2.1. Diffractogram of $\mathrm{Cr}(\mathrm{OH})_{3} \cdot 3 \mathrm{H}_{2} \mathrm{O}$

a - compound I

b - Cr(III) hydroxide, bayerite structure [JCPDS file 16-817]

(Joint Committee on Powder Diffraction Standards) 

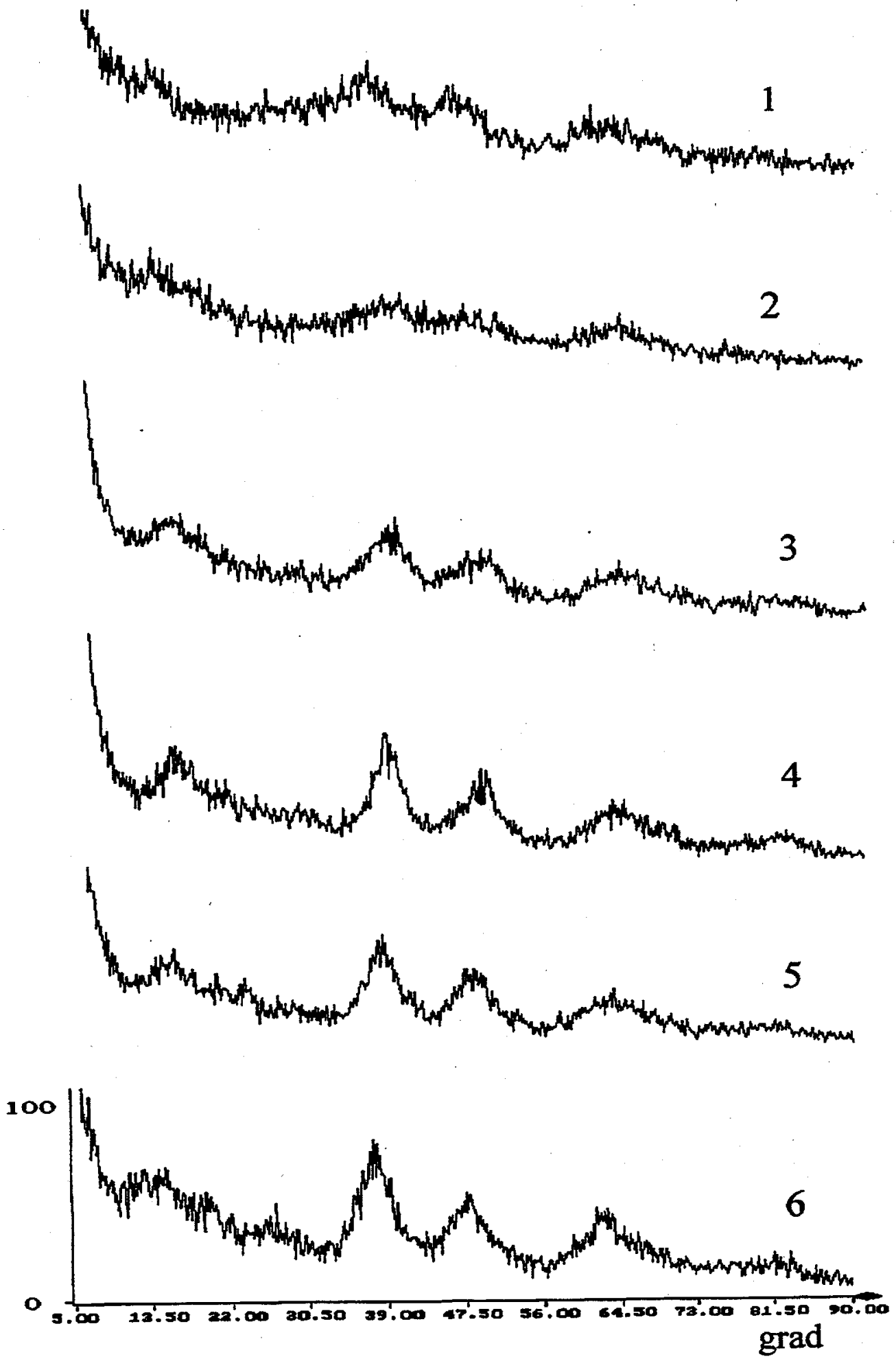

Figure 2.2. Diffractograms of $\mathrm{Cr}$ (III) hydroxide compounds: 1 - II; 2 - III; 3 - V; 4 - VI; 5 - IX; 6 - VII (in order of increasing peak intensity) 


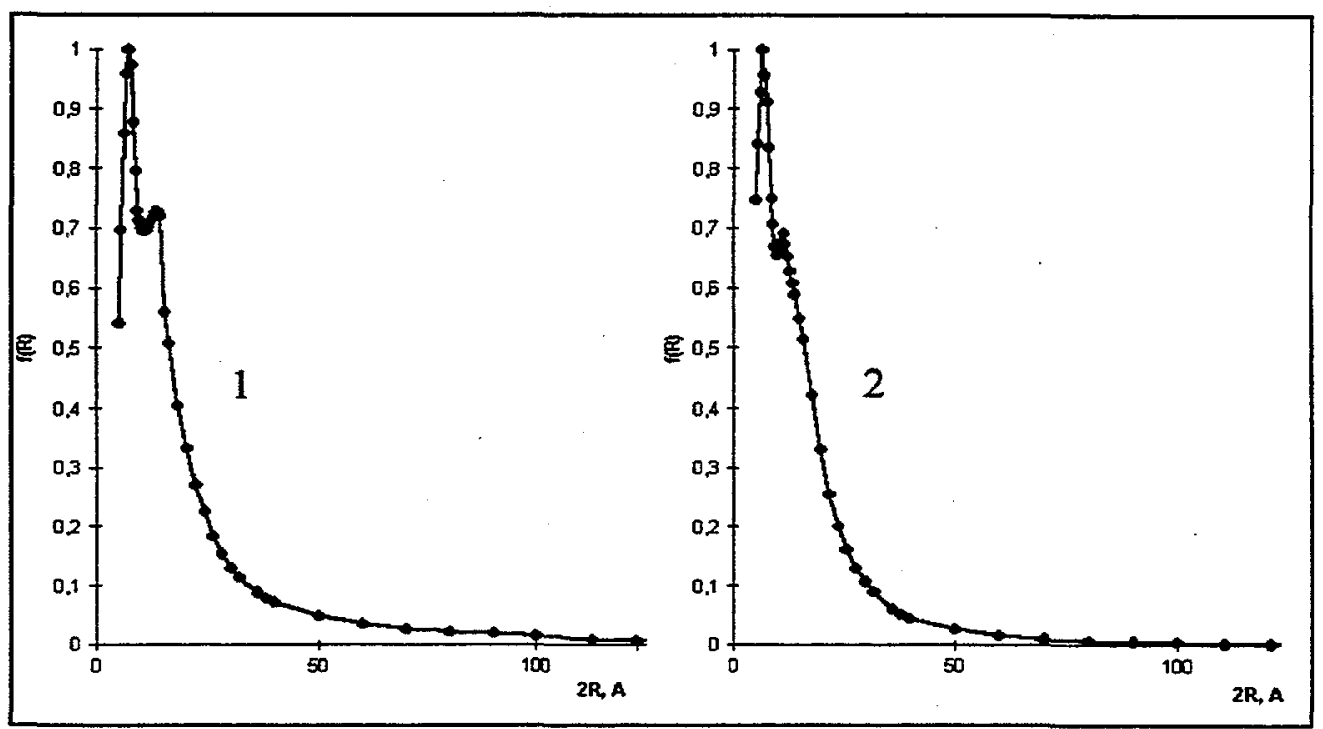

Figure 2.3. Volumetric Particle Size Distribution for $\mathrm{Cr}$ (III) Hydroxide Compounds:

$$
1-\mathrm{V} ; 2 \text { - III }
$$

The IR spectra (Figure 2.4) of aged $\mathrm{Cr}(\mathrm{III})$ hydroxides (compounds II-IX) are similar to those described in the literature for $\mathrm{Cr}$ (III) hydroxide [Ratnasamy and Leonard 1972; Simonova 1973]. The spectra clearly display bands in the ranges $500-600,1600-1650$ and $3400-3600 \mathrm{~cm}^{-1}$ attributable to deformation vibrations of $\mathrm{Cr}-\mathrm{O}$ bonds and the deformation and valent vibrations of water, respectively. Based on the spectra, it is difficult to confirm the presence or absence of $\mathrm{CrOOH}$ phases in $\Pi-\mathrm{IX}$. The $\mathrm{CrOOH}$ phases are characterized by a weak and broad band at $-1600 \mathrm{~cm}^{-1}$ [Snyder and Ibers 1962 ; Claydon et al. 1975] that would be obscured by the overlying bands from $\mathrm{Cr}$ (III) hydroxide.

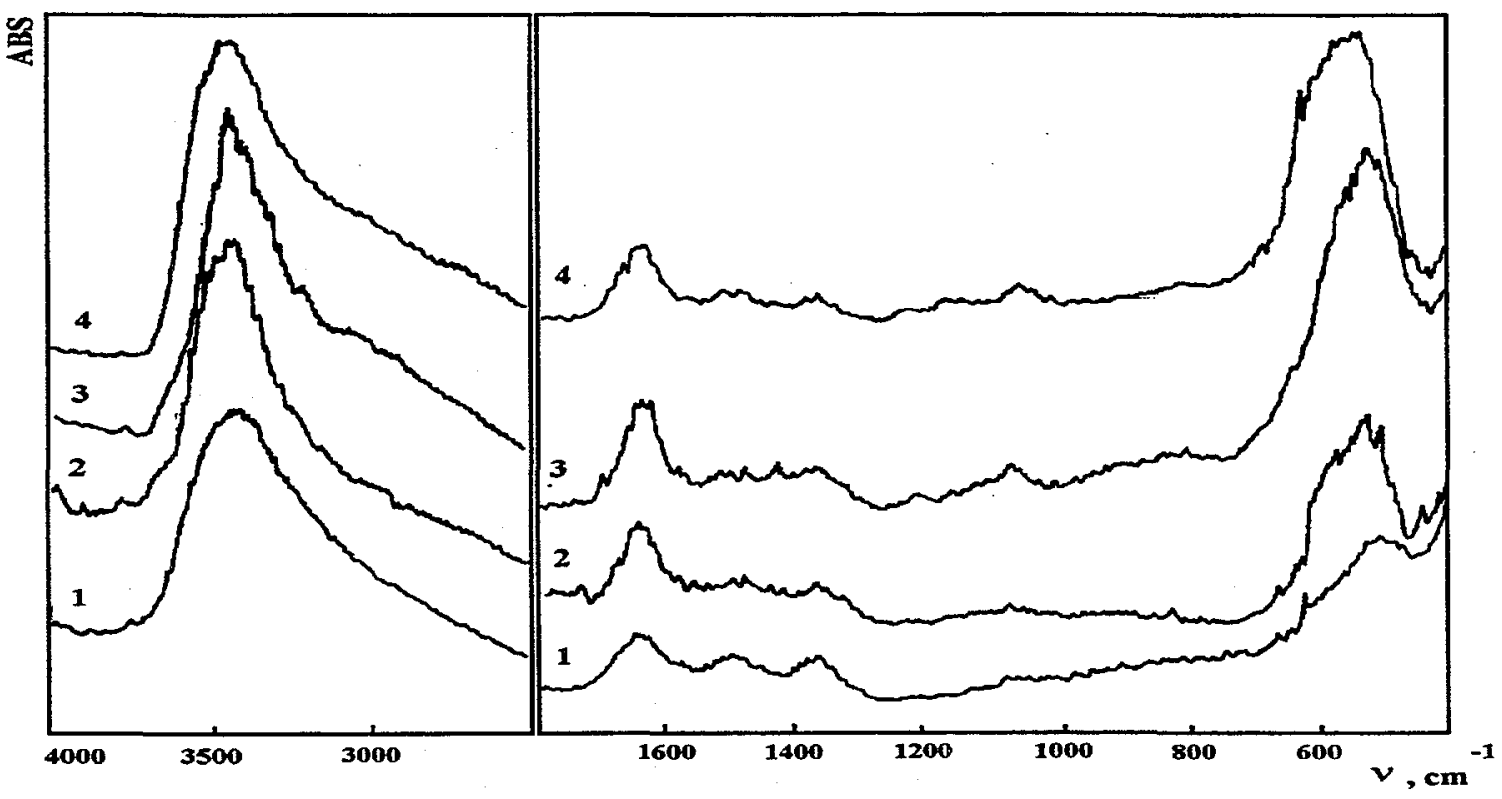

Figure 2.4. Infrared Spectra of Some $\mathrm{Cr}$ (III) Hydroxide Compounds: 1 - II; 2 - V; 3 - VI; 4 - VII 
The $\mathrm{Ni}(\mathrm{II}), \mathrm{Fe}(\mathrm{II})$, and $\mathrm{Fe}$ (III) chromites (compounds X-XIV) also were largely amorphous (Figure 2.5). Their IR spectra, shown in Figures 2.6 and 2.7, seem to confirm the presence of spinel-type chromites [Yur'eva et al. 1968; Preudhomme and Tarte 1971] for compounds X, XI, and XIV.

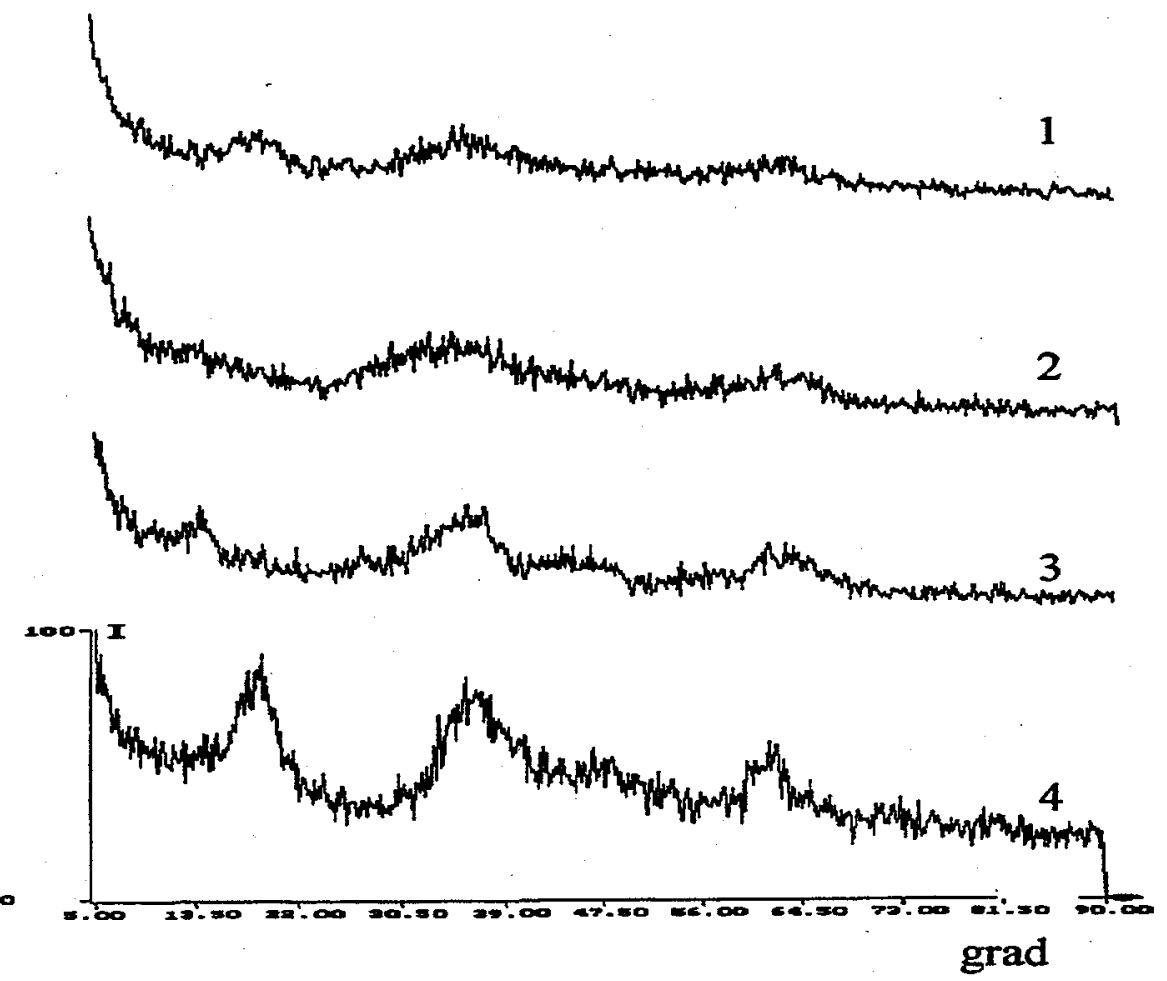

Figure 2.5. Diffractograms of $\mathrm{Cr}$ (III) Compounds:

1 - XIV; 2 - XII; 3 - XIII; 4 - X

(in order of increasing peak intensity)

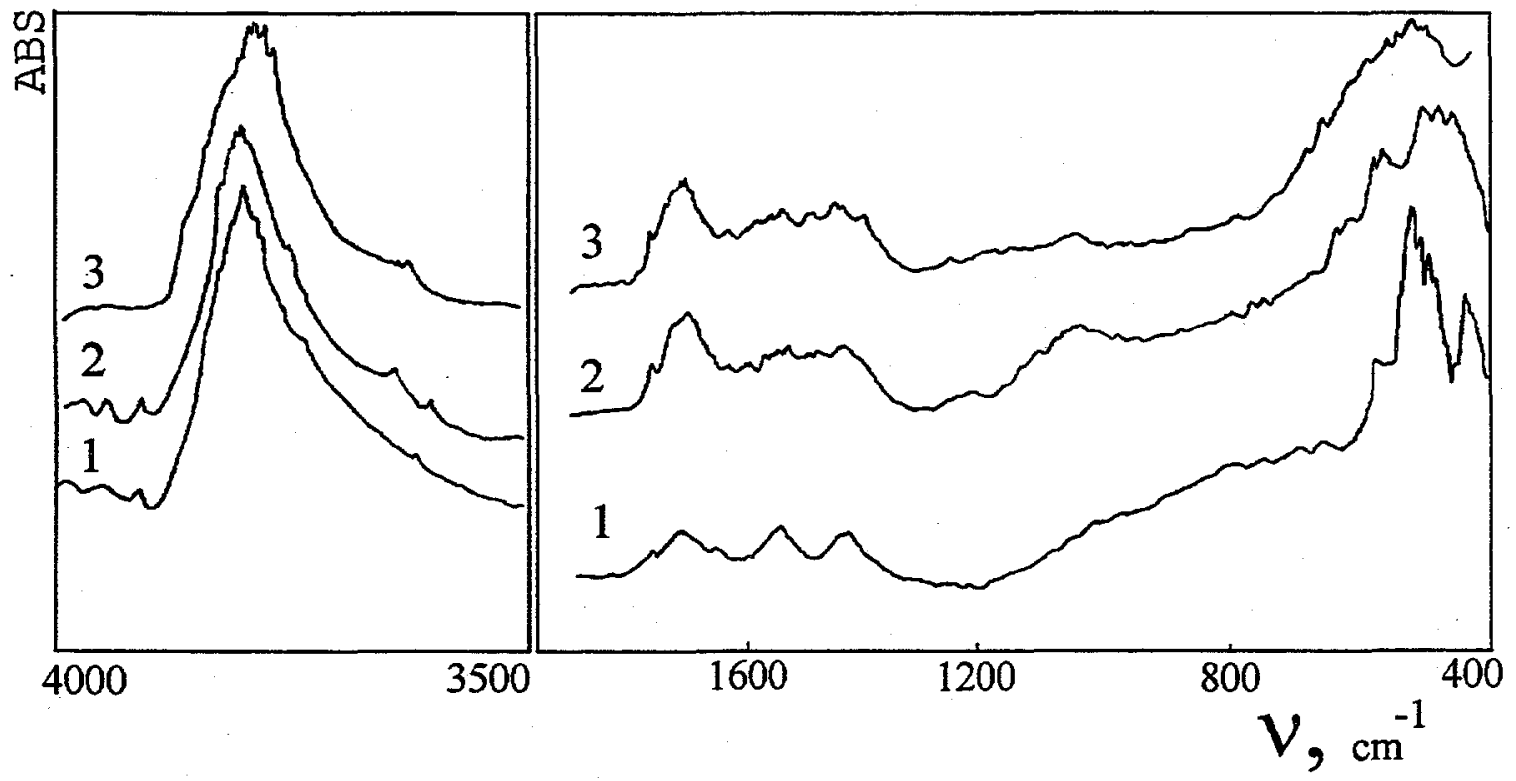

Figure 2.6. Infrared Spectra of Some $\mathrm{Cr}(\mathrm{III}) / \mathrm{Fe}(\mathrm{III})$ Hydroxide Compounds: 1 - XIV; 2 - XII; 3 - XIII 


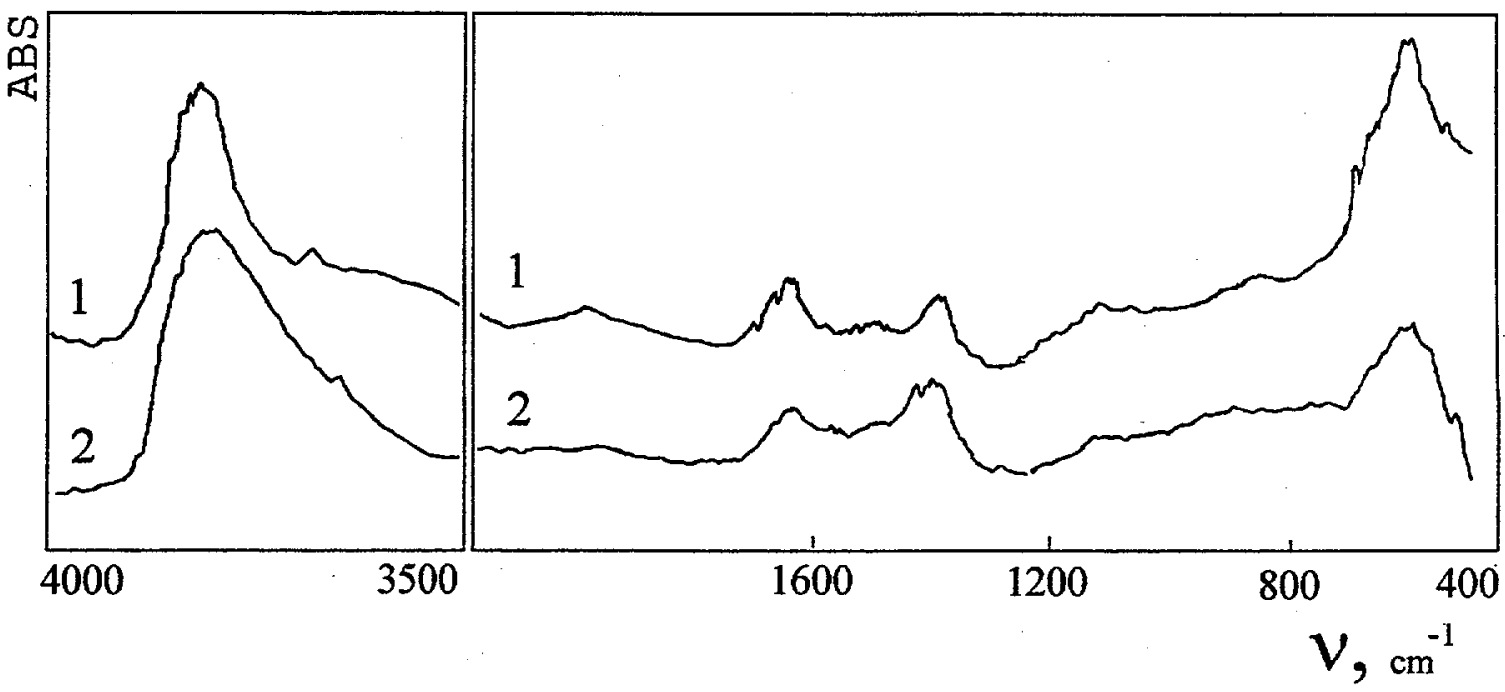

Figure 2.7. Infrared Spectra of $\mathrm{NiCr}_{2} \mathrm{O}_{4} \cdot \mathrm{nH}_{2} \mathrm{O}$ Compounds:

$1-X ; 2-X I$

The $\mathrm{Cr}$ (III) hydroxide compounds have variable water content (Table 2.2). The water contents correlate qualitatively with the aging temperatures used in the compound preparation and with the apparent crystallinities indicated by the respective compounds' diffractograms (Figure 2.2). The water contents also depend on the drying conditions (Table 2.2). Separate tests showed that the water loss of the amorphous $\mathrm{Cr}$ (III) hydroxides is reversible. The hygroscopic properties of the compounds must be considered in interpreting the dissolution test characteristics.

Table 2.2. Hygroscopic Properties of $\mathrm{Cr}$ (III) Compounds

\begin{tabular}{|c|c|c|c|c|c|}
\hline \multirow{2}{*}{$\begin{array}{l}\text { Compound } \\
\text { Number }\end{array}$} & \multirow{2}{*}{$\begin{array}{c}\text { Compound } \\
\text { Composition }\end{array}$} & \multirow{2}{*}{$\begin{array}{c}\text { Aging } \\
\text { Temperature, } \\
{ }^{\circ} \mathrm{C} \\
\end{array}$} & \multicolumn{2}{|c|}{$\begin{array}{l}\text { Hydrate number, } \mathrm{x}, \\
\text { after drying over }\end{array}$} & \multirow[b]{2}{*}{$\Delta \mathrm{x}$} \\
\hline & & & $\mathrm{KOH}$ & $25 \% \mathrm{H}_{2} \mathrm{SO}_{4}$ & \\
\hline II & $\mathrm{Cr}_{2} \mathrm{O}_{3} \cdot 4 \mathrm{H}_{2} \mathrm{O}$ & 100 & 4.0 & 5.15 & 1.15 \\
\hline III & $\mathrm{Cr}_{2} \mathrm{O}_{3} \cdot 3.8 \mathrm{H}_{2} \mathrm{O}$ & 100 & 3.8 & 4.8 & 1.0 \\
\hline IV & $\mathrm{Cr}_{2} \mathrm{O}_{3} \cdot 4 \mathrm{H}_{2} \mathrm{O}$ & 100 & 4.0 & 5.1 & 1.1 \\
\hline $\mathrm{V}$ & $\mathrm{Cr}_{2} \mathrm{O}_{3} \cdot 2.9 \mathrm{H}_{2} \mathrm{O}$ & 150 & 2.9 & 4.4 & 1.5 \\
\hline VI & $\mathrm{Cr}_{2} \mathrm{O}_{3} \cdot 2.4 \mathrm{H}_{2} \mathrm{O}$ & 200 & 2.4 & 3.8 & 1.4 \\
\hline VII & $\mathrm{Cr}_{2} \mathrm{O}_{3} \cdot 2.35 \mathrm{H}_{2} \mathrm{O}$ & 250 & 2.35 & 3.8 & 1.45 \\
\hline VIII & $\mathrm{Cr}_{2} \mathrm{O}_{3} \cdot 2.3 \mathrm{H}_{2} \mathrm{O}$ & 250 & 2.3 & 3.35 & 1.05 \\
\hline IX & $\mathrm{Cr}_{2} \mathrm{O}_{3} \cdot 2.7 \mathrm{H}_{2} \mathrm{O}$ & 250 & 2.7 & 4.0 & 1.3 \\
\hline $\mathrm{X}$ & $\mathrm{NiC}_{2} \mathrm{O}_{4} \cdot 5 \mathrm{H}_{2} \mathrm{O}$ & 100 & 5.0 & 6.6 & 1.6 \\
\hline XI & $\mathrm{NiCr}_{2} \mathrm{O}_{4} \cdot 4 \mathrm{H}_{2} \mathrm{O}$ & 200 & 4.0 & 5.7 & 1.7 \\
\hline XII & $\mathrm{Fe}_{0.67} \mathrm{Cr}_{1.33} \mathrm{O}_{3} \cdot 2 \mathrm{H}_{2} \mathrm{O}$ & 100 & 2.0 & 2.9 & 0.9 \\
\hline XIII & $\mathrm{Fe}_{0.67} \mathrm{Cr}_{1.33} \mathrm{O}_{3} \cdot 2 \mathrm{H}_{2} \mathrm{O}$ & 200 & 2.0 & 3.3 & 1.3 \\
\hline XIV & $\mathrm{FeCr}_{2} \mathrm{O}_{4.25} \cdot 3 \mathrm{H}_{2} \mathrm{O}$ & 100 & 3.0 & 4.7 & 1.7 \\
\hline
\end{tabular}




\subsection{Experimental Procedure for Tests with Oxygen}

The experimental investigation of the oxidative dissolution of $\mathrm{Cr}$ (III) compounds was performed using atmospheric air and pure oxygen at normal and elevated pressures. Tests to determine the initial reaction rate usually were performed by first bubbling oxygen or air at a slow rate through 5 or $10 \mathrm{~mL}$ of $\mathrm{NaOH}$ solution in a closed, thermostatted polyethylene reaction cell for 15-20 minutes at constant temperature. The cell contents then were agitated by a magnetic stirrer; the temperature was maintained at $\pm 2^{\circ} \mathrm{C}$. Experiments with oxygen at elevated pressures were performed in a special plastic vessel fitted with a manometer to measure pressure with an accuracy of $\pm 0.1 \mathrm{~atm}$. To avoid solution evaporation, the gas first was humidified by bubbling through a $\mathrm{NaOH}$ solution of the same concentration and temperature as used in the working cell. To remove the $\mathrm{CO}_{2}$ contained in air, the gas was passed through a column filled with $\mathrm{KOH}$ pellets.

After achieving temperature equilibrium, a measured quantity (usually 0.1 mmole) of a $\mathrm{Cr}$ (III) compound was added to the cell and the suspension agitated by magnetic stirring for 6-12 hours. Periodically (e.g., 1-2 hour intervals), samples of the suspension were withdrawn, mixed with $3 \mathrm{~mL}$ of water to quench the reaction, and centrifuged to separate the solid phase. The $\mathrm{Cr}(\mathrm{VI})$ solution concentration was determined by measuring light absorbence at $373 \mathrm{~nm}$. Using standard chromate solutions in $0.2-3 \mathrm{M} \mathrm{NaOH}$, the molar extinction coefficient, $\varepsilon$, of $\mathrm{CrO}_{4}{ }^{2-}$ at $373 \mathrm{~nm}$ was found to be $4850 \mathrm{M}^{-1} \mathrm{~cm}^{-1}$, in good agreement with related studies [4836 $\pm 20 \mathrm{M}^{-1} \mathrm{~cm}^{-1}$ at $372 \mathrm{~nm}$ (Rapko et al. 1997)]. It was confirmed that $\varepsilon$ is practically independent of $\mathrm{NaOH}$ concentration over the studied range.

Experiments to study long-term interaction of $\mathrm{Cr}(\mathrm{III})$ compounds with oxygen were performed by the same method with suspension samples taken for analysis infrequently. Suspension volumes and $\mathrm{NaOH}$ concentrations were periodically adjusted during the experiments to maintain alkali and chromium concentrations constant within $\pm 5 \%$.

\subsection{Experimental Procedure for Tests with Hydrogen Peroxide}

Tests on the kinetics of $\mathrm{Cr}$ (III) oxidation by hydrogen peroxide in alkaline solutions were usually conducted in this sequence: First, about 0.1 mmole of a $\mathrm{Cr}$ (III) compound was added to $5 \mathrm{~mL}$ of a standard $\mathrm{NaOH}$ solution in a thermostatted cell installed on a magnetic stirrer. In some cases, a known amount of catalyst was added to the $\mathrm{Cr}$ (III) compound suspension. After achieving thermal equilibrium ( 15 minutes), a measured amount of $\mathrm{H}_{2} \mathrm{O}_{2}$ was added to the suspension. Samples of the reaction mixture were withdrawn periodically. The samples were quickly diluted by water to quench the reaction, the solid phase separated by centrifugation, and the solution analyzed for chromate concentration by measurement of optical absorbence at $373 \mathrm{~nm}$.

To determine $\mathrm{H}_{2} \mathrm{O}_{2}$ consumption in the partial oxidation of $\mathrm{Cr}$ (III) compounds, a measured volume of $\mathrm{NaOH}$ solution was added to a known amount of the compound in a thermostatted cell. After achieving thermal equilibrium, $0.05-\mathrm{mL}$ aliquots of a standard solution of $\mathrm{H}_{2} \mathrm{O}_{2}$ were introduced every two to three minutes. The extent of reaction was determined by the disappearance of solid phase, in the case of $\mathrm{Cr}$ (III) hydroxides, or by the spectrophotometric determination of $\mathrm{Cr}(\mathrm{VI})$ concentration in the solution phase after its separation from the test solid phases by centrifugation. 


\subsection{Experimental Procedure for Tests with Persulfate}

Preliminary experiments showed that the rate of $\mathrm{Cr}(\mathrm{III})$ oxidation by $\mathrm{S}_{2} \mathrm{O}_{8}{ }^{2-}$ strongly depends on alkali concentration and temperature. In $40-70^{\circ} \mathrm{C}, 0.3-3 \mathrm{M} \cdot \mathrm{NaOH}$, the reactions proceed at rates convenient to measure by ordinary techniques. Such conditions were chosen for the primary tests. The tests usually were conducted by adding a known amount (usually $0.1-0.2$ mmole) of a $\mathrm{Cr}(\mathrm{III})$ compound to 2-5 mL of a standard $\mathrm{NaOH}$ solution in a thermostatted cell installed on a magnetic stirrer. After the $\sim 15$ minutes taken to achieve thermal equilibrium, a measured amount of $\mathrm{Na}_{2} \mathrm{~S}_{2} \mathrm{O}_{8}$ solution was added to the suspension. After that, samples of reaction mixture were withdrawn periodically. The samples were quickly diluted by water, separated from the solid phase by centrifugation, and analyzed for chromate by measurement of the absorbence at $373 \mathrm{~nm}$. Based on these results, the $\mathrm{Cr}(\mathrm{VI})$ concentrations were calculated as a function of time.

Special tests were performed to estimate the reaction stoichiometry under the tested conditions. In these tests, known amounts of $\mathrm{Cr}$ (III) hydroxide (compound II) were treated in $\mathrm{NaOH}$ solutions by different excess quantities of persulfate. The test durations were sufficient to permit completion of the reaction. Then the concentrations of $\mathrm{Cr}$ (VI) were determined in the final solutions or suspensions. The $\mathrm{Cr}(\mathrm{VI})$ yields were compared with the quantities of added $\mathrm{S}_{2} \mathrm{O}_{8}{ }^{2-}$ to determine reaction stoichiometry. 


\subsection{Oxidative Alkaline Dissolution of Chromium(III) Compounds by Gaseous Oxygen}

The primary objective of the tests to determine the initial $\mathrm{Cr}(\mathrm{III})$ oxidation rate by oxygen was to identify the optimum temperature and $\mathrm{NaOH}$ concentration to perform the process and to determine the effect of oxygen pressure on the reaction rate. Based on prior studies [Rapko 1998], these experiments were performed at $50-90^{\circ} \mathrm{C}$ using $0.2-5 \mathrm{M} \mathrm{NaOH}$.

\subsection{Tests with Atmospheric Oxygen}

Preliminary tests showed that the $\mathrm{Cr}$ (III) hydroxide oxidation rate by atmospheric oxygen is slow and independent of the intensity of gas bubbling (used in combination with magnetic stirring to introduce the gas to solution). Thus it is most likely that $\mathrm{Cr}$ (III) reacts under these conditions only with dissolved oxygen and that the rates of oxygen supply to the solution phase in the present tests were higher than those of the ensuing $\mathrm{Cr}(\mathrm{III})$ oxidation.

Typical kinetic curves on the short-term reaction of $\mathrm{Cr}$ (III) hydroxides with atmospheric oxygen in alkaline suspensions are presented in Figure 3.1. The $\mathrm{Cr}$ (VI) concentration increases linearly with time. The kinetic curve slopes may be used to estimate the initial reaction rates, $V_{0}$, under the given conditions.

As seen in Table 3.1, the initial reaction rates, $\mathrm{V}_{\mathrm{o}}$, increase strongly with increasing $\mathrm{NaOH}$ concentration. To a first approximation, $\mathrm{V}_{0}$ is proportional to $\mathrm{NaOH}$ concentration, although this dependence actually is somewhat more complex.

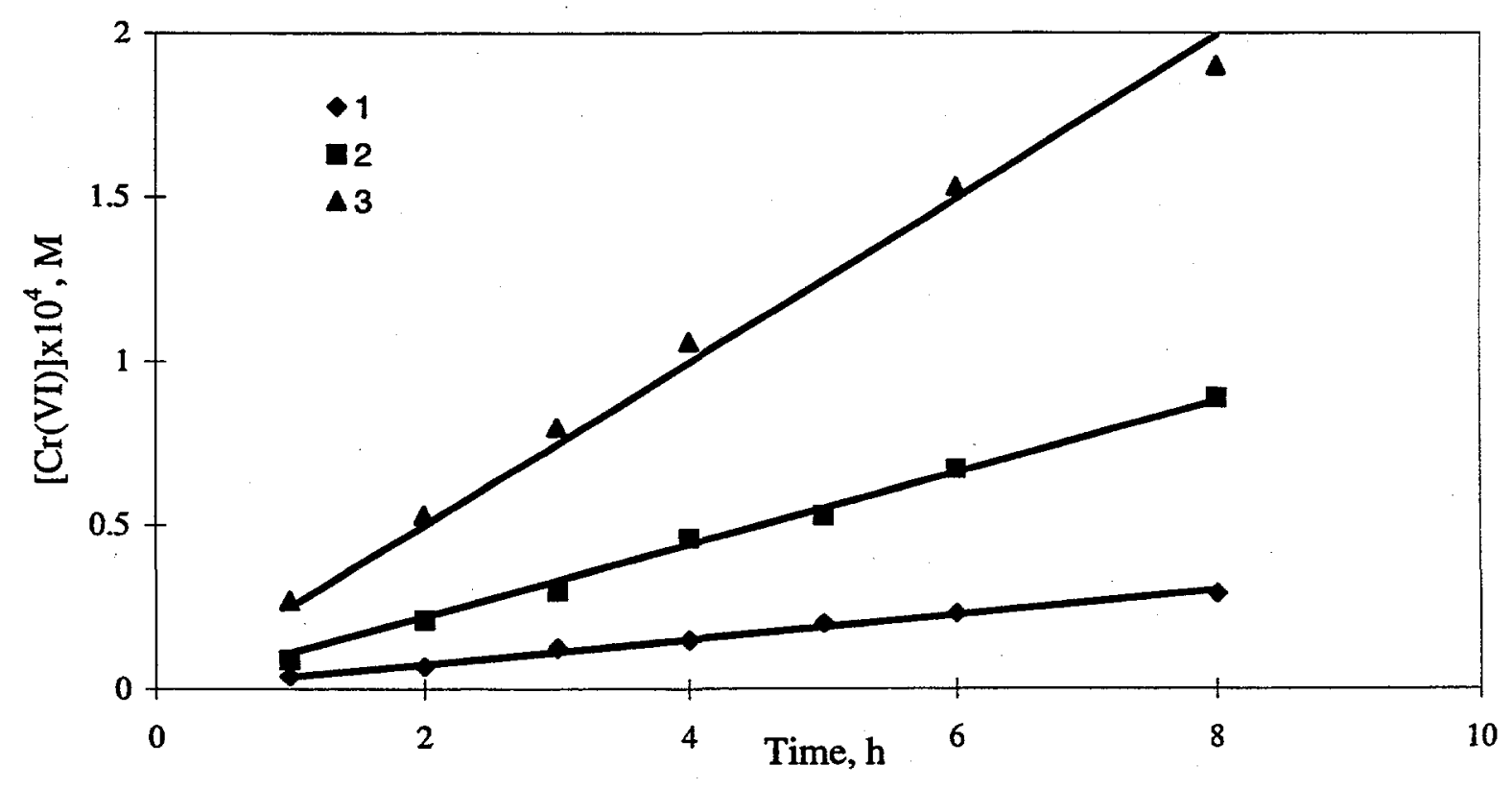

Figure 3.1. Kinetics of $0.02 \mathrm{M} \mathrm{Cr}$ (III) Hydroxide (compound VIII) Oxidation by Atmospheric Oxygen at $70^{\circ} \mathrm{C}:[\mathrm{NaOH}], \mathrm{M}: 1-1 ; 2-3 ; 3-5$ 
Table 3.1. Effect of $\mathrm{NaOH}$ Concentration on the Oxidation Rate of $0.02 \mathrm{M} \mathrm{Cr}$ (III) Hydroxide Suspensions by Atmospheric Oxygen at $70^{\circ} \mathrm{C}$

\begin{tabular}{|c|c|c|c|c|}
\hline \multirow{2}{*}[\mathrm{NaOH}]{, $\mathrm{M}$} & \multicolumn{4}{|c|}{$\mathrm{V}_{\mathrm{o}}$, moles/liter-hour, for different $\mathrm{Cr}$ (III) compounds } \\
\cline { 2 - 5 } & $\mathrm{II}\left(100^{\circ} \mathrm{C}\right.$ aging $)$ & $\mathrm{V}\left(150^{\circ} \mathrm{C}\right.$ aging $)$ & $\mathrm{VI}\left(200^{\circ} \mathrm{C}\right.$ aging $)$ & $\mathrm{VIII}\left(250^{\circ} \mathrm{C}\right.$ aging $)$ \\
\hline 0.2 & $0.2 \times 10^{-5}$ & - & - & - \\
\hline 1.0 & $0.6 \times 10^{-5}$ & $0.5 \times 10^{-5}$ & $0.4 \times 10^{-5}$ & $0.3 \times 10^{-5}$ \\
\hline 2.0 & $1.4 \times 10^{-5}$ & $1.0 \times 10^{-5}$ & - & - \\
\hline 3.0 & $3.0 \times 10^{-5}$ & $2.1 \times 10^{-5}$ & $1.2 \times 10^{-5}$ & $1.2 \times 10^{-5}$ \\
\hline 4.0 & $6.8 \times 10^{-5}$ & $2.5 \times 10^{-5}$ & - & - \\
\hline 5.0 & - & - & $3.1 \times 10^{-5}$ & $2.2 \times 10^{-5}$ \\
\hline
\end{tabular}

The initial rate of $\mathrm{Cr}$ (III) hydroxide oxidation depends also on temperature, but the rate is practically independent of $\mathrm{Cr}$ (III) solid compound concentration in the range 0.01 to $0.1 \mathrm{M}$ (Table 3.2). The dependence of $V_{0}$ on temperature is linear in Arrhenius coordinates (Figure 3.2), and the slope corresponds to a formal activation energy, $E_{a}$, of about $22 \mathrm{~kJ} /$ mole. This relatively low $E_{a}$ is explained by the opposing effects of increasing temperature, which increased the reaction rate but decreased the solubility of oxygen in alkaline solution. Thus the increase in rate of $\mathrm{Cr}(\mathrm{III})$ reaction with oxygen caused by increasing temperature is offset to some extent by the concomitant decrease in rate caused by the decreased concentration of dissolved $\mathrm{O}_{2}$.

The absence of an effect of $\mathrm{Cr}(\mathrm{III})$ hydroxide concentration in alkaline suspensions on $\mathrm{V}_{\mathrm{o}}$ undoubtedly shows that the $\mathrm{Cr}(\mathrm{II})$ oxidation by oxygen proceeds through the preliminary dissolution of the solid phase. Because of the low reaction rate, a constant $\mathrm{Cr}$ (III) concentration is available in alkaline solution independent of the amount of solid phase in suspension. Thus, the following steps represent the mechanism of the reaction:

$$
\begin{gathered}
\mathrm{Cr}_{2} \mathrm{O}_{3} \cdot \mathrm{nH}_{2} \mathrm{O}_{(\mathrm{s})} \leftrightarrow \mathrm{Cr}(\mathrm{III})_{(\mathrm{aq})} \\
\mathrm{O}_{2(\mathrm{~g})} \leftrightarrow \mathrm{O}_{2(\mathrm{aq})} \\
\mathrm{Cr}(\mathrm{III})_{(\mathrm{aq})}+\mathrm{O}_{2 \text { (aq) }} \rightarrow \mathrm{Cr}(\mathrm{VI})_{(\mathrm{aq})}
\end{gathered}
$$

\begin{tabular}{|c|c|c|c|}
\hline Compound Number & {$[\mathrm{Cr}(\mathrm{III})]_{0}, \mathrm{M}$} & $\mathrm{T},{ }^{\circ} \mathrm{C}$ & $\mathrm{V}_{\mathrm{o}}$, moles/liter-hour \\
\hline \multirow[t]{3}{*}{ II } & 0.01 & \multirow[t]{3}{*}{70} & $2.7 \times 10^{-5}$ \\
\hline & 0.02 & & $3.0 \times 10^{-5}$ \\
\hline & 0.10 & & $2.9 \times 10^{-5}$ \\
\hline \multirow[t]{3}{*}{ II } & \multirow[t]{3}{*}{0.02} & 45 & $1.6 \times 10^{-5}$ \\
\hline & & 60 & $2.5 \times 10^{-5}$ \\
\hline & & 80 & $3.6 \times 10^{-5}$ \\
\hline \multirow[t]{5}{*}{$\bar{V}$} & \multirow[t]{5}{*}{0.02} & 60 & $1.4 \times 10^{-5}$ \\
\hline & & 70 & $1.8 \times 10^{-5}$ \\
\hline & & 75 & $1.8 \times 10^{-5}$ \\
\hline & & 80 & $2.2 \times 10^{-5}$ \\
\hline & & 90 & $2.7 \times 10^{-5}$ \\
\hline
\end{tabular}

Table 3.2. Effect of Temperature and $\mathrm{Cr}$ (III) Compound Initial Concentration on $\mathrm{Cr}$ (III) Hydroxide Oxidation by Atmospheric Oxygen in $3 \mathrm{M} \mathrm{NaOH}$ 


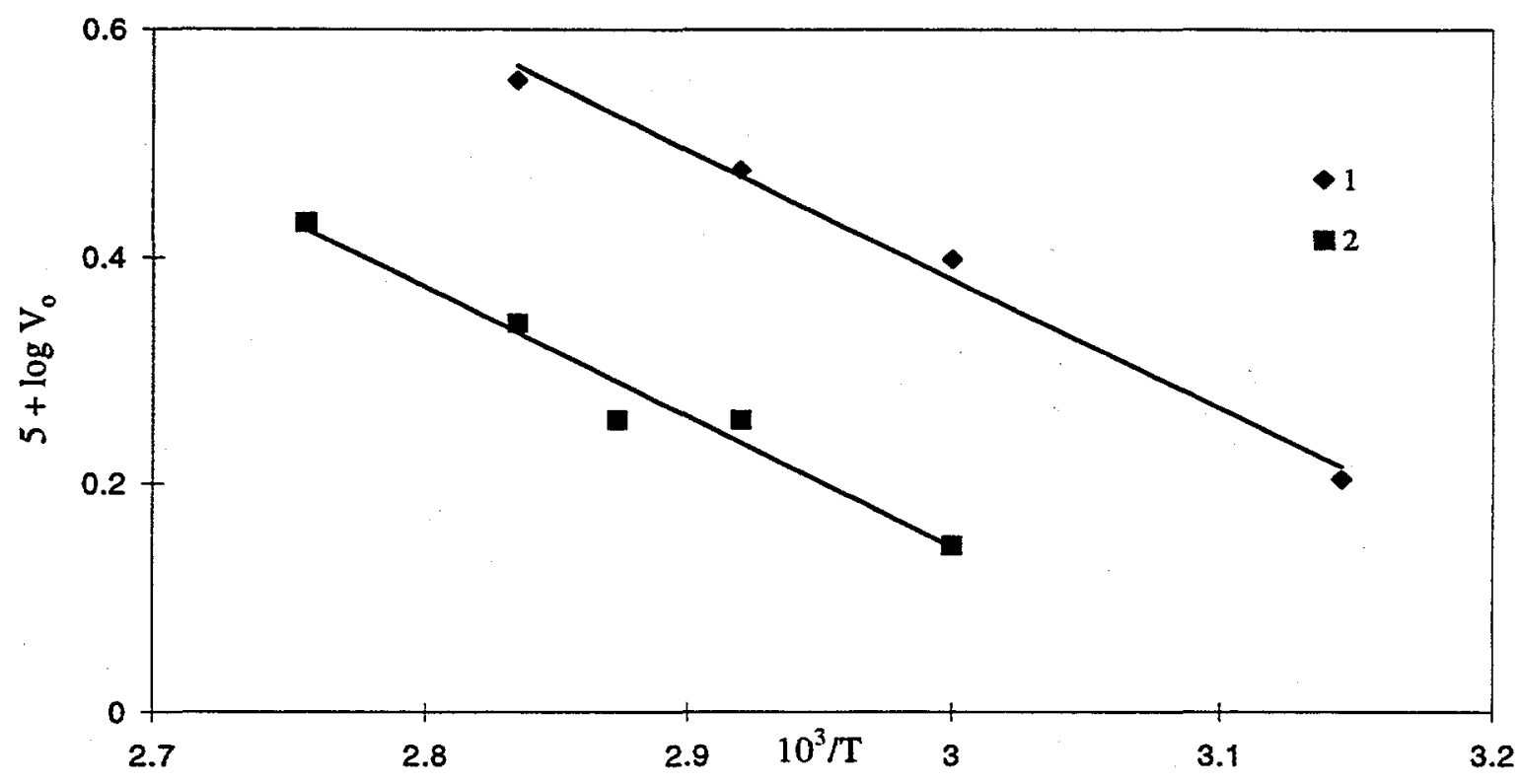

Figure 3.2. Effect of Temperature on Rate of $\mathrm{Cr}$ (III) Hydroxide Oxidation by Atmospheric Oxygen in $3 \mathrm{M} \mathrm{NaOH}$ : 1 - compound II; 2 - compound $\mathrm{V}$

The temperature of $\mathrm{Cr}$ (III) hydroxide aging has little influence on the reaction rate. A small tendency towards decreasing $\mathrm{V}_{\mathrm{o}}$ with increase in the temperature of the hydroxides' hydrothermal treatment is noted and $\mathrm{V}_{0}$ distinctly increases with increasing water content in the $\mathrm{Cr}$ (III) hydroxides (Table 3.3). The initial rate of atmospheric oxygen reaction with mixed compounds of $\mathrm{Cr}$ (III) and $\mathrm{Ni}$ (II) or $\mathrm{Fe}(\mathrm{III})$ is of the same order as observed for pure $\mathrm{Cr}$ (III) hydroxides. The slightly more rapid reaction of the $\mathrm{Ni}$ (II) compound may be attributed to the possible catalytic effect of $\mathrm{Ni}(\mathrm{II})$ on the reaction.

Table 3.3. Initial Reaction Rate, $\mathrm{V}_{\mathrm{o}}$, for the Oxidation of $\mathrm{Cr}$ (III) Compounds by Atmospheric Oxygen in $3 \mathrm{M} \mathrm{NaOH}$

\begin{tabular}{|c|c|c|c|}
\hline Compound Number & Compound & $\mathrm{T},{ }^{\circ} \mathrm{C}$ & $\mathrm{V}_{0}$, moles/liter-hour \\
\hline II & $\mathrm{Cr}_{2} \mathrm{O}_{3} \cdot 4 \mathrm{H}_{2} \mathrm{O}$ & 70 & $3.0 \times 10^{-5}$ \\
\hline III & $\mathrm{Cr}_{2} \mathrm{O}_{3} \cdot 3.8 \mathrm{H}_{2} \mathrm{O}$ & 70 & $2.2 \times 10^{-5}$ \\
\hline IV & $\mathrm{Cr}_{2} \mathrm{O}_{3} \cdot 4 \mathrm{H}_{2} \mathrm{O}$ & 70 & $2.6 \times 10^{-5}$ \\
\hline V & $\mathrm{Cr}_{2} \mathrm{O}_{3} \cdot 2.9 \mathrm{H}_{2} \mathrm{O}$ & 70 & $1.5 \times 10^{-5}$ \\
\hline VI & $\mathrm{Cr}_{2} \mathrm{O}_{3} \cdot 2.4 \mathrm{H}_{2} \mathrm{O}$ & 70 & $1.2 \times 10^{-5}$ \\
\hline VII & $\mathrm{Cr}_{2} \mathrm{O}_{3} \cdot 2.35 \mathrm{H}_{2} \mathrm{O}$ & 70 & $1.4 \times 10^{-5}$ \\
\hline VII & $\mathrm{Cr}_{2} \mathrm{O}_{3} \cdot 2.35 \mathrm{H}_{2} \mathrm{O}$ & 80 & $2.6 \times 10^{-5}$ \\
\hline VIII & $\mathrm{Cr}_{2} \mathrm{O}_{3} \cdot 2.3 \mathrm{H}_{2} \mathrm{O}$ & 70 & $1.6 \times 10^{-5}$ \\
\hline VIII & $\mathrm{Cr}_{2} \mathrm{O}_{3} \cdot 2.3 \mathrm{H}_{2} \mathrm{O}$ & 60 & $1.0 \times 10^{-5}$ \\
\hline IX & $\mathrm{Cr}_{2} \mathrm{O}_{3} \cdot 2.7 \mathrm{H}_{2} \mathrm{O}$ & 70 & $5.0 \times 10^{-5}$ \\
\hline IX & $\mathrm{Cr}_{2} \mathrm{O}_{3} \cdot 2.7 \mathrm{H}_{2} \mathrm{O}$ & 60 & $3.4 \times 10^{-5}$ \\
\hline $\mathrm{X}$ & $\mathrm{NiCr}_{2} \mathrm{O}_{4} \cdot 5 \mathrm{H}_{2} \mathrm{O}$ & 80 & $4.9 \times 10^{-5}$ \\
\hline $\mathrm{XII}$ & $\mathrm{Fe}_{0.67} \mathrm{Cr}_{1.33} \mathrm{O}_{3} \cdot 2 \mathrm{H}_{2} \mathrm{O}$ & 80 & $2.0 \times 10^{-5}$ \\
\hline
\end{tabular}


The results of tests on longer-term oxidative dissolution of $\mathrm{Cr}$ (III) compounds by atmospheric oxygen showed that in all cases the reaction rates remained constant over the studied range of time (Figures 3.3 to 3.5). The rates are low at $80^{\circ} \mathrm{C}$ and $3 \mathrm{M} \mathrm{NaOH}$. Though the reaction can be accelerated at higher temperatures and alkali concentrations, achieving the complete oxidative dissolution of $\mathrm{Cr}(\mathrm{III})$ hydroxides (or leaching of chromium from other compounds) by atmospheric oxygen at atmospheric pressure may be impractical in process reactors but feasible for in-tank processing at longer residence times.

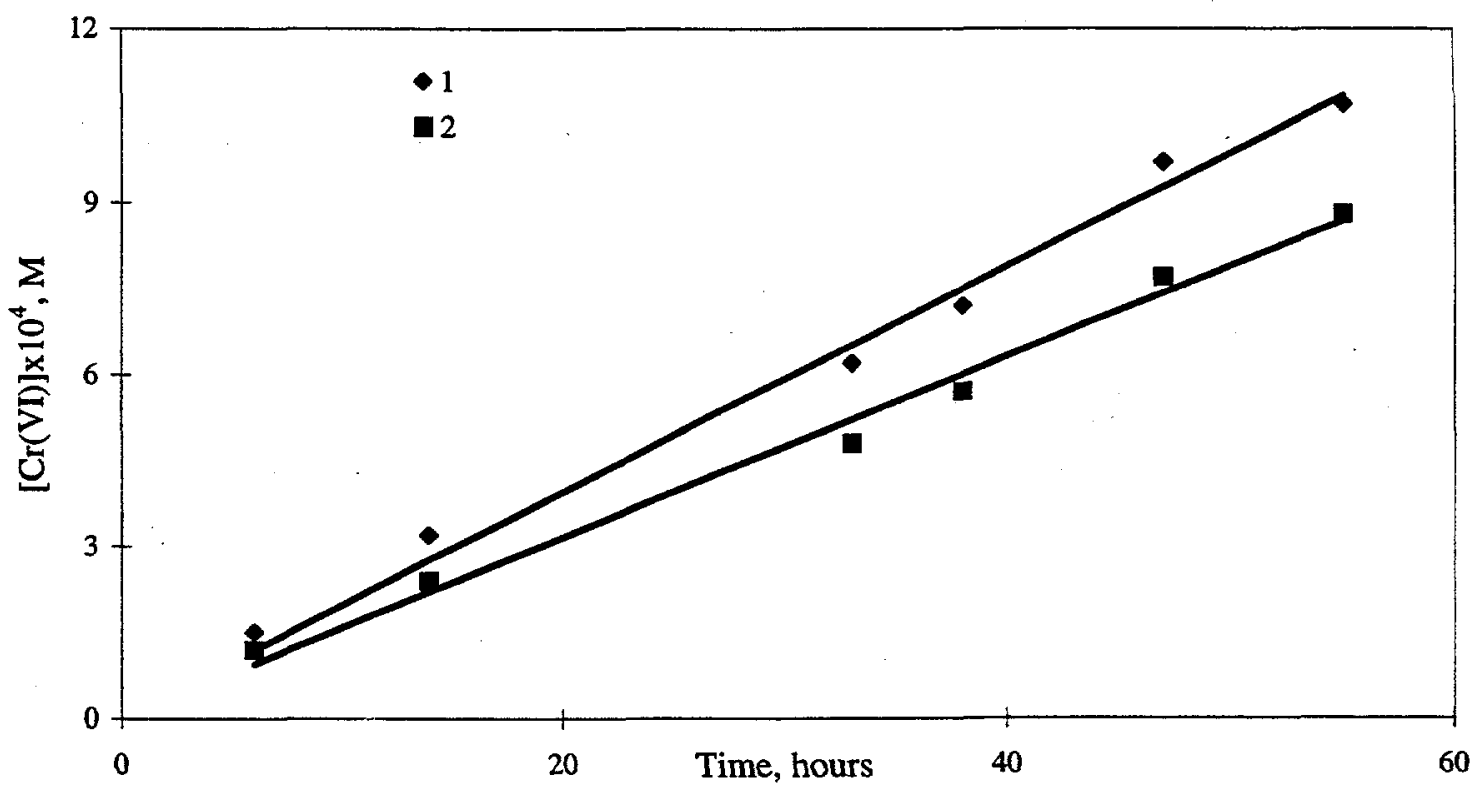

Figure 3.3. Long-Term Reaction of $\mathrm{Cr}(\mathrm{III})$ Compounds with Atmospheric Oxygen in $3 \mathrm{M} \mathrm{NaOH}$ at $80^{\circ} \mathrm{C}$ :

$1-\mathrm{Cr}_{2} \mathrm{O}_{3} \cdot 3.8 \mathrm{H}_{2} \mathrm{O}$ (compound III)

$2-\mathrm{Cr}_{2} \mathrm{O}_{3} \cdot 2 \cdot 4 \mathrm{H}_{2} \mathrm{O}$ (compound VI)

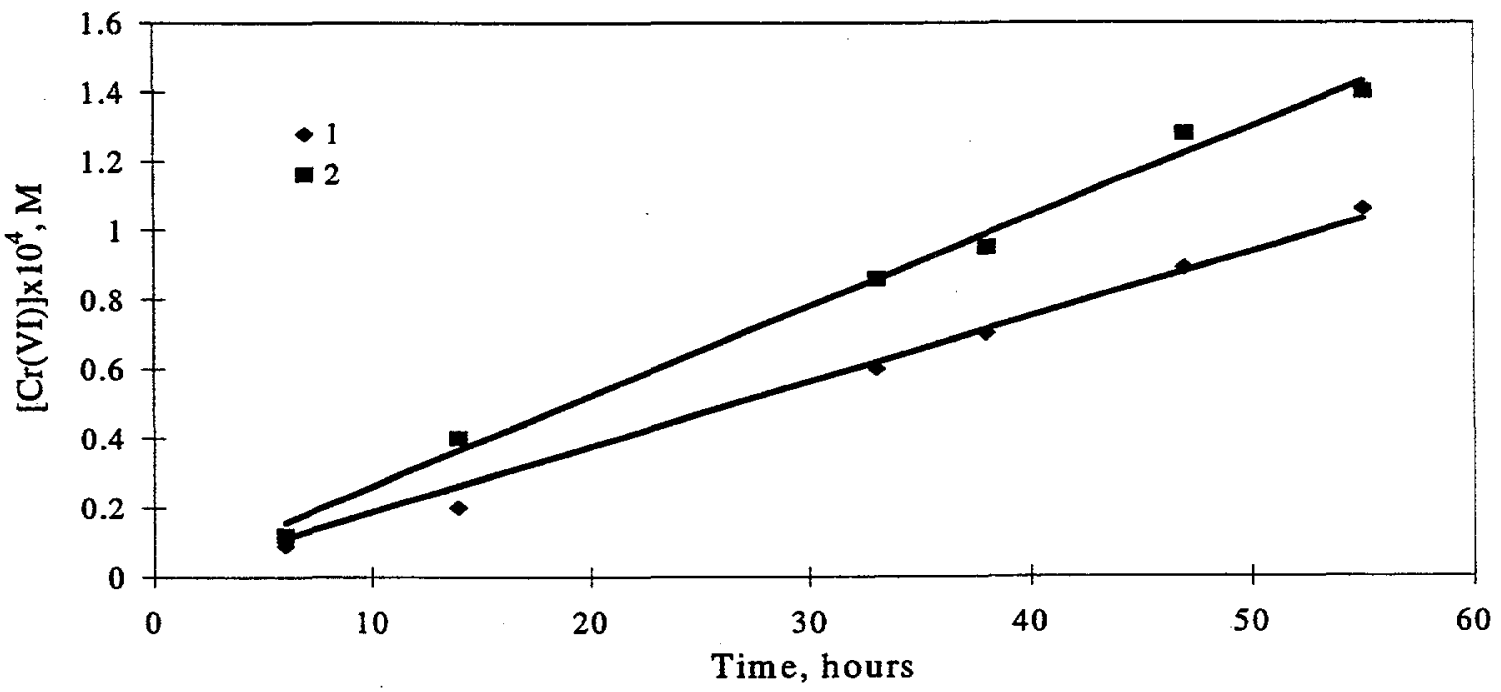

Figure 3.4. Long-Term Reaction of $\mathrm{Cr}$ (III) Compounds with Atmospheric

Oxygen in $3 \mathrm{M} \mathrm{NaOH}$ at $80^{\circ} \mathrm{C}$ :

$1-\mathrm{Cr}_{2} \mathrm{O}_{3} \cdot 2.9 \mathrm{H}_{2} \mathrm{O}$ (compound $\mathrm{V}$ )

$2-\mathrm{Cr}_{2} \mathrm{O}_{3} \cdot 2.3 \mathrm{H}_{2} \mathrm{O}$ (compound VIII) 


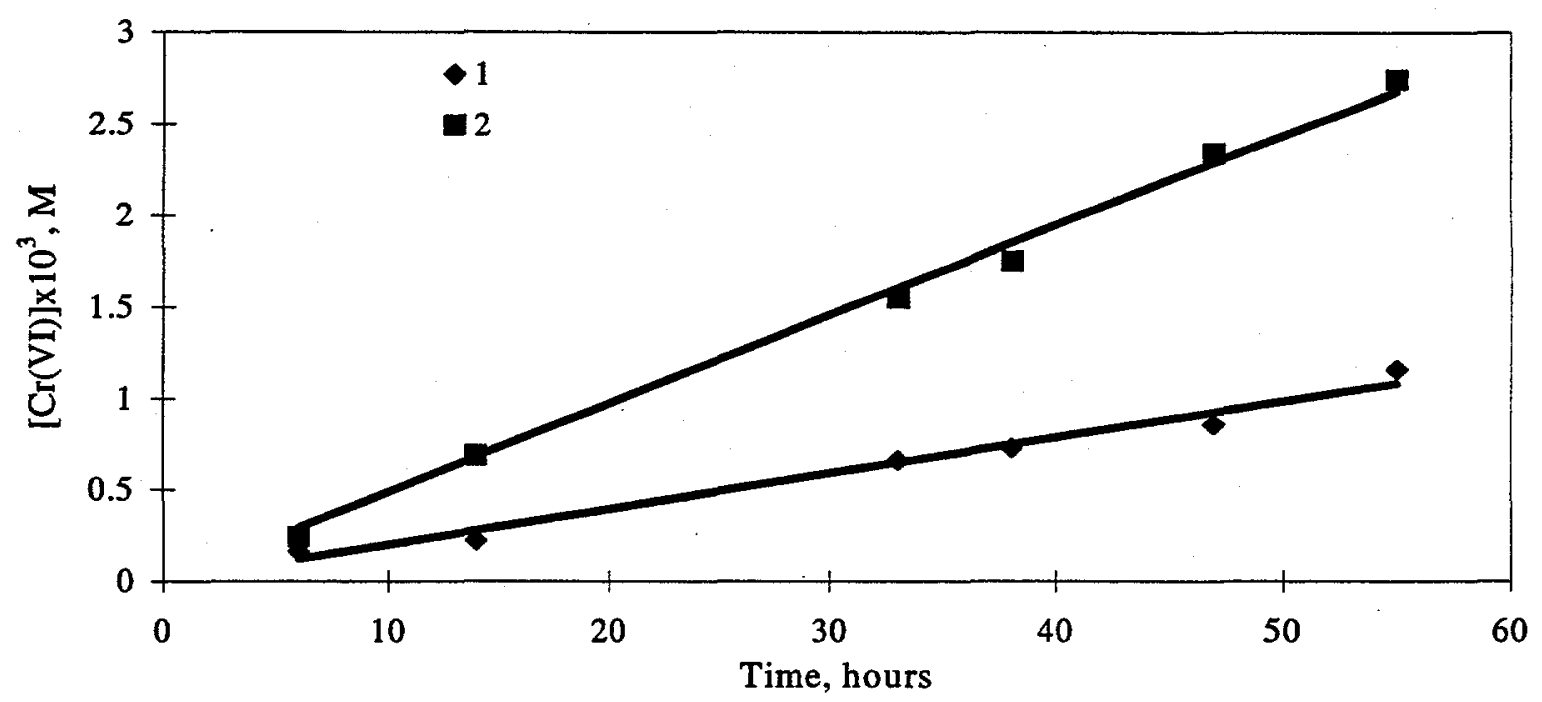

Figure 3.5. Long-Term Reaction of $\mathrm{Cr}$ (III) Compounds with Atmospheric Oxygen in $3 \mathrm{M} \mathrm{NaOH}$ at $80^{\circ} \mathrm{C}$ :

$1-\mathrm{Fe}_{0.67} \mathrm{Cr}_{1.33} \mathrm{O}_{3} \cdot 2 \mathrm{H}_{2} \mathrm{O}$ (compound $\mathrm{XII}$ )

$2-\mathrm{NiCr}_{2} \mathrm{O}_{4} \cdot 5 \mathrm{H}_{2} \mathrm{O}$ (compound $\mathrm{X}$ )

\subsection{Tests with Pure Oxygen}

The kinetics of the reaction of $\mathrm{Cr}$ (III) hydroxides with pure oxygen in alkaline suspensions is similar to those obtained with air. In both cases, the reaction rates are practically linear but have different slopes (greater rate for pure oxygen) under similar conditions (compare Figures 3.1 and 3.6). This means that the mechanisms of $\mathrm{Cr}$ (III) oxidation by air and pure oxygen are the same; that is, the process proceeds through the dissolution of $\mathrm{O}_{2}$ in alkaline solution.

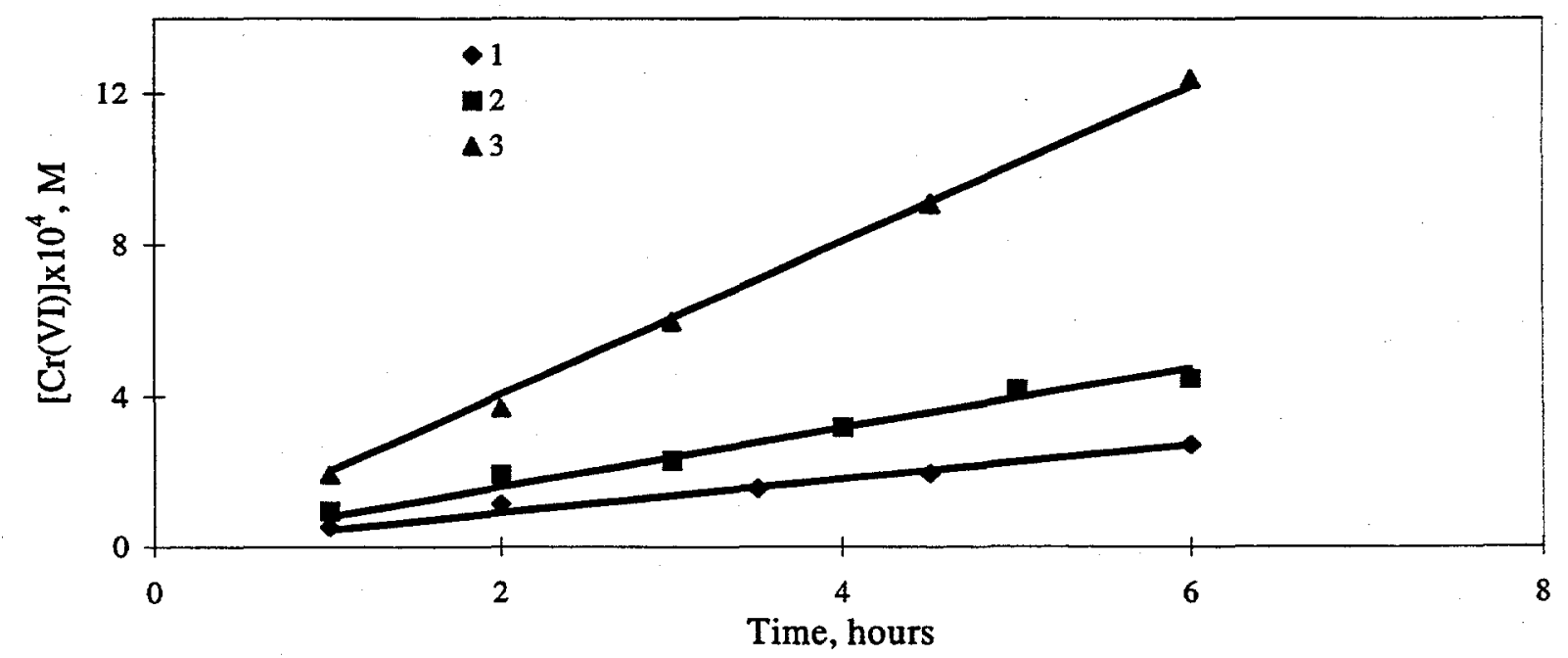

Figure 3.6. Kinetics of $0.02 \mathrm{M} \mathrm{Cr}$ (III) Hydroxide (compound II) Oxidation by Pure Oxygen at $70^{\circ} \mathrm{C}$ :

$[\mathrm{NaOH}], \mathrm{M}: 1-1 ; 2-2 ; 3-4$ 
Data on the influence of reaction conditions on the initial oxidation rate of $\mathrm{Cr}(\mathrm{III})$ hydroxides are presented in Table 3.4. A number of conclusions can be drawn from these data:

1. The reaction rate depends strongly on alkali concentration. The initial rate, $V_{0}$, is approximately proportional to $\mathrm{NaOH}$ concentration, although the actual correlation between rate and $\mathrm{NaOH}$ concentration seems to be somewhat more complex.

2. The $\mathrm{Cr}$ (III) oxidation rate increases in changing from air to pure oxygen and finally pure oxygen under elevated pressure. The hypothesis that $\mathrm{V}_{0}$ is proportional to the oxygen partial pressure $\left[\mathrm{P}\left(\mathrm{O}_{2}\right)\right]$ under otherwise similar conditions was tested and confirmed by the straightline dependence of $\mathrm{V}_{\mathrm{o}}$ on $\mathrm{P}\left(\mathrm{O}_{2}\right)$ in logarithmic coordinates with slope near 1 (Figure 3.7).

3. The rate of reaction with oxygen does not change by increasing $\mathrm{Cr}$ (III) hydroxide suspension concentrations above $0.02 \mathrm{M}$ in alkaline solution. But at $\mathrm{Cr}$ (III) concentration less than $0.02 \mathrm{M} \mathrm{V}_{\mathrm{o}}$ decreases, and at the lower $\mathrm{Cr}(\mathrm{III})$ hydroxide concentrations the rate of $\mathrm{Cr}$ (III) hydroxide dissolution is likely near its oxidation rate. Thus, a decrease in hydroxide suspension concentration below $0.02 \mathrm{M}$ decreases the steady-state $\mathrm{Cr}$ (III) solution concentration.

Table 3.4. Influence of Reaction Conditions on the Initial Rate of $\mathrm{Cr}$ (III) Hydroxide (compound II) Oxidation by Oxygen

\begin{tabular}{|c|c|c|c|c|}
\hline [NaOH], $\mathrm{M}$ & {$[\mathrm{Cr}(\mathrm{III})]_{0}, \mathrm{M}$} & $\mathrm{T},{ }^{\circ} \mathrm{C}$ & $\mathrm{P}$, atm. & $\mathrm{V}_{0}$, moles/liter-hour \\
\hline 0.2 & \multirow[t]{6}{*}{0.02} & \multirow[t]{6}{*}{70.0} & \multirow[t]{6}{*}{1} & $0.08 \times 10^{-4}$ \\
\hline 1.0 & & & & $0.40 \times 10^{-4}$ \\
\hline 2.0 & & & & $0.71 \times 10^{-4}$ \\
\hline 3.0 & & & & $1.32 \times 10^{-4}$ \\
\hline 4.0 & & & & $1.95 \times 10^{-4}$ \\
\hline 5.0 & & & & $2.34 \times 10^{-4}$ \\
\hline \multirow[t]{5}{*}{2.0} & \multirow[t]{5}{*}{0.02} & 40.0 & \multirow[t]{5}{*}{1} & $0.25 \times 10^{-4}$ \\
\hline & & 60.0 & & $0.42 \times 10^{-4}$ \\
\hline & & 70.0 & & $0.67 \times 10^{-4}$ \\
\hline & & 80.0 & & $0.74 \times 10^{-4}$ \\
\hline & & 90.0 & & $0.95 \times 10^{-4}$ \\
\hline \multirow[t]{4}{*}{4.0} & \multirow[t]{4}{*}{0.02} & 45.0 & \multirow[t]{4}{*}{1} & $0.55 \times 10^{-4}$ \\
\hline & & 60.0 & & $1.12 \times 10^{-4}$ \\
\hline & & 70.0 & & $1.80 \times 10^{-4}$ \\
\hline & & 80.0 & & $2.27 \times 10^{-4}$ \\
\hline \multirow[t]{3}{*}{4.0} & 0.005 & \multirow[t]{3}{*}{70.0} & \multirow[t]{3}{*}{1} & $0.58 \times 10^{-4}$ \\
\hline & 0.01 & & & $1.15 \times 10^{-4}$ \\
\hline & 0.05 & & & $1.93 \times 10^{-4}$ \\
\hline 1.0 & \multirow[t]{5}{*}{0.02} & \multirow[t]{5}{*}{70.0} & 2 & $0.75 \times 10^{-4}$ \\
\hline 2.0 & & & 2 & $1.45 \times 10^{-4}$ \\
\hline 3.0 & & & 2 & $2.6 \times 10^{-4}$ \\
\hline 3.0 & & & 3 & $3.6 \times 10^{-4}$ \\
\hline 4.0 & & & 2 & $3.5 \times 10^{-4}$ \\
\hline \multirow[t]{4}{*}{2.0} & \multirow[t]{4}{*}{0.02} & 40.0 & \multirow[t]{4}{*}{2} & $0.50 \times 10^{-4}$ \\
\hline & & 60.0 & & $0.81 \times 10^{-4}$ \\
\hline & & 70.0 & & $1.25 \times 10^{-4}$ \\
\hline & & 80.0 & & $1.83 \times 10^{-4}$ \\
\hline
\end{tabular}




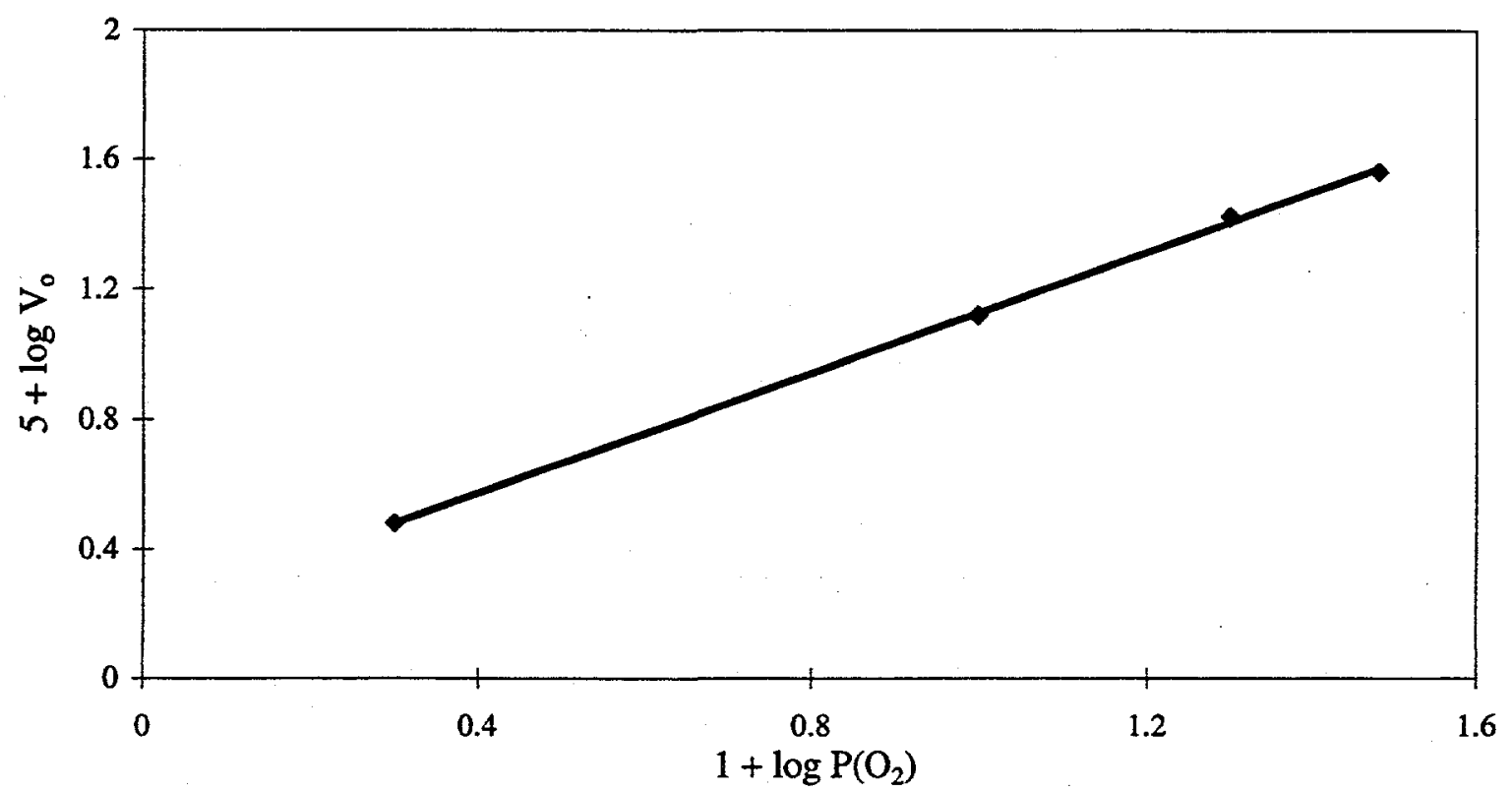

Figure 3.7. Influence of $\mathrm{O}_{2}$ Pressure on the Oxidation Rate of $0.02 \mathrm{M} \mathrm{Cr}$ (III) Hydroxide (compound III) in $3 \mathrm{M} \mathrm{NaOH}$ at $70^{\circ} \mathrm{C}$

As found in tests of oxidation by air, the initial rate of $\mathrm{Cr}(\mathrm{III})$ hydroxide oxidation in pure oxygen is not strongly dependent on temperature. The dependence of $\mathrm{V}_{0}$ on temperature is linear in Arrhenius coordinates (Figure 3.8), with slopes indicating a formal activation energy, $E_{a}$, in the range 26 to 36 $\mathrm{kJ} / \mathrm{mole}$. The decreasing oxygen solubility in alkaline solutions with increasing temperature undoubtedly contributes to the unusually low $\mathrm{E}_{\mathrm{a}}$.

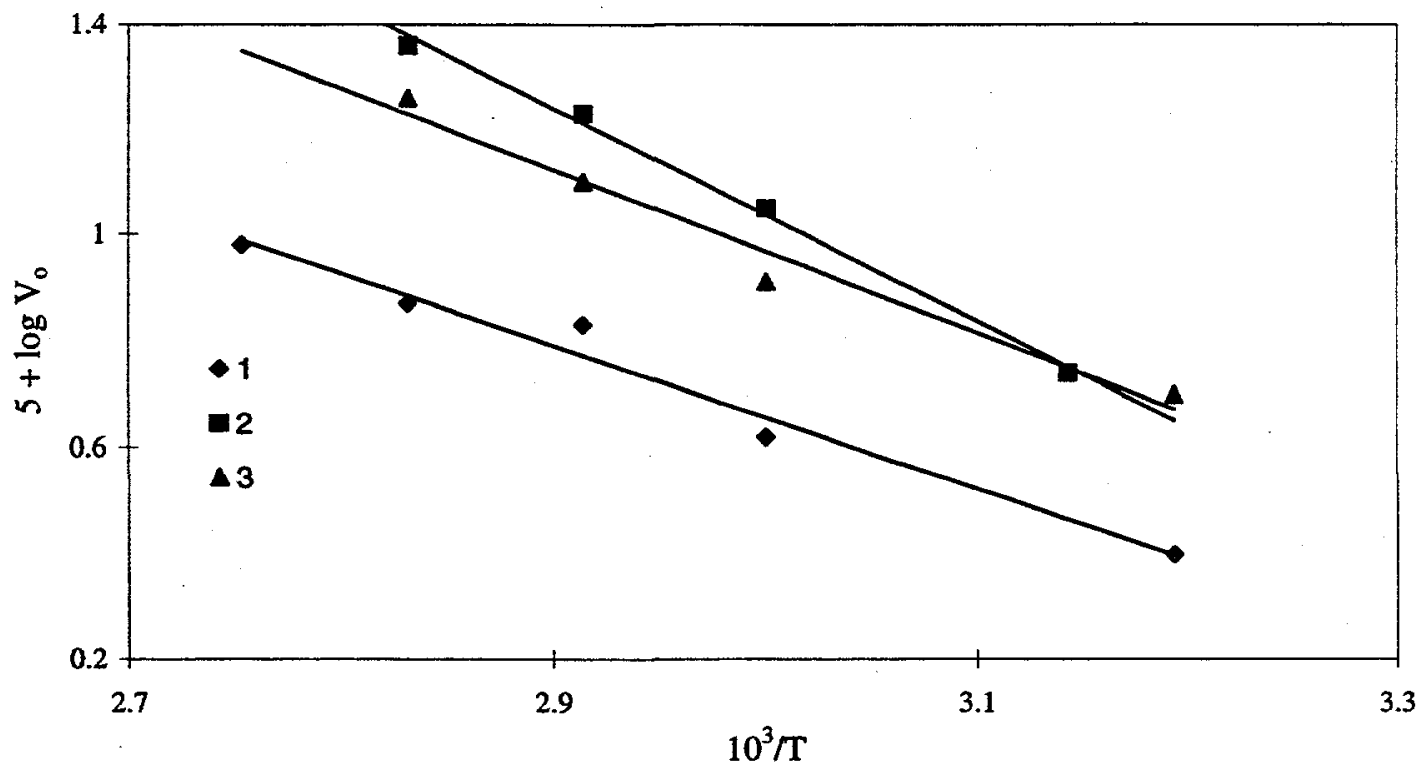

Figure 3.8. Effect of Temperature on the Rate of $\mathrm{Cr}(\mathrm{III})$ Hydroxide

(compound II) Oxidation by Pure Oxygen; $[\mathrm{Cr}(\mathrm{III})]_{0}=0.02 \mathrm{M}$ :

1 - $2 \mathrm{M} \mathrm{NaOH}, 1$ atm $\mathrm{O}_{2} ; 2$ - $4 \mathrm{M} \mathrm{NaOH}, 1$ atm O ;

3 - $2 \mathrm{M} \mathrm{NaOH}, 2$ atm $\mathrm{O}_{2}$ 
Data from Tables 3.5 and 3.6 illustrate the influence of the $\mathrm{Cr}(\mathrm{III})$ compound on the oxidative leaching rate. The tendency of $V_{0}$ to decrease with increasing hydrothermal coagulation temperature is obvious but is not monotonic. Thus one of the $\mathrm{Cr}$ (III) hydroxide compounds (IX), hydrothermally treated at $250^{\circ} \mathrm{C}$, showed an anomalously high oxidation rate by oxygen. A relatively high oxidative leaching rate of chromium also was observed in the case of the two $\mathrm{NiCr}_{2} \mathrm{O}_{4} \cdot \mathrm{nH}_{2} \mathrm{O}$ compounds (X and XI). It was postulated that $\mathrm{Ni}$ (II) is a catalyst for $\mathrm{Cr}(\mathrm{III})$ oxidation by $\mathrm{O}_{2}$ in alkaline media. This supposition was verified by special tests in which the initial rate of $\mathrm{O}_{2}$ reaction with $\mathrm{Cr}$ (III) hydroxide compounds $\mathrm{IX}$ and VI in $3 \mathrm{M} \mathrm{NaOH}$ at $70^{\circ} \mathrm{C}$ increased about two-fold after adding $2 \times 10^{-3} \mathrm{M} \mathrm{Ni}$ (II).

The curves in Figures 3.9 to 3.11 describe the effects of more prolonged reaction of pure oxygen with different $\mathrm{Cr}$ (III) compounds in $3 \mathrm{M} \mathrm{NaOH}$ at $80^{\circ} \mathrm{C}$. As expected, $\mathrm{Cr}(\mathrm{VI})$ accumulated in solution at approximately constant rates over the studied time intervals. Unfortunately, however, the dissolution process was slow under the test conditions, especially for the compounds aged at elevated temperatures.

Table 3.5. Comparison of the Oxidation Rates of Different $\mathrm{Cr}(\mathrm{III})$ Hydroxides by Oxygen

\begin{tabular}{|c|c|c|c|c|c|c|c|}
\hline$[\mathrm{NaOH}], \mathrm{M}$ & \multirow{2}{*}{$\mathrm{T},{ }^{\circ} \mathrm{C}$} & \multicolumn{5}{|c|}{$\mathrm{V}_{\mathrm{o}}$, moles/liter-hour, for various $\mathrm{Cr}$ (III) hydroxide compounds } \\
\cline { 3 - 7 } & & $\mathrm{II}$ & $\mathrm{II}$ & $\mathrm{V}$ & $\mathrm{VI}$ & $\mathrm{VII}$ & $\mathrm{IX}$ \\
\hline 2 & 70 & $0.71 \times 10^{-4}$ & $0.55 \times 10^{-4}$ & $0.30 \times 10^{-4}$ & $0.45 \times 10^{-4}$ & $0.45 \times 10^{-4}$ & $0.90 \times 10^{-4}$ \\
\hline 3 & 70 & $1.32 \times 10^{-4}$ & $1.22 \times 10^{-4}$ & $0.43 \times 10^{-4}$ & $0.50 \times 10^{-4}$ & $0.61 \times 10^{-4}$ & $1.20 \times 10^{-4}$ \\
\hline 4 & 70 & $1.95 \times 10^{-4}$ & - & $0.80 \times 10^{-4}$ & $0.80 \times 10^{-4}$ & $1.10 \times 10^{-4}$ & $2.10 \times 10^{-4}$ \\
\hline 3 & 60 & $1.10 \times 10^{-4}$ & - & $0.20 \times 10^{-4}$ & $0.40 \times 10^{-4}$ & - & $1.10 \times 10^{-4}$ \\
\hline 3 & 80 & $1.85 \times 10^{-4}$ & $1.70 \times 10^{-4}$ & $0.70 \times 10^{-4}$ & $0.70 \times 10^{-4}$ & $0.9 \times 10^{-4}$ & $1.70 \times 10^{-4}$ \\
\hline
\end{tabular}

Table 3.6. Comparison of the Oxidation Rates of Different $\mathrm{Cr}$ (III) Compounds by Oxygen

\begin{tabular}{|c|c|c|c|c|c|c|}
\hline$[\mathrm{NaOH}], \mathrm{M}$ & \multirow{2}{*}{${ }^{\circ}{ }^{\circ} \mathrm{C}$} & \multicolumn{5}{|c|}{$\mathrm{V}_{\mathrm{o}}$, moles/liter-hour, for various $\mathrm{Cr}$ (III) compounds } \\
\cline { 3 - 7 } & & $\mathrm{X}$ & $\mathrm{XI}$ & $\mathrm{XI}$ & $\mathrm{XII}$ & $\mathrm{XIV}$ \\
\hline 3.0 & 60 & $1.4 \times 10^{-4}$ & $1.0 \times 10^{-4}$ & $0.3 \times 10^{-4}$ & $0.2 \times 10^{-4}$ & $0.3 \times 10^{-4}$ \\
\hline 3.0 & 70 & $1.8 \times 10^{-4}$ & $1.6 \times 10^{-4}$ & $0.6 \times 10^{-4}$ & $0.6 \times 10^{-4}$ & $0.5 \times 10^{-4}$ \\
\hline 3.0 & 80 & $2.4 \times 10^{-4}$ & $1.9 \times 10^{-4}$ & $1.0 \times 10^{-4}$ & $0.9 \times 10^{-4}$ & $0.8 \times 10^{-4}$ \\
\hline
\end{tabular}

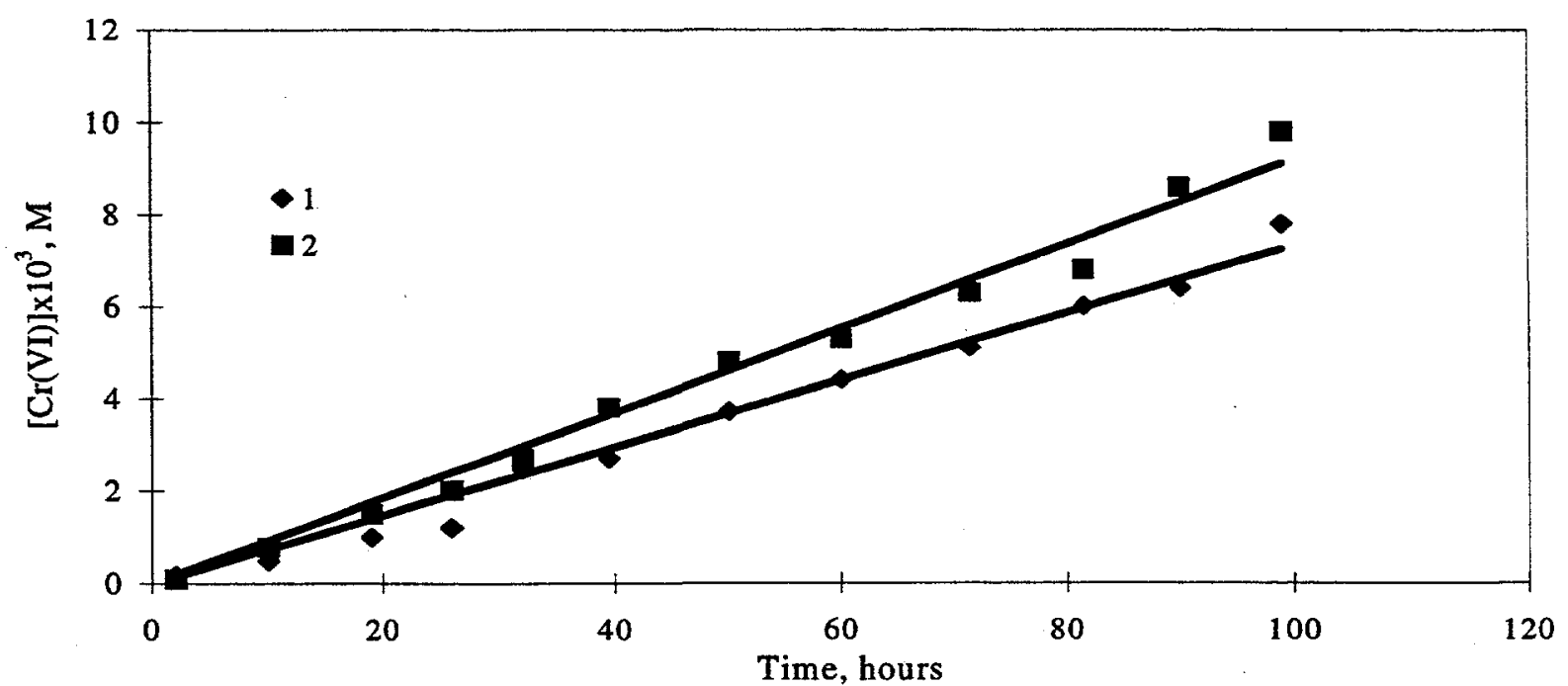

Figure 3.9. Long-Term Reaction of $\mathrm{Cr}$ (III) Hydroxides with 1 atm Pure Oxygen in $3 \mathrm{M} \mathrm{NaOH}$ at $80^{\circ} \mathrm{C}$, $\mathrm{Cr}(\mathrm{III})]_{0}=0.02 \mathrm{M}: 1-\mathrm{Cr}_{2} \mathrm{O}_{3} \cdot 3.8 \mathrm{H}_{2} \mathrm{O}$ (compound III); $2-\mathrm{Cr}_{2} \mathrm{O}_{3} \cdot 2.7 \mathrm{H}_{2} \mathrm{O}$ (compound $\mathrm{IX}$ ) 


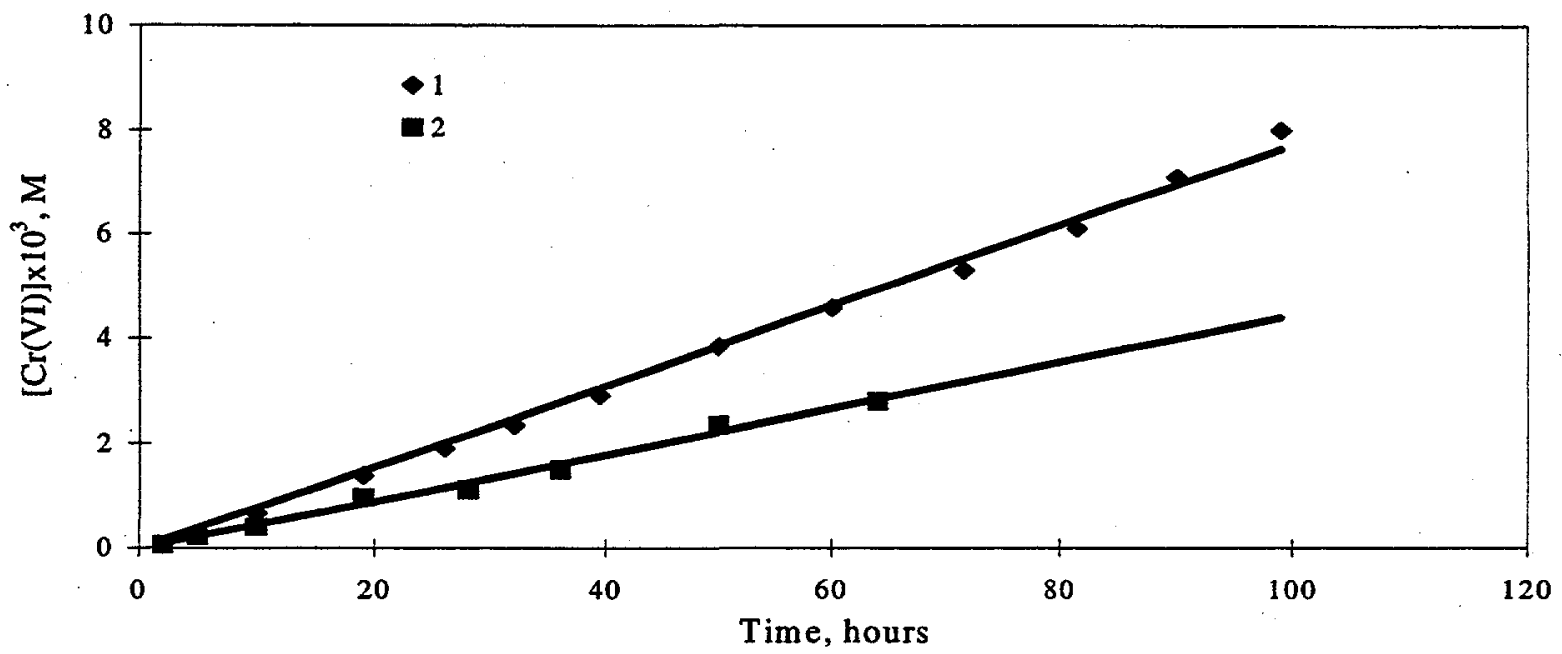

Figure 3.10. Long-Term Reaction of $\mathrm{Cr}$ (III) Compounds with 1 atm Pure Oxygen in $3 \mathrm{M} \mathrm{NaOH}$ at $80^{\circ} \mathrm{C} ;[\mathrm{Cr}(\mathrm{III})]_{0}=0.02 \mathrm{M}$ :

$1-\mathrm{Cr}_{2} \mathrm{O}_{3} \cdot 2.9 \mathrm{H}_{2} \mathrm{O}$ (compound $\mathrm{V}$ ); $2-\mathrm{Cr}_{2} \mathrm{O}_{3} \cdot 2.4 \mathrm{H}_{2} \mathrm{O}$ (compound $\mathrm{VI}$ )

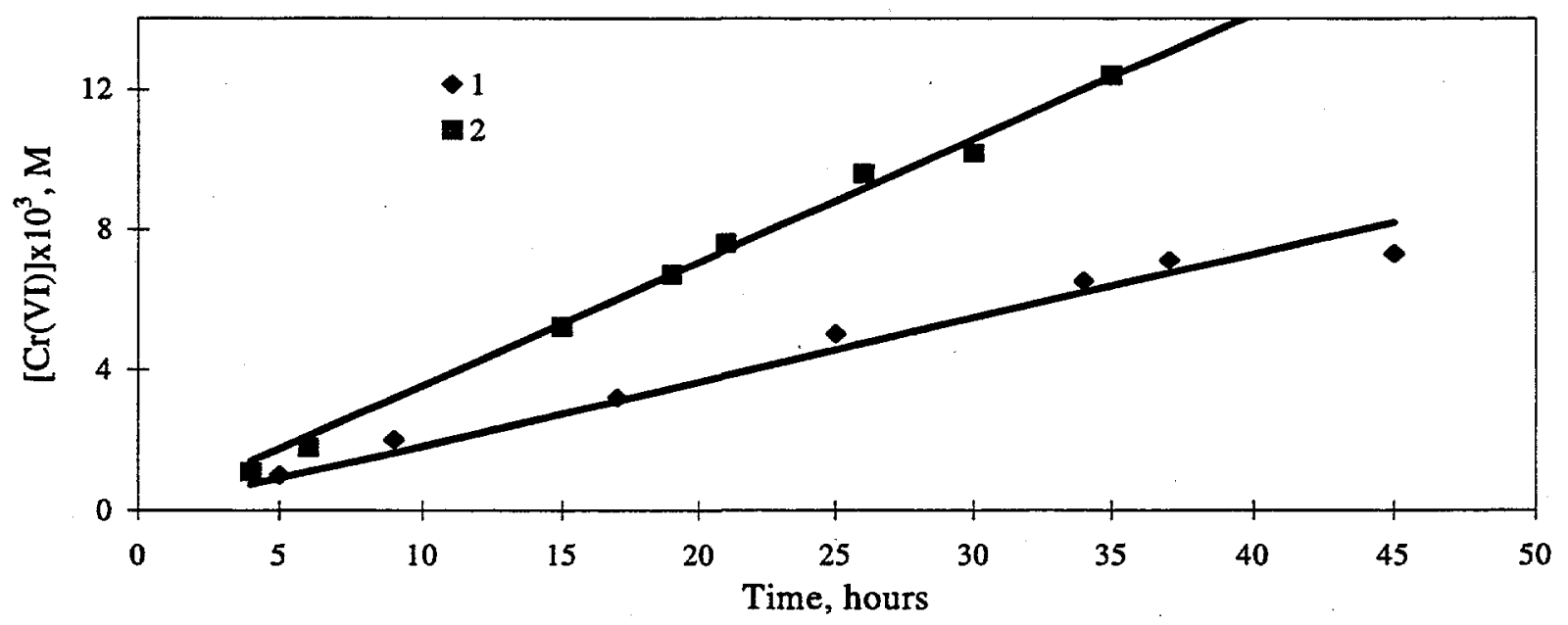

Figure 3.11. Long-Term Reaction of $\mathrm{Cr}$ (III) Hydroxides with Pure Oxygen with $2 \mathrm{~atm}$ Pressure in $3 \mathrm{M} \mathrm{NaOH}$ at $80^{\circ} \mathrm{C}$; $[\mathrm{Cr}(\mathrm{III})]_{0}=0.02 \mathrm{M}$ : $1-\mathrm{Cr}_{2} \mathrm{O}_{3} \cdot 2.9 \mathrm{H}_{2} \mathrm{O}$ (compound $\mathrm{V}$ ) $2-\mathrm{Cr}_{2} \mathrm{O}_{3} \cdot 3.8 \mathrm{H}_{2} \mathrm{O}$ (compound III) 


\subsection{Oxidative Alkaline Dissolution of Chromium(III) Compounds by Hydrogen Peroxide}

\subsection{Effect of Conditions on the Rate of $\mathrm{Cr}(\mathrm{III})$ Hydroxide Oxidation by $\mathrm{H}_{2} \mathrm{O}_{2}$}

Preliminary tests showed that the oxidation of $\mathrm{Cr}(\mathrm{III})$ hydroxide compounds in 0.2 to $3 \mathrm{M} \mathrm{NaOH}$ proceeds at rates convenient for measurement at 40 to $80^{\circ} \mathrm{C}$. These conditions were chosen for most testing. Typical kinetic curves of the reaction are seen in Figure 4.1. These curves cannot be described by a simple kinetic rate law because the $\mathrm{Cr}(\mathrm{III})$ oxidation is accompanied by pronounced catalytic decomposition of $\mathrm{H}_{2} \mathrm{O}_{2}$. Therefore, the kinetic curves were used only to determine the initial reaction rate and, in some cases, the final yield of $\mathrm{Cr}(\mathrm{VI})$.

It is evident that the initial rate, $\mathrm{V}_{0}$, of $\mathrm{Cr}(\mathrm{III})$ oxidation by $\mathrm{H}_{2} \mathrm{O}_{2}$ follows the expressions:

$$
\text { or } \begin{aligned}
& \mathrm{V}_{\mathrm{o}}=\lim (\mathrm{d}[\mathrm{Cr}(\mathrm{VI})] / \mathrm{d} \tau) \text { as } \tau \rightarrow 0 \\
& \mathrm{~V}_{\mathrm{o}} \cong \mathrm{k}\left([\mathrm{Cr}(\mathrm{III})]_{0}\right)^{\mathrm{m}}\left(\left[\mathrm{H}_{2} \mathrm{O}_{2}\right]_{0}\right)^{\mathrm{n}}
\end{aligned}
$$

where $m$ and $n$ are the reaction orders in terms of $\mathrm{Cr}(\mathrm{III})$ and $\mathrm{H}_{2} \mathrm{O}_{2}$ concentrations, $k$ is the reaction rate constant, and $\tau$ is reaction time. The equation assumes that the rate of the heterogeneous reaction is controlled by solid-phase surface area and thus is proportional to uniform suspension concentration.

To estimate $m$ and $n$, the dependence of $\mathrm{V}_{0}$ on $[\mathrm{Cr}(\mathrm{III})]_{0}$ and $\left[\mathrm{H}_{2} \mathrm{O}_{2}\right]_{0}$ were determined for the $\mathrm{Cr}$ (III) hydroxide compound II. As seen from data in Table 4.1, $\mathrm{V}_{\mathrm{o}}$ increases monotonically with increasing $\mathrm{Cr}$ (III) concentration under otherwise similar conditions. These data (Figure 4.2) show that $\log \left(V_{0}\right)$ increases linearly at slope $\sim 1$ with increase in $\log \left([\mathrm{Cr}(\mathrm{III})]_{0}\right)$. Therefore, $\mathrm{m}$ is equal to 1 .

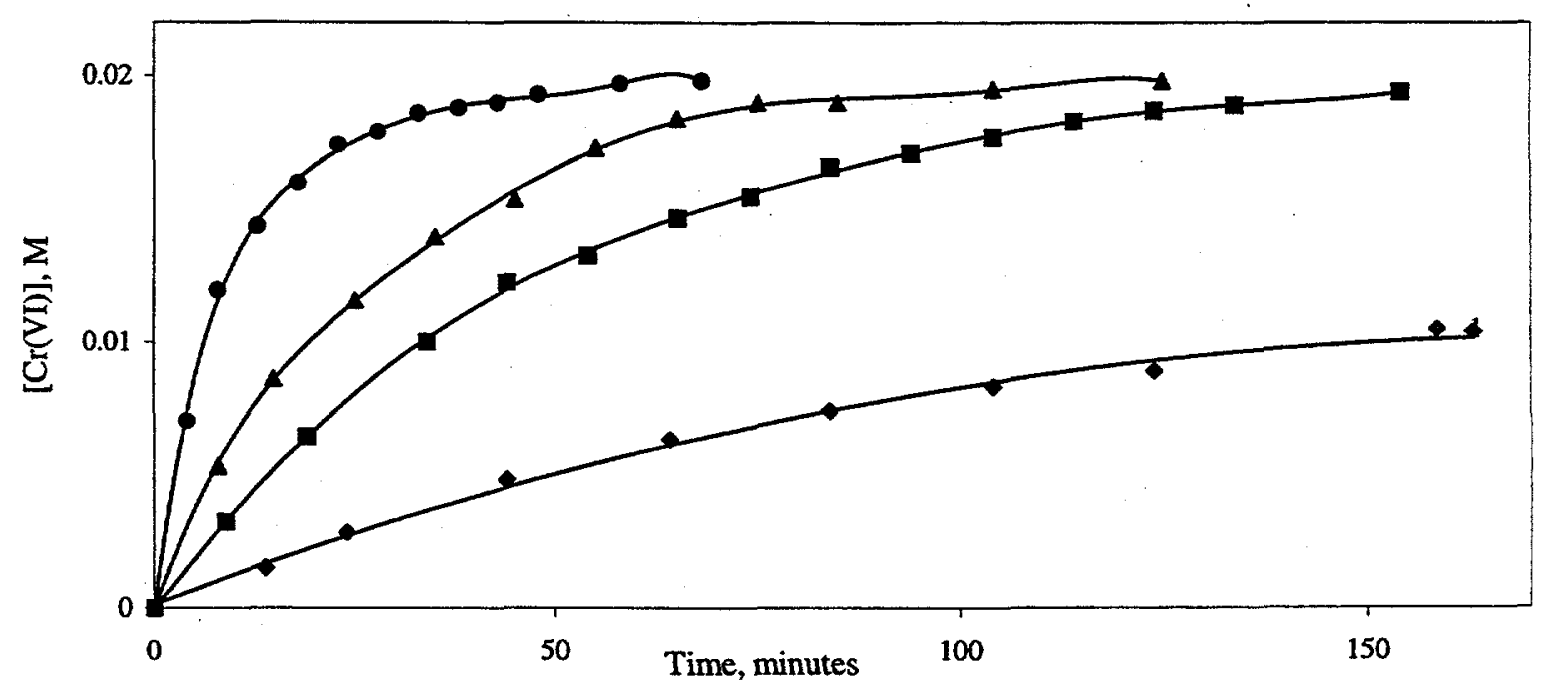

Figure 4.1. Kinetics of Oxidation of $0.02 \mathrm{M} \mathrm{Cr}$ (III) Hydroxide (compound II) by $0.1 \mathrm{M} \mathrm{H}_{2} \mathrm{O}_{2}$ :

1 - $3 \mathrm{M} \mathrm{NaOH}, 40^{\circ} \mathrm{C}$;

3 - $3 \mathrm{M} \mathrm{NaOH}, 60^{\circ} \mathrm{C}$;
$2-0.5 \mathrm{M} \mathrm{NaOH}, 50^{\circ} \mathrm{C}$

$4-0.5 \mathrm{M} \mathrm{NaOH}, 70^{\circ} \mathrm{C}$ 
Table 4.1. Initial Rate of $\mathrm{Cr}_{2} \mathrm{O}_{3} \cdot 4 \mathrm{H}_{2} \mathrm{O}$ (compound II) Oxidation by $\mathrm{H}_{2} \mathrm{O}_{2}$ in $3 \mathrm{M} \mathrm{NaOH}$

\begin{tabular}{|c|c|c|c|}
\hline$[\mathrm{Cr}(\mathrm{III})]_{0}, \mathrm{M}$ & {$\left[\mathrm{H}_{2} \mathrm{O}_{2}\right]_{0}, \mathrm{M}$} & $\mathrm{T},{ }^{\circ} \mathrm{C}$ & $\mathrm{V}_{\mathrm{o}}$, moles/liter-minute \\
\hline 0.010 & \multirow[t]{6}{*}{0.04} & \multirow[t]{6}{*}{60.0} & $1.4 \times 10^{-4}$ \\
\hline 0.016 & & & $1.9 \times 10^{-4}$ \\
\hline 0.018 & & & $2.6 \times 10^{-4}$ \\
\hline 0.020 & & & $3.0 \times 10^{-4}$ \\
\hline 0.040 & & & $4.2 \times 10^{-4}$ \\
\hline 0.068 & & & $8.7 \times 10^{-4}$ \\
\hline \multirow[t]{5}{*}{0.020} & 0.02 & \multirow[t]{5}{*}{40.0} & $0.37 \times 10^{-4}$ \\
\hline & 0.025 & & $0.42 \times 10^{-4}$ \\
\hline & 0.05 & & $0.72 \times 10^{-4}$ \\
\hline & 0.125 & & $1.26 \times 10^{-4}$ \\
\hline & 0.25 & & $1.60 \times 10^{-4}$ \\
\hline \multirow[t]{7}{*}{0.020} & 0.02 & \multirow[t]{7}{*}{60.0} & $1.78 \times 10^{-4}$ \\
\hline & 0.02 & & $2.00 \times 10^{-4}$ \\
\hline & 0.04 & & $3.02 \times 10^{-4}$ \\
\hline & 0.10 & & $5.25 \times 10^{-4}$ \\
\hline & 0.10 & & $6.10 \times 10^{-4}$ \\
\hline & 0.20 & & $8.60 \times 10^{-4}$ \\
\hline & 0.20 & & $8.70 \times 10^{-4}$ \\
\hline
\end{tabular}

The dependence of $\mathrm{V}_{\mathrm{o}}$ on $\mathrm{H}_{2} \mathrm{O}_{2}$ concentration in logarithmic coordinates also is linear (Figure 4.3), but the slope (the exponent $n$ ) is $\sim 0.62$. A fractional reaction order with respect to $\mathrm{H}_{2} \mathrm{O}_{2}$ concentration is difficult to explain. It may be that the actual reaction order is 1 but becomes less than 1 because $\mathrm{H}_{2} \mathrm{O}_{2}$ catalytic decomposition to form $\mathrm{O}_{2}$ gas bubbles on the $\mathrm{Cr}$ (III) hydroxide particle surface decreases the surface exposed to the $\mathrm{H}_{2} \mathrm{O}_{2}$ solution for dissolution. The decreased surface area then would be reflected in the accompanying decrease in $\mathrm{V}_{\mathrm{o}}$.

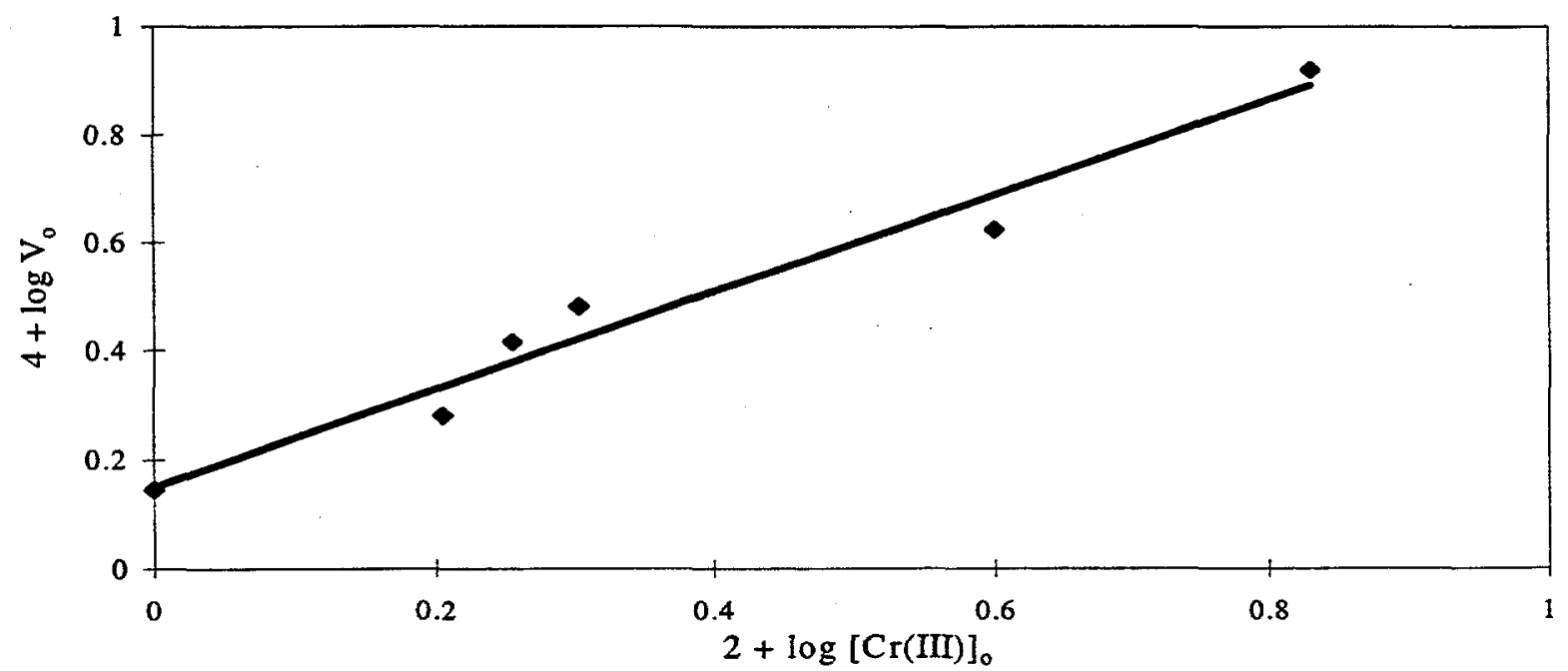

Figure 4.2. Effect of $[\mathrm{Cr}(\mathrm{III})]_{0}$ on the Rate of $\mathrm{Cr}_{2} \mathrm{O}_{3} \cdot 4 \mathrm{H}_{2} \mathrm{O}$ (compound II) Oxidation by $0.04 \mathrm{M} \mathrm{H}_{2} \mathrm{O}_{2}$ at $60^{\circ} \mathrm{C}$ in $3 \mathrm{M} \mathrm{NaOH}$ 


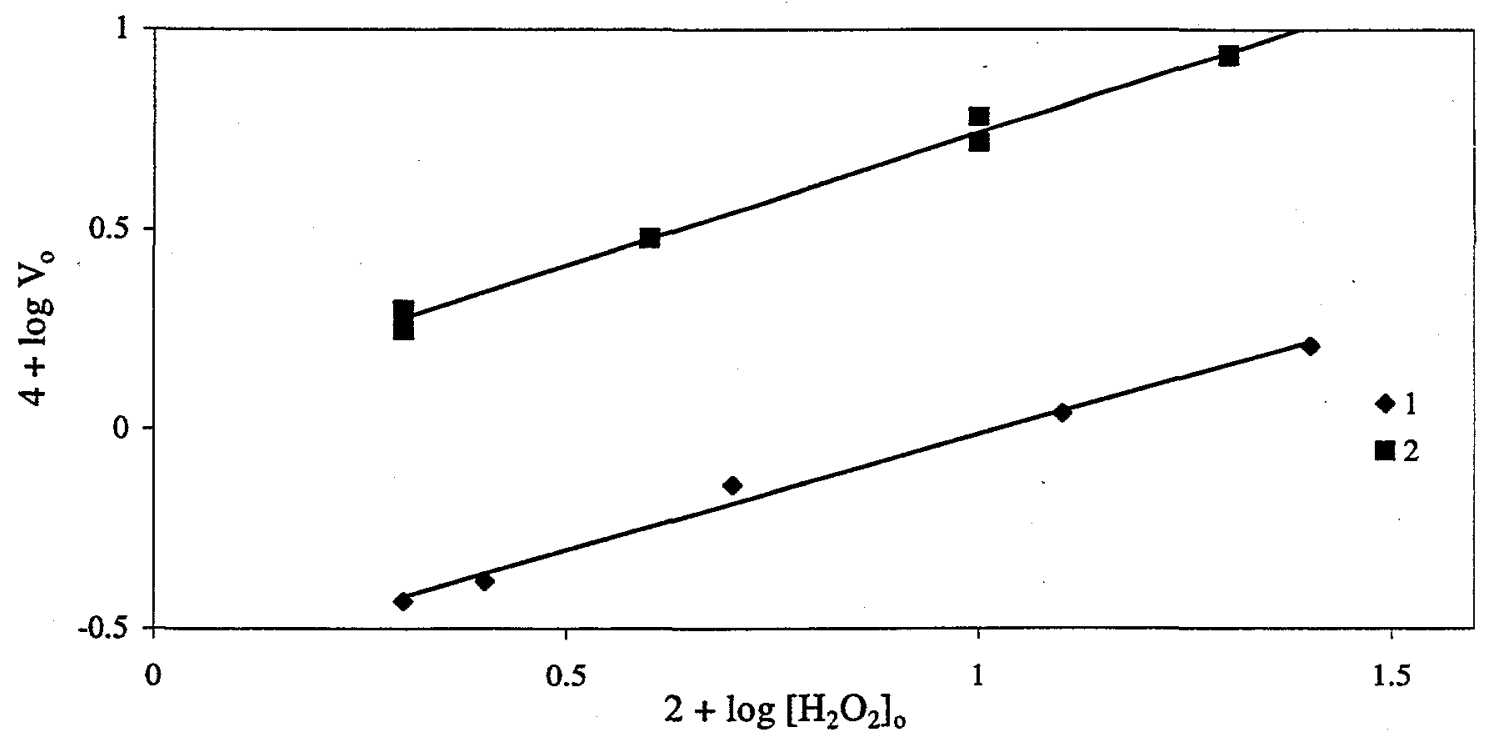

Figure 4.3. Effect of $\mathrm{H}_{2} \mathrm{O}_{2}$ Concentration on the Initial Rate of Oxidation of $0.02 \mathrm{M} \mathrm{Cr}$ (III) Hydroxide (compound II) in $3 \mathrm{M} \mathrm{NaOH}$ :

$$
1-40^{\circ} \mathrm{C} ; \quad 2-60^{\circ} \mathrm{C}
$$

The data presented in Table 4.2 show that the rate of $\mathrm{Cr}$ (III) oxidation at constant initial $\mathrm{H}_{2} \mathrm{O}_{2}$ concentration decreases steeply with increasing $\mathrm{NaOH}$ concentration and strongly increases with temperature. The dependence of $\mathrm{V}_{0}$ on temperature is linear in Arrhenius coordinates (Figure 4.4), with slope corresponding to an activation energy, $E_{\mathrm{a}}$, of $82 \mathrm{~kJ} / \mathrm{mole}$ at $0.5 \mathrm{M} \mathrm{NaOH}$.

Table 4.2. Influence of Temperature and $\mathrm{NaOH}$ Concentration on Initial Rate Rate of $0.02 \mathrm{M} \mathrm{Cr}_{2} \mathrm{O}_{3} \cdot 4 \mathrm{H}_{2} \mathrm{O}$ (compound $\mathrm{I}$ ) Oxidation by $\mathrm{H}_{2} \mathrm{O}_{2}$

\begin{tabular}{|c|c|c|c|}
\hline$\left[\mathrm{H}_{2} \mathrm{O}_{2}\right]_{0}, \mathrm{M}$ & $\mathrm{T},{ }^{\circ} \mathrm{C}$ & {$[\mathrm{NaOH}]_{0}, \mathrm{M}$} & $\mathrm{V}_{0}$, moles/liter-minute \\
\hline \multirow[t]{8}{*}{0.04} & 30.0 & \multirow[t]{8}{*}{0.5} & $0.31 \times 10^{-4}$ \\
\hline & 40.0 & & $0.68 \times 10^{-4}$ \\
\hline & 50.0 & & $1.87 \times 10^{-4}$ \\
\hline & 60.0 & & $5.40 \times 10^{-4}$ \\
\hline & 70.0 & & $9.46 \times 10^{-4}$ \\
\hline & 70.0 & & $8.80 \times 10^{-4}$ \\
\hline & 80.0 & & $25.0 \times 10^{-4}$ \\
\hline & 90.0 & & $62.0 \times 10^{-4}$ \\
\hline \multirow[t]{7}{*}{0.02} & \multirow[t]{7}{*}{60.0} & 0.2 & $6.3 \times 10^{-4}$ \\
\hline & & 0.2 & $8.3 \times 10^{-4}$ \\
\hline & & 0.5 & $3.7 \times 10^{-4}$ \\
\hline & & 1.0 & $2.8 \times 10^{-4}$ \\
\hline & & 2.0 & $1.9 \times 10^{-4}$ \\
\hline & & 3.0 & $1.6 \times 10^{-4}$ \\
\hline & & 4.0 & $1.5 \times 10^{-4}$ \\
\hline
\end{tabular}




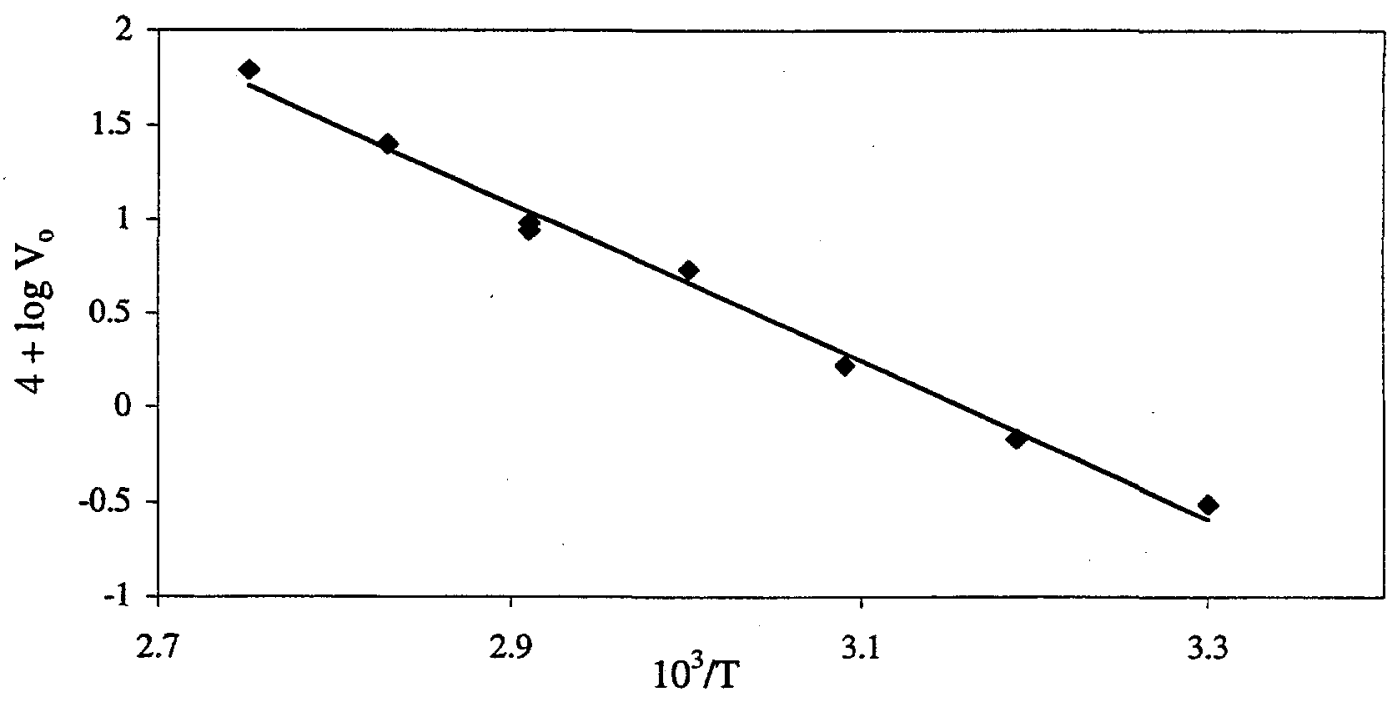

Figure 4.4. Effect of Temperature on the Initial Oxidation Rate of $0.02 \mathrm{M} \mathrm{Cr}$ (III) Hydroxide (compound II) by $0.04 \mathrm{M} \mathrm{H}_{2} \mathrm{O}_{2}$ in $0.5 \mathrm{M} \mathrm{NaOH}$

Table 4.3 presents the initial oxidation rates of the $\mathrm{Cr}$ (III) hydroxides aged at various elevated temperatures. It is evident that aging $\mathrm{Cr}$ (III) hydroxide under hydrothermal conditions sharply decreases its oxidation rate by $\mathrm{H}_{2} \mathrm{O}_{2}$. The lower oxidation rates may indicate that the more mineralized $\mathrm{Cr}$ (III) hydroxides are better catalysts for $\mathrm{H}_{2} \mathrm{O}_{2}$ decomposition.

Table 4.3. Initial Rate of $\mathrm{Cr}(\mathrm{III})$ Hydroxide Oxidation by $0.04 \mathrm{M} \mathrm{H}_{2} \mathrm{O}_{2}$

\begin{tabular}{|c|c|c|c|c|}
\hline $\begin{array}{l}\text { Compound } \\
\text { Number }\end{array}$ & $\begin{array}{c}\text { Coagulation } \\
\text { Temperature, }{ }^{\circ} \mathrm{C}\end{array}$ & {$[\mathrm{NaOH}], \mathrm{M}$} & $\mathrm{T},{ }^{\circ} \mathrm{C}$ & $\mathrm{V}_{0}$, moles/liter-minute \\
\hline II & 100 & \multirow[t]{10}{*}{0.2} & \multirow[t]{5}{*}{60} & $10.4 \times 10^{-4}$ \\
\hline $\mathrm{V}$ & 150 & & & $1.3 \times 10^{-4}$ \\
\hline VI & 200 & & & $1.8 \times 10^{-4}$ \\
\hline VII & 250 & & & $\mathrm{ND}^{(\mathrm{a})}$ \\
\hline VIII & 250 & & & $0.6 \times 10^{-4}$ \\
\hline II & 100 & & \multirow[t]{5}{*}{75} & $31 \times 10^{-4}$ \\
\hline $\mathrm{V}$ & 150 & & & $3.2 \times 10^{-4}$ \\
\hline VI & 200 & & & $4.3 \times 10^{-4}$ \\
\hline VII & 250 & & & $2.8 \times 10^{-4}$ \\
\hline VIII & 250 & & & $1.3 \times 10^{-4}$ \\
\hline II & 100 & \multirow[t]{10}{*}{2.0} & \multirow[t]{5}{*}{60} & $3.7 \times 10^{-4}$ \\
\hline $\mathrm{V}$ & 150 & & & $0.4 \times 10^{-4}$ \\
\hline VI & 200 & & & $0.5 \times 10^{-4}$ \\
\hline VII & 250 & & & $\mathrm{ND}^{(\mathrm{a})}$ \\
\hline VIII & 250 & & & $0.3 \times 10^{-4}$ \\
\hline II & 100 & & \multirow[t]{5}{*}{75} & $9.1 \times 10^{-4}$ \\
\hline $\mathrm{V}$ & 150 & & & $0.8 \times 10^{-4}$ \\
\hline VI & 200 & & & $1.4 \times 10^{-4}$ \\
\hline VII & 250 & & & $1.1 \times 10^{-4}$ \\
\hline VIII & 250 & & & $0.8 \times 10^{-4}$ \\
\hline
\end{tabular}




\section{2 $\mathrm{Cr}$ (III) Hydroxide Oxidation by $\mathrm{H}_{2} \mathrm{O}_{2}$ in the Presence of Some Catalysts}

The Hanford tank waste residues will have complex compositions even after the salts have been dissolved by water and the sludge has been leached with strongly alkaline solution. The residual sludges will contain mixtures of low-solubility d-element compounds that, in some cases, can be effective $\mathrm{H}_{2} \mathrm{O}_{2}$ decomposition catalysts in alkaline media. On the other hand, the sludge compounds and trace solution concentrations of the d-elements also might catalytically enhance $\mathrm{Cr}(\mathrm{III})$ oxidation by $\mathrm{H}_{2} \mathrm{O}_{2}$. Therefore, a series of experiments was performed to determine the effects of $\mathrm{Cu}$ (II), $\mathrm{Ni}$ (II), $\mathrm{Co}$ (II), and $\mathrm{Fe}$ (III) additions on the rate of $\mathrm{Cr}(\mathrm{III})$ reaction with $\mathrm{H}_{2} \mathrm{O}_{2}$. The experiments were conducted under conditions in which the initial oxidation rates, $\mathrm{V}_{\mathrm{o}}$, in the absence of catalysts were $1.9 \times 10^{-4}$ and $9.1 \times 10^{-4}$ moles/literminute at 50 and $70^{\circ} \mathrm{C}$, respectively.

As seen in Table 4.4, $\mathrm{Cr}$ (III) oxidation rates by $\mathrm{H}_{2} \mathrm{O}_{2}$ increase significantly in the presence of $10^{-5} \mathrm{M} \mathrm{Cu}(\mathrm{II})$ and $\mathrm{Co}(\mathrm{II})$. However, $\mathrm{Ni}$ (II) and $\mathrm{Fe}$ (III) at the same concentration have little effect on $\mathrm{V}_{\mathrm{D}}$. At higher (as much as $0.01 \mathrm{M}$ ) concentrations of all catalysts, the $\mathrm{H}_{2} \mathrm{O}_{2}$ decomposition becomes very fast,

Table 4.4. Oxidation of $0.02 \mathrm{M} \mathrm{Cr}_{2} \mathrm{O}_{3} \cdot 4 \mathrm{H}_{2} \mathrm{O}$ (compound II) in $0.5 \mathrm{M} \mathrm{NaOH}$ by $0.04 \mathrm{M} \mathrm{H}_{2} \mathrm{O}_{2}$ in the Presence of Catalysts ${ }^{(a)}$

\begin{tabular}{|c|c|c|c|c|c|}
\hline Catalyst & [Catalyst], $\mathbf{M}$ & $\mathrm{T},{ }^{\circ} \mathrm{C}$ & {$[\mathrm{Cr}(\mathrm{VI})]_{1}$} & {$[\mathrm{Cr}(\mathrm{VI})]_{2}$} & $\mathrm{~V}_{0}$, moles/liter-minute \\
\hline None & - & 50 & - & - & $1.9 \times 10^{-4}$ \\
\hline None & - & 70 & -- & -- & $9.1 \times 10^{-4}$ \\
\hline \multirow[t]{5}{*}{$\overline{\mathrm{Cu}}$} & $1 \times 10^{-5}$ & \multirow[t]{3}{*}{50} & $1.6 \times 10^{-3}$ & $1.9 \times 10^{-3}$ & $5.3 \times 10^{-4}$ \\
\hline & $3 \times 10^{-4}$ & & $1.56 \times 10^{-3}$ & $1.55 \times 10^{-3}$ & $>5.2 \times 10^{-4}$ \\
\hline & $1 \times 10^{-2}$ & & $1.0 \times 10^{-3}$ & $1.0 \times 10^{-3}$ & $>3.3 \times 10^{-4}$ \\
\hline & $3 \times 10^{-4}$ & \multirow[t]{2}{*}{70} & $1.2 \times 10^{-3}$ & $1.0 \times 10^{-3}$ & $>4.0 \times 10^{-4}$ \\
\hline & $1 \times 10^{-2}$ & & $0.3 \times 10^{-3}$ & $0.3 \times 10^{-3}$ & $>1.0 \times 10^{-4}$ \\
\hline \multirow[t]{6}{*}{$\mathrm{Ni}$} & $1 \times 10^{-5}$ & \multirow[t]{3}{*}{50} & $0.6 \times 10^{-3}$ & $1.0 \times 10^{-3}$ & $2.0 \times 10^{-4}$ \\
\hline & $3 \times 10^{-4}$ & & $0.7 \times 10^{-3}$ & $1.0 \times 10^{-3}$ & $>2.3 \times 10^{-4}$ \\
\hline & $1 \times 10^{-2}$ & & $0.2 \times 10^{-3}$ & $0.2 \times 10^{-3}$ & $>0.7 \times 10^{-4}$ \\
\hline & $1 \times 10^{-5}$ & \multirow[t]{3}{*}{70} & $2.3 \times 10^{-3}$ & $3.4 \times 10^{-3}$ & $7.7 \times 10^{-4}$ \\
\hline & $3 \times 10^{-4}$ & & $1.86 \times 10^{-3}$ & $3.64 \times 10^{-3}$ & $>6.2 \times 10^{-4}$ \\
\hline & $1 \times 10^{-2}$ & & $0.9 \times 10^{-3}$ & $1.0 \times 10^{-3}$ & $>3.0 \times 10^{-4}$ \\
\hline \multirow[t]{6}{*}{$\mathrm{Co}$} & $1 \times 10^{-5}$ & \multirow[t]{3}{*}{50} & $1.24 \times 10^{-3(b)}$ & $2.3 \times 10^{-3}$ & $6.2 \times 10^{-4}$ \\
\hline & $3 \times 10^{-4}$ & & $1.0 \times 10^{-3}$ & $1.3 \times 10^{-3}$ & $>3.4 \times 10^{-4}$ \\
\hline & $1 \times 10^{-2}$ & & $0.23 \times 10^{-3}$ & $0.23 \times 10^{-3}$ & $>0.8 \times 10^{-4}$ \\
\hline & $1 \times 10^{-5}$ & \multirow[t]{3}{*}{70} & $4.92 \times 10^{-3}$ & $6.0 \times 10^{-3}$ & $1.7 \times 10^{-3}$ \\
\hline & $3 \times 10^{-4}$ & & $3.23 \times 10^{-3}$ & $3.4 \times 10^{-3}$ & $>1.1 \times 10^{-3}$ \\
\hline & $1 \times 10^{-2}$ & & $0.58 \times 10^{-3}$ & $0.58 \times 10^{-3}$ & $>1.9 \times 10^{-4}$ \\
\hline \multirow[t]{6}{*}{$\overline{\mathrm{Fe}}$} & $1 \times 10^{-5}$ & \multirow[t]{3}{*}{50} & $0.56 \times 10^{-3}$ & $0.89 \times 10^{-3}$ & $1.9 \times 10^{-4}$ \\
\hline & $3 \times 10^{-4}$ & & $0.46 \times 10^{-3}$ & $0.6 \times 10^{-3}$ & $>1.5 \times 10^{-4}$ \\
\hline & $1 \times 10^{-2}$ & & $0.44 \times 10^{-3}$ & $0.5 \times 10^{-3}$ & $>1.5 \times 10^{-4}$ \\
\hline & $1 \times 10^{-5}$ & \multirow[t]{3}{*}{70} & $2.50 \times 10^{-3}$ & $4.4 \times 10^{-3}$ & $8.3 \times 10^{-4}$ \\
\hline & $3 \times 10^{-4}$ & & $1.40 \times 10^{-3}$ & $2.2 \times 10^{-3}$ & $>4.7 \times 10^{-4}$ \\
\hline & $1 \times 10^{-2}$ & & $0.83 \times 10^{-3}$ & $0.9 \times 10^{-3}$ & $>2.8 \times 10^{-4}$ \\
\hline \multicolumn{6}{|c|}{$\begin{array}{l}\text { (a) }[\mathrm{Cr}(\mathrm{VI})]_{1} \text { and }[\mathrm{Cr}(\mathrm{VI})]_{2} \text { are the concentrations of } \mathrm{Cr}(\mathrm{VI}) \text { after three and six } \\
\text { minutes, respectively. Initial rate calculated based on the first three minutes. } \\
\text { (b) In this test, [Cr(VI) }]_{1} \text { was at two minutes. }\end{array}$} \\
\hline
\end{tabular}


and $\mathrm{Cr}$ (III) oxidation practically ends after about three minutes' reaction with low yield of $\mathrm{Cr}$ (VI). This is shown by the low incremental concentrations of $\mathrm{Cr}(\mathrm{VI})$ dissolved after six minutes compared with the concentrations dissolved after three minutes (Table 4.4). Thus, with higher concentrations of candidate d-element catalysts, the initial oxidation rates of $\mathrm{Cr}(\mathrm{III}), \mathrm{V}_{\mathrm{o}}$, become less meaningful and are indicated by "greater than" values in Table 4.4.

Based on the observed parasitic loss of $\mathrm{H}_{2} \mathrm{O}_{2}$ in the presence of $\mathrm{Fe}$ (III) and other d-metals, the oxidative dissolution of $\mathrm{Cr}$ (III) hydroxides in the presence of significant concentrations of $\mathrm{Fe}$ (III) and other d-metals will be difficult to accomplish.

\subsection{Rate of Oxidation of Other $\mathrm{Cr}$ (III) Compounds by $\mathrm{H}_{2} \mathrm{O}_{2}$ in Alkaline Media}

Data in Table 4.5 show that the initial rates of $\mathrm{Cr}$ (VI) production are relatively high for the reaction of $\mathrm{Ni}$ (II) chromite and mixed $\mathrm{Fe}(\mathrm{III}) / \mathrm{Cr}(\mathrm{III})$ hydroxide compounds, aged at $100^{\circ} \mathrm{C}$, with hydrogen peroxide. The same compounds aged at $200^{\circ} \mathrm{C}$ for 20 hours react very slowly with $\mathrm{H}_{2} \mathrm{O}_{2}$. The catalytic decomposition of $\mathrm{H}_{2} \mathrm{O}_{2}$ also increases significantly for the aged compounds, especially at high $\mathrm{NaOH}$ concentration.

Table 4.5. Initial Oxidation Rate of Some Cr(III) Compounds by $0.04 \mathrm{M} \mathrm{H}_{2} \mathrm{O}_{2}$

\begin{tabular}{|c|c|c|c|c|}
\hline \multirow{2}{*}{$\begin{array}{l}\text { Compound } \\
\text { Number }^{(2)}\end{array}$} & \multicolumn{2}{|c|}{ Temperature, ${ }^{\circ} \mathrm{C}$} & \multirow[b]{2}{*}[\mathrm{NaOH}]{, $\mathrm{M}$} & \multirow[b]{2}{*}{$\mathrm{V}_{\mathrm{o}}$, moles/liter-minute } \\
\hline & Aging & Dissolution & & \\
\hline $\mathrm{X}$ & \multirow[t]{2}{*}{100} & \multirow{8}{*}{60} & \multirow{4}{*}{0.2} & $3.1 \times 10^{-4}$ \\
\hline XII & & & & $7.0 \times 10^{-4}$ \\
\hline$\overline{X I}$ & \multirow[t]{2}{*}{200} & & & $0.5 \times 10^{-4}$ \\
\hline XIII & & & & $1.2 \times 10^{-4}$ \\
\hline $\bar{X}$ & \multirow[t]{2}{*}{100} & & \multirow{4}{*}{2.0} & $1.3 \times 10^{-4}$ \\
\hline XII & & & & $4.0 \times 10^{-4}$ \\
\hline $\mathrm{XI}$ & \multirow[t]{2}{*}{200} & & & $0.2 \times 10^{-4}$ \\
\hline XIII & & & & $0.6 \times 10^{-4}$ \\
\hline $\mathrm{X}$ & \multirow[t]{2}{*}{100} & \multirow{8}{*}{75} & \multirow{4}{*}{0.2} & $6.1 \times 10^{-4}$ \\
\hline $\mathrm{XII}$ & & & & $11.4 \times 10^{-4}$ \\
\hline $\mathrm{XI}$ & \multirow[t]{2}{*}{200} & & & $1.3 \times 10^{-4}$ \\
\hline XIII & & & & $2.0 \times 10^{-4}$ \\
\hline $\mathrm{X}$ & \multirow[t]{2}{*}{100} & & \multirow{4}{*}{2.0} & $2.5 \times 10^{-4}$ \\
\hline $\mathrm{XII}$ & & & & $6.1 \times 10^{-4}$ \\
\hline $\mathrm{XI}$ & \multirow[t]{2}{*}{200} & & & $0.6 \times 10^{-4}$ \\
\hline XIII & & & & $1.2 \times 10^{-4}$ \\
\hline \multicolumn{3}{|c|}{ (a) $\begin{array}{r}\mathrm{X}-\mathrm{NiCr}_{2} \mathrm{O}_{4} \cdot 5 \mathrm{H}_{2} \mathrm{O}\left(\mathrm{T}_{\mathrm{c}}=100^{\circ} \mathrm{C}\right) \\
\mathrm{XI}-\mathrm{NiCr}_{2} \mathrm{O}_{4} \cdot 4 \mathrm{H}_{2} \mathrm{O}\left(\mathrm{T}_{\mathrm{c}}=200^{\circ} \mathrm{C}\right)\end{array}$} & \multicolumn{2}{|c|}{$\begin{array}{l}\mathrm{XII}-\mathrm{Fe}_{0.67} \mathrm{Cr}_{1.33} \mathrm{O}_{3} \cdot 2 \mathrm{H}_{2} \mathrm{O}\left(\mathrm{T}_{\mathrm{c}}=100^{\circ} \mathrm{C}\right) \\
\mathrm{XIII}-\mathrm{Fe}_{0.67} \mathrm{Cr}_{1.33} \mathrm{O}_{3} \cdot 2 \mathrm{H}_{2} \mathrm{O}\left(\mathrm{T}_{\mathrm{c}}=200^{\circ} \mathrm{C}\right)\end{array}$} \\
\hline
\end{tabular}




\section{4 $\mathrm{H}_{2} \mathrm{O}_{2}$ Consumption in the Complete Oxidation of $\mathrm{Cr}(\mathrm{III})$ Hydroxides}

The theoretical consumption of hydrogen peroxide by oxidative dissolution of $\mathrm{Cr}(\mathrm{III})$ hydroxides, described by the following reaction:

$$
\mathrm{Cr}_{2} \mathrm{O}_{3} \cdot \mathrm{nH}_{2} \mathrm{O}+3 \mathrm{H}_{2} \mathrm{O}_{2}+4 \mathrm{OH}^{-} \rightarrow 2 \mathrm{CrO}_{4}{ }^{2-}+(\mathrm{n}+5) \mathrm{H}_{2} \mathrm{O}
$$

is 1.5 moles per mole of $\mathrm{Cr}$ (III). The same $\mathrm{H}_{2} \mathrm{O}_{2}$ consumption may be expected for both $\mathrm{Ni}$ (II) chromite and $\mathrm{Cr}$ (III)/Fe(III) mixed hydroxide:

$$
\begin{gathered}
\mathrm{NiCr}_{2} \mathrm{O}_{4} \cdot \mathrm{nH}_{2} \mathrm{O}+3 \mathrm{H}_{2} \mathrm{O}_{2}+4 \mathrm{OH}^{-} \rightarrow 2 \mathrm{CrO}_{4}{ }^{2-}+\mathrm{Ni}(\mathrm{OH})_{2}+(\mathrm{n}+4) \mathrm{H}_{2} \mathrm{O} \\
3 \mathrm{Fe}_{0.67} \mathrm{Cr}_{1.33} \mathrm{O}_{3} \cdot 2 \mathrm{H}_{2} \mathrm{O}+6 \mathrm{H}_{2} \mathrm{O}_{2}+8 \mathrm{OH}^{-} \rightarrow 4 \mathrm{CrO}_{4}{ }^{2-}+2 \mathrm{Fe}(\mathrm{OH})_{3}+13 \mathrm{H}_{2} \mathrm{O}
\end{gathered}
$$

However, the actual $\mathrm{H}_{2} \mathrm{O}_{2}$ consumption for $\mathrm{Cr}$ (III) oxidation is significantly higher because of the catalytic decomposition of the oxidant. The relative contribution of the latter process depends on the $\mathrm{Cr}$ (III) oxidation conditions. As seen in Table 4.6, with stepwise addition of $\mathrm{H}_{2} \mathrm{O}_{2}$ solution $(0.05 \mathrm{~mL}$ added every three minutes), the fraction of oxidant lost to catalytic decomposition decreases with increasing temperature. Increasing $\mathrm{NaOH}$ concentration increases the catalyst-mediated loss of $\mathrm{H}_{2} \mathrm{O}_{2}$. Therefore, the oxidative dissolution of $\mathrm{Cr}(\mathrm{III})$ hydroxide by $\mathrm{H}_{2} \mathrm{O}_{2}$ should be conducted at the lowest possible alkali concentration and at temperatures close to $100^{\circ} \mathrm{C}$. In choosing the initial $\mathrm{NaOH}$ concentration, it also is necessary to account for the consumption of 2 moles $\mathrm{OH}^{-}$per mole of $\mathrm{Cr}(\mathrm{III})$ to be oxidized.

The consumption of $\mathrm{H}_{2} \mathrm{O}_{2}$ in the oxidative dissolution of $\mathrm{Cr}(\mathrm{III})$ hydroxide increases sharply in the presence of $\mathrm{Fe}$ (III) (Table 4.7). The influence of $\mathrm{Ni}$ (II) on the consumption of $\mathrm{H}_{2} \mathrm{O}_{2}$ for $\mathrm{Cr}$ (III) hydroxide dissolution is much lower than that of $\mathrm{Fe}(\mathrm{III})$. The test results presented in Table 4.8 show that $\mathrm{H}_{2} \mathrm{O}_{2}$ is. not effective for alkaline oxidative dissolution of $\mathrm{Cr}(\mathrm{III})$ hydroxides aged under hydrothermal conditions, even in the absence of additional catalysts. The completeness of $\mathrm{Cr}(\mathrm{III})$ oxidation generally decreases

\begin{tabular}{|c|c|c|c|c|}
\hline$[\mathrm{Cr}(\mathrm{III})], \mathrm{M}$ & {$[\mathrm{NaOH}], \mathrm{M}$} & $\mathrm{T},{ }^{\circ} \mathrm{C}$ & {$\left[\mathrm{H}_{2} \mathrm{O}_{2}\right], \mathrm{M}$} & $\mathrm{H}_{2} \mathrm{O}_{2} / \mathrm{Cr}$ (III) mole ratio \\
\hline \multirow[t]{5}{*}{0.02} & \multirow[t]{5}{*}{0.3} & 50 & \multirow[t]{5}{*}{1.0} & 6.5 \\
\hline & & 60 & & 5.0 \\
\hline & & 75 & & 3.1 \\
\hline & & 85 & & 2.8 \\
\hline & & 90 & & 2.6 \\
\hline 0.02 & 1.0 & \multirow[t]{4}{*}{70} & 1.0 & 4.0 \\
\hline 0.05 & 2.0 & & 2.0 & 4.0 \\
\hline 0.10 & 2.0 & & 2.0 & 3.2 \\
\hline 0.20 & 2.0 & & 4.0 & 3.1 \\
\hline
\end{tabular}
with increasing aging temperature.

Table 4.6. Consumption of $\mathrm{H}_{2} \mathrm{O}_{2}$ for $\mathrm{Cr}$ (III) Hydroxide (compound II) Oxidation in Alkaline Solutions ${ }^{\text {(a) }}$ 
Table 4.7. Consumption of $\mathrm{H}_{2} \mathrm{O}_{2}$ for Complete $\mathrm{Cr}$ (III) Hydroxide (compound II) Oxidation in $70^{\circ} \mathrm{C} 2 \mathrm{M} \mathrm{NaOH}$ in the Presence of Catalysts ${ }^{(\mathrm{a})}$

\begin{tabular}{|c|c|c|c|c|}
\hline Catalyst & {$[$ Catalyst], $\mathrm{M}$} & {$[\mathrm{Cr}(\mathrm{Im})]_{0}, \mathrm{M}$} & {$\left[\mathrm{H}_{2} \mathrm{O}_{2}\right], \mathrm{M}$} & $\mathrm{H}_{2} \mathrm{O}_{2} / \mathrm{Cr}(\mathrm{II})$ mole ratio \\
\hline \multirow{4}{*}{$\mathrm{Fe}(\mathrm{III})$} & $1 \times 10^{-4}$ & 0.02 & 1.0 & 5.0 \\
\cline { 2 - 5 } & $1 \times 10^{-2}$ & 0.02 & 1.0 & 15 \\
\cline { 2 - 5 } & $2 \times 10^{-2}$ & 0.02 & 1.0 & $>20$ \\
\cline { 2 - 5 } & $1 \times 10^{-4}$ & 0.05 & 2.0 & 4.0 \\
\cline { 2 - 5 } & $1 \times 10^{-2}$ & 0.05 & 2.0 & 8.0 \\
\hline \multirow{3}{*}{$\mathrm{Ni}(\mathrm{II})$} & $1 \times 10^{-4}$ & 0.02 & 1.0 & 3.7 \\
\cline { 2 - 5 } & $1 \times 10^{-2}$ & 0.015 & 1.0 & 5.1 \\
\cline { 2 - 5 } & $1 \times 10^{-4}$ & 0.05 & 2.0 & 4.0 \\
\cline { 2 - 5 } & $1 \times 10^{-2}$ & 0.05 & 2.0 & 6.1 \\
\cline { 2 - 5 } & \multicolumn{3}{|c|}{} \\
\hline (a) $10 \mathrm{~mL}$ of suspension.
\end{tabular}

Table 4.8. Oxidation of $0.022 \mathrm{M}$ Aged $\mathrm{Cr}$ (III) Hydroxides in $0.3 \mathrm{M} \mathrm{NaOH}$ by $\mathrm{H}_{2} \mathrm{O}_{2}{ }^{(a, b)}$

\begin{tabular}{|c|c|c|c|c|}
\hline \multirow{2}{*}{$\begin{array}{l}\text { Compound } \\
\text { Number }\end{array}$} & \multicolumn{2}{|c|}{ Temperature, ${ }^{\circ} \mathrm{C}$} & \multirow{2}{*}{$\begin{array}{c}{[\mathrm{Cr}(\mathrm{VI})],} \\
\mathrm{M}\end{array}$} & \multirow{2}{*}{$\begin{array}{c}\text { Cr(VI) Yield, } \\
\%\end{array}$} \\
\hline & Aging & Dissolution & & \\
\hline $\bar{V}$ & 150 & \multirow[t]{3}{*}{70} & $7.9 \times 10^{-3}$ & 50 \\
\hline VI & 200 & & $10.8 \times 10^{-3}$ & 69 \\
\hline VIII & 250 & & $6.5 \times 10^{-3}$ & 41 \\
\hline $\mathrm{V}$ & 150 & \multirow[t]{3}{*}{85} & $12.5 \times 10^{-3}$ & 80 \\
\hline $\mathrm{VI}$ & 200 & & $10.4 \times 10^{-3}$ & 66 \\
\hline VIII & 250 & & $6.7 \times 10^{-3}$ & 42 \\
\hline $\begin{array}{l}\text { (b) Stepwise ad } \\
1 \mathrm{M} \mathrm{H}_{2} \mathrm{O}_{2}: \quad[\sim 1\end{array}$ & 1 & r( & & \\
\hline
\end{tabular}

Significant catalytic loss of $\mathrm{H}_{2} \mathrm{O}_{2}$ was also observed in the oxidative reaction of $\mathrm{H}_{2} \mathrm{O}_{2}$ with $\mathrm{NiCr}_{2} \mathrm{O}_{4} \cdot \mathrm{nH}_{2} \mathrm{O}$ and mixed $\mathrm{Cr}(\mathrm{III})$ and $\mathrm{Fe}(\mathrm{III})$ hydroxides (Table 4.9). Especially low chromium leaching took place for the compounds aged hydrothermally at $200^{\circ} \mathrm{C}$.

Table 4.9. Interaction of $\mathrm{NiCr}_{2} \mathrm{O}_{4} \cdot \mathrm{nH}_{2} \mathrm{O}$ (compounds $\mathrm{X}$ and $\mathrm{XI}$ ) and $\mathrm{Fe}_{0.67} \mathrm{Cr}_{1.33} \mathrm{O}_{3} \cdot 2 \mathrm{H}_{2} \mathrm{O}$ (compounds XII and XIII) with $1 \mathrm{M} \mathrm{H}_{2} \mathrm{O}_{2}$ in $0.3 \mathrm{M} \mathrm{NaOH}^{(\mathrm{a}, b)}$

\begin{tabular}{|c|c|c|c|c|c|}
\hline \multirow{2}{*}{$\begin{array}{c}\text { Compound } \\
\text { Number }\end{array}$} & \multicolumn{2}{|c|}{ Temperature, ${ }^{\circ} \mathrm{C}$} & \multirow[b]{2}{*}[\mathrm{Cr}(\mathrm{III})]{$_{0}, \mathrm{M}$} & \multicolumn{2}{|c|}{ Cr(VI) Yield, \% } \\
\hline & Aging & Dissolution & & $1 \mathrm{~mL} 1 \mathrm{M} \mathrm{H}_{2} \mathrm{O}_{2}$ & $2 \mathrm{~mL} 1 \mathrm{M} \mathrm{H}_{2} \mathrm{O}_{2}$ \\
\hline $\mathrm{X}$ & 100 & \multirow[t]{4}{*}{70} & $1.4 \times 10^{-2}$ & 65 & 82 \\
\hline XI & 200 & & $2.9 \times 10^{-2}$ & 7 & 11 \\
\hline XII & 100 & & $3.0 \times 10^{-2}$ & 52 & 60 \\
\hline XIII & 200 & & $2.9 \times 10^{-2}$ & 9 & 13 \\
\hline $\mathrm{X}$ & 100 & \multirow[t]{4}{*}{85} & $2.8 \times 10^{-2}$ & 89 & $\geq 95$ \\
\hline XI & 200 & & $3.0 \times 10^{-2}$ & 10 & 18 \\
\hline XII & 100 & & $2.9 \times 10^{-2}$ & 62 & 84 \\
\hline XIII & 200 & & $3.0 \times 10^{-2}$ & 11 & 16 \\
\hline
\end{tabular}




\subsection{Oxidative Alkaline Dissolution of Chromium(III) Compounds by Persulfate}

\subsection{Data on the Kinetics and Mechanism of $\mathrm{Cr}$ (III) Hydroxide Oxidation}

Studies were conducted to determine the stoichiometry of $\mathrm{Cr}$ (III) oxidation by persulfate. Results in Table 5.1 show that the complete oxidative dissolution of $\mathrm{Cr}_{2} \mathrm{O}_{3} \cdot 4 \mathrm{H}_{2} \mathrm{O}$ (compound II) is observed only at persulfate $\left(\mathrm{S}_{2} \mathrm{O}_{8}{ }^{2-}\right)$ to $\mathrm{Cr}(\mathrm{III})$ molar ratios greater than 1.5. At lower ratios, part of the solid phase remains in the suspension with the yield of $\mathrm{Cr}(\mathrm{VI})$ in solution corresponding to an $\mathrm{S}_{2} \mathrm{O}_{8}{ }^{2-}: \mathrm{Cr}(\mathrm{VI})$ mole ratio close to 1.5. Thus, the stoichiometry of the oxidation of compound II by persulfate in $\mathrm{NaOH}$ solutions is expressed by the equation:

$$
\mathrm{Cr}_{2} \mathrm{O}_{3} \cdot 4 \mathrm{H}_{2} \mathrm{O}+3 \mathrm{~S}_{2} \mathrm{O}_{8}{ }^{2-}+10 \mathrm{OH}^{-} \rightarrow 2 \mathrm{CrO}_{4}{ }^{2-}+6 \mathrm{SO}_{4}{ }^{2-}+9 \mathrm{H}_{2} \mathrm{O}
$$

Typical kinetic curves of the reaction of $\mathrm{Cr}$ (III) hydroxide with persulfate in $\mathrm{NaOH}$ solutions are presented in Figure 5.1. Such curves were used to determine the initial reaction rates (that is, $\mathrm{V}_{0}=$ $\mathrm{d}[\mathrm{Cr}(\mathrm{VI})] / \mathrm{d} \tau$ as $\tau \rightarrow 0$ ). Initial reaction rates may be used to establish reaction orders in terms of reactant concentrations and to reach conclusions on the reaction mechanism.

Initial reaction rates, $\mathrm{V}_{\mathrm{o}}$, for suspensions of different compositions are given in Table 5.2. The data show that the experimental rates of $\mathrm{Cr}$ (III) oxidation in alkaline solutions at less than $70^{\circ} \mathrm{C}$ are significantly higher than the reported rates of $\mathrm{S}_{2} \mathrm{O}_{8}{ }^{2-}$ thermal decomposition [Kolthoff and Miller 1951]. On this basis, $\mathrm{Cr}(\mathrm{III})$ hydroxide appears to react directly with $\mathrm{S}_{2} \mathrm{O}_{8}{ }^{2-}$. However, at greater than $80^{\circ} \mathrm{C}$, the rate of $\mathrm{S}_{2} \mathrm{O}_{8}{ }^{2-}$ thermal decomposition exceeds that of $\mathrm{Cr}$ (III) oxidation (Table 5.3). Under such conditions, the ion radical $\mathrm{SO}_{4}^{-}$can participate in reactions to form $\mathrm{Cr}(\mathrm{VI})$.

The data of Table 5.2 also were used to estimate the reaction orders in terms of $\mathrm{Cr}$ (III) and $\mathrm{S}_{2} \mathrm{O}_{8}{ }^{2-}$ concentrations. Both reaction orders are $\sim 1$ as shown by the linear dependencies of $\mathrm{V}_{0}$ on $\mathrm{Cr}(\mathrm{III})$ and $\mathrm{S}_{2} \mathrm{O}_{8}{ }^{2-}$ concentrations (in logarithmic coordinates) with slopes of $\sim 1$ (Figures 5.2 and 5.3).

Table 5.1. Yield of $\mathrm{Cr}(\mathrm{VI})$ after Completion of the $\mathrm{Cr}_{2} \mathrm{O}_{3} \cdot 4 \mathrm{H}_{2} \mathrm{O}$ (compound II) Reaction with Persulfate

\begin{tabular}{|c|c|c|c|c|c|c|c|}
\hline \multicolumn{3}{|c|}{ Initial composition, $\mathbf{M}$} & \multirow{2}{*}{$\begin{array}{l}{\left[\mathrm{S}_{2} \mathrm{O}_{8}{ }^{2}\right]_{0}} \\
{[\mathrm{Cr}(\mathrm{III})]_{0}}\end{array}$} & \multicolumn{2}{|r|}{ Conditions } & \multirow{2}{*}{$\begin{array}{c}\text { [Cr(VI)] } \\
\mathrm{M}\end{array}$} & \multirow{2}{*}{$\begin{array}{l}{\left[\mathrm{S}_{2} \mathrm{O}_{8}{ }^{2-}\right]_{0}} \\
{[\mathrm{CrVI}]^{(\mathrm{a})}}\end{array}$} \\
\hline$[\mathrm{NaOH}]_{0}$ & {$[\mathrm{Cr}(\mathrm{III})]_{0}$} & {$\left[\mathrm{~S}_{2} \mathrm{O}_{8}{ }^{2-}\right]_{0}$} & & $\mathrm{~T},{ }^{\circ} \mathrm{C}$ & Completion, min. & & \\
\hline 3.0 & 0.056 & 0.2 & 3.57 & 71.0 & 25 & 0.055 & 3.64, complete \\
\hline 0.5 & 0.039 & 0.2 & 5.13 & 80.0 & 35 & 0.040 & 5.0, complete \\
\hline 2.5 & 23 & 1 & 1 & 71.0 & 81 & 57 & 1.49 , \\
\hline 2.5 & 0.128 & 0.15 & 1.17 & 71.0 & 65 & 0.096 & 1.56 , incomplete \\
\hline 2.5 & 0.136 & 0.15 & 1.10 & 71.0 & 75 & 0.098 & 1.53 , incomplete \\
\hline
\end{tabular}

(a) Data in this column indicate whether complete or incomplete dissolution of the $\mathrm{Cr}$ (III) compound was observed. 


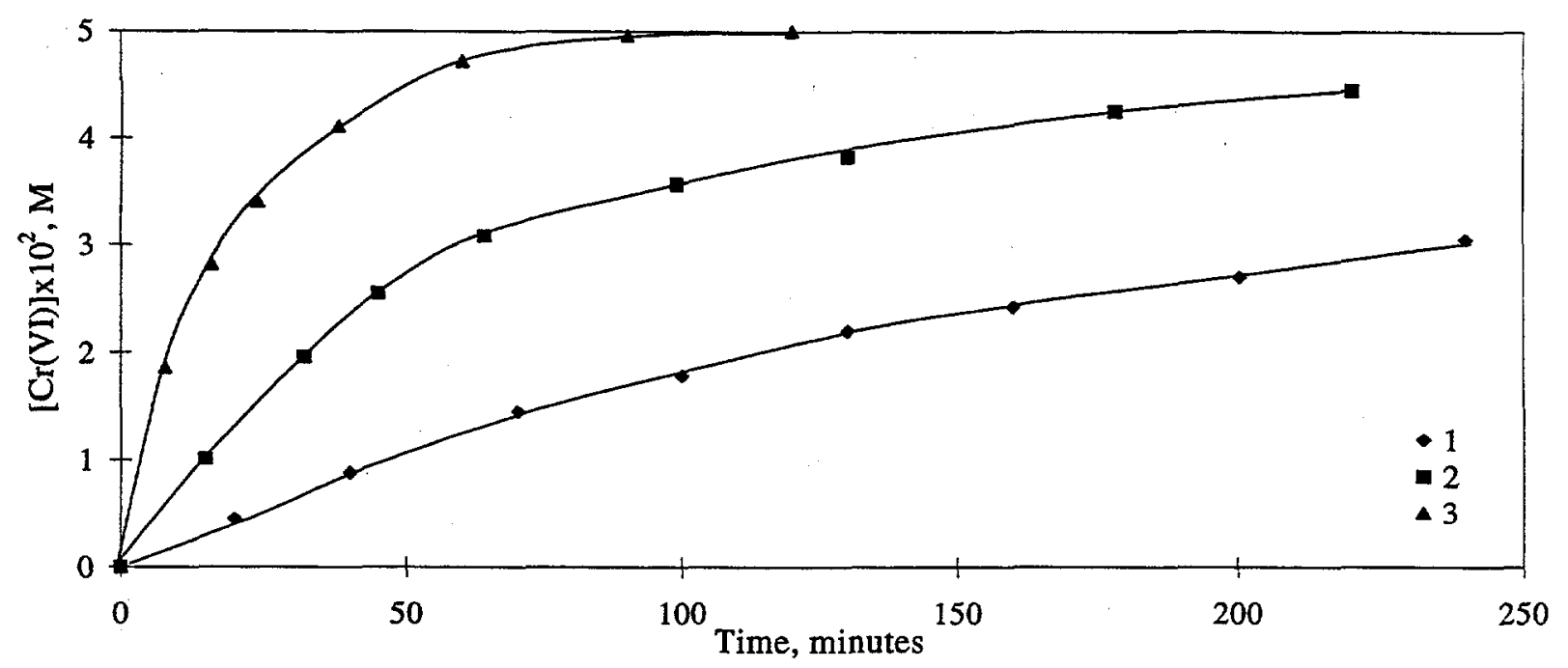

Figure 5.1. Kinetics of Oxidation of $0.05 \mathrm{M} \mathrm{Cr}$ (III) Hydroxide (compound II) by $0.2 \mathrm{M} \mathrm{S}_{2} \mathrm{O}_{8}{ }^{2-}$ in $0.5 \mathrm{M} \mathrm{NaOH}: 1-41.5^{\circ} \mathrm{C} ; 2-60.5^{\circ} \mathrm{C} ; 3-80.0^{\circ} \mathrm{C}$

Table 5.2. Effect of Composition on the Initial Rates of $\mathrm{Cr}$ (III) Hydroxide Oxidation by $\mathrm{S}_{2} \mathrm{O}_{8}{ }^{2-}$

\begin{tabular}{|c|c|c|c|c|c|}
\hline Compound Number & {$[\mathrm{NaOH}]_{0}, \mathrm{M}$} & $\mathrm{T},{ }^{\circ} \mathrm{C}$ & {$[\mathrm{Cr}(\mathrm{III})]_{0}, \mathrm{M}$} & {$\left[\mathrm{S}_{2} \mathrm{O}_{8}^{2-}\right]_{0}, \mathrm{M}$} & $\mathrm{V}_{\mathrm{o}}$, moles/liter-minute \\
\hline \multirow[t]{5}{*}{ II } & \multirow[t]{5}{*}{0.5} & \multirow[t]{5}{*}{71.0} & 0.014 & \multirow[t]{5}{*}{0.20} & $0.50 \times 10^{-3}$ \\
\hline & & & 0.024 & & $0.94 \times 10^{-3}$ \\
\hline & & & 0.039 & & $1.23 \times 10^{-3}$ \\
\hline & & & 0.050 & & $1.75 \times 10^{-3}$ \\
\hline & & & 0.056 & & $2.10 \times 10^{-3}$ \\
\hline \multirow[t]{4}{*}{ m } & \multirow[t]{4}{*}{2.0} & \multirow[t]{4}{*}{50.0} & \multirow[t]{4}{*}{0.034} & 0.05 & $0.40 \times 10^{-3}$ \\
\hline & & & & 0.10 & $0.74 \times 10^{-3}$ \\
\hline & & & & 0.20 & $1.40 \times 10^{-3}$ \\
\hline & & & & 0.40 & $3.30 \times 10^{-3}$ \\
\hline
\end{tabular}

Table 5.3. Effect of Temperature and $\mathrm{NaOH}$ Concentration on the Initial Rate of $0.05 \mathrm{M} \mathrm{Cr}$ (III) (compound II) Oxidation by $0.2 \mathrm{M} \mathrm{S}_{2} \mathrm{O}_{8}{ }^{2-}$

\begin{tabular}{|c|c|c|}
\hline $\mathrm{T},{ }^{\circ} \mathrm{C}$ & {$[\mathrm{NaOH}]_{0}, \mathrm{M}$} & $\mathrm{V}_{\mathrm{o}}$, moles/liter-minute \\
\hline \multirow[t]{6}{*}{71.0} & 0.1 & $0.54 \times 10^{-3}$ \\
\hline & 0.2 & $0.98 \times 10^{-3}$ \\
\hline & 0.5 & $1.84 \times 10^{-3}$ \\
\hline & 1.0 & $3.5 \times 10^{-3}$ \\
\hline & 2.5 & $10.0 \times 10^{-3}$ \\
\hline & 3.0 & $15.0 \times 10^{-3}$ \\
\hline 41.5 & \multirow[t]{6}{*}{0.5} & $0.27 \times 10^{-3}$ \\
\hline 41.5 & & $0.34 \times 10^{-3}$ \\
\hline 60.5 & & $0.79 \times 10^{-3}$ \\
\hline 71.0 & & $1.75 \times 10^{-3}$ \\
\hline 80.0 & & $2.44 \times 10^{-3}$ \\
\hline 95.0 & & $4.80 \times 10^{-3}$ \\
\hline
\end{tabular}




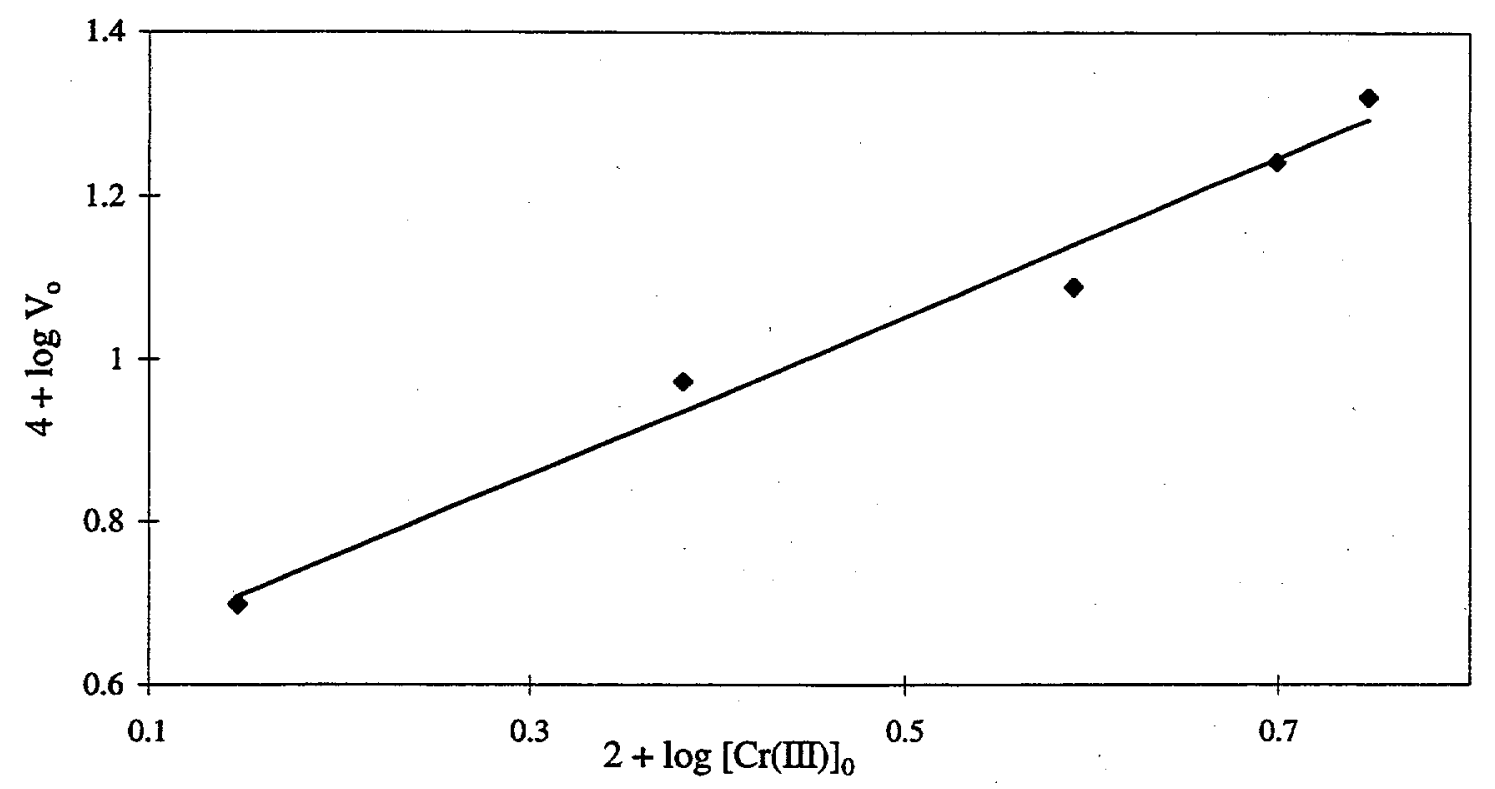

Figure 5.2. Effect of Initial $\mathrm{Cr}$ (III) Concentration on the Initial Oxidation Rate of $\mathrm{Cr}$ (III) Hydroxide (compound II) by $0.2 \mathrm{M} \mathrm{S}_{2} \mathrm{O}_{8}{ }^{2-}$ at $71^{\circ} \mathrm{C}$ in $0.5 \mathrm{M} \mathrm{NaOH}$

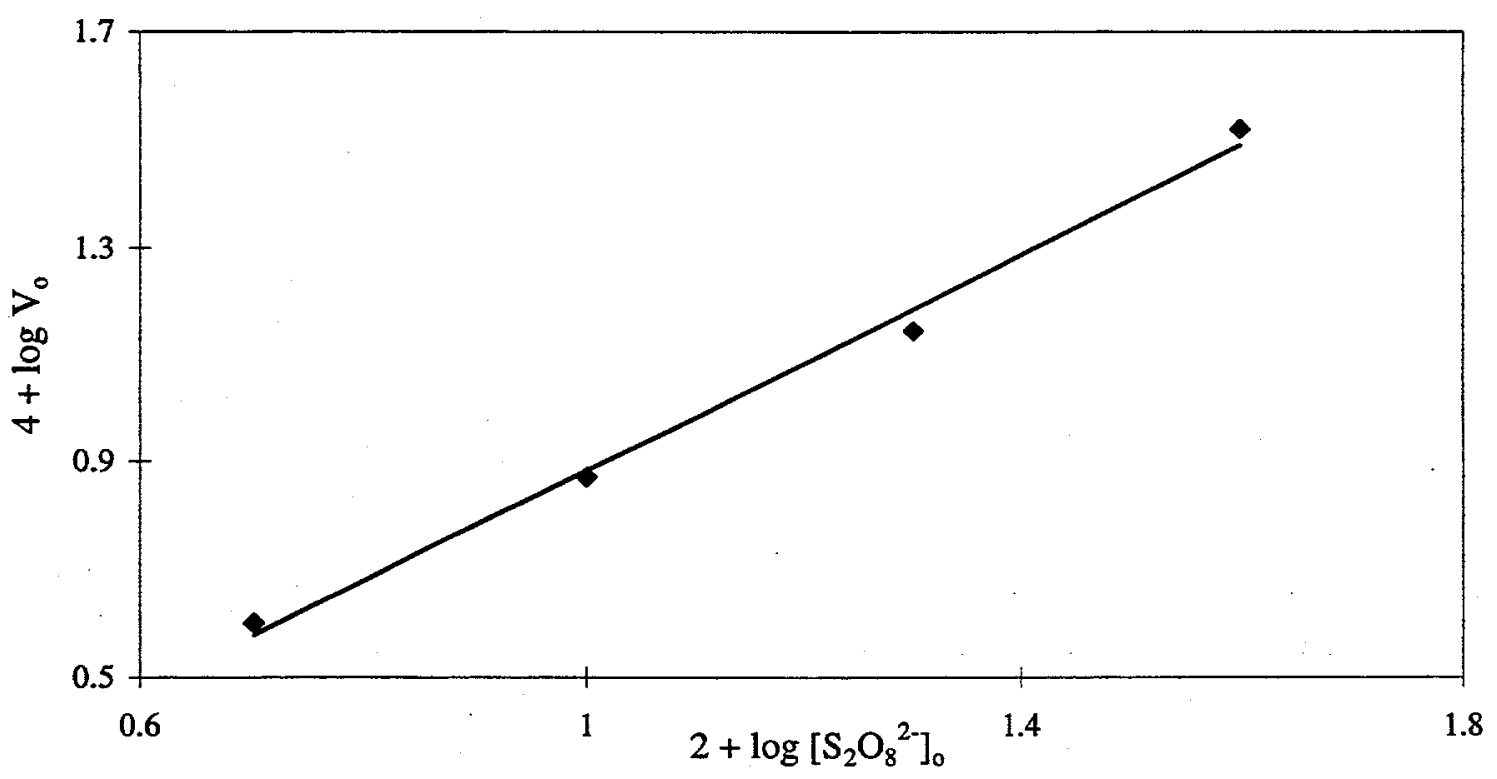

Figure 5.3. Effect of Initial $\mathrm{S}_{2} \mathrm{O}_{8}{ }^{2-}$ Concentration on the Initial Oxidation Rate of $0.034 \mathrm{M} \mathrm{Cr}$ (III) Hydroxide (compound III) in $2 \mathrm{M} \mathrm{NaOH}$ at $50^{\circ} \mathrm{C}$

The effects of temperature and $\mathrm{NaOH}$ concentration on the initial reaction rates, $\mathrm{V}_{\mathrm{o}}$, are presented in Table 5.3. These data, shown in Figure 5.4, indicate that the dependence of $\log \left(\mathrm{V}_{0}\right)$ on inverse absolute temperature is linear with slope corresponding to a formal activation energy, $E_{2}$, of $53 \mathrm{~kJ} / \mathrm{mole}$. The dependence of $\mathrm{V}_{\mathrm{o}}$ on $\mathrm{NaOH}$ concentration in the range 0.1-3 $\mathrm{M}$ in logarithmic coordinates (Figure 5.5) follows a straight line with the slope about 1. The deviation of experimental points from this dependence may be caused by the deviation of $\mathrm{NaOH}$ behavior from ideality with increasing alkali concentration. 


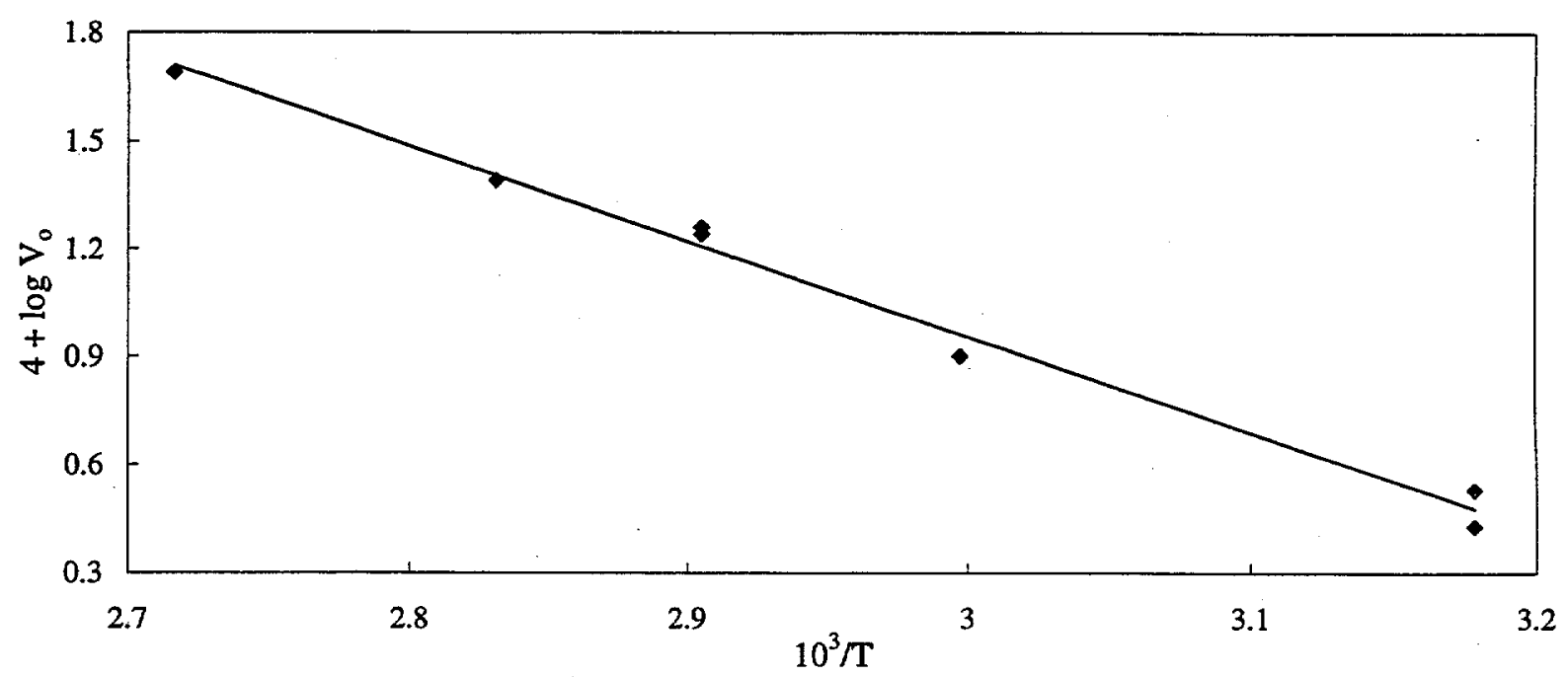

Figure 5.4. Effect of Temperature on the Initial Oxidation Rate of $0.05 \mathrm{M} \mathrm{Cr}$ (III) Hydroxide (compound II) by $0.2 \mathrm{M} \mathrm{S}_{2} \mathrm{O}_{8}{ }^{2-}$ in $0.5 \mathrm{M} \mathrm{NaOH}$

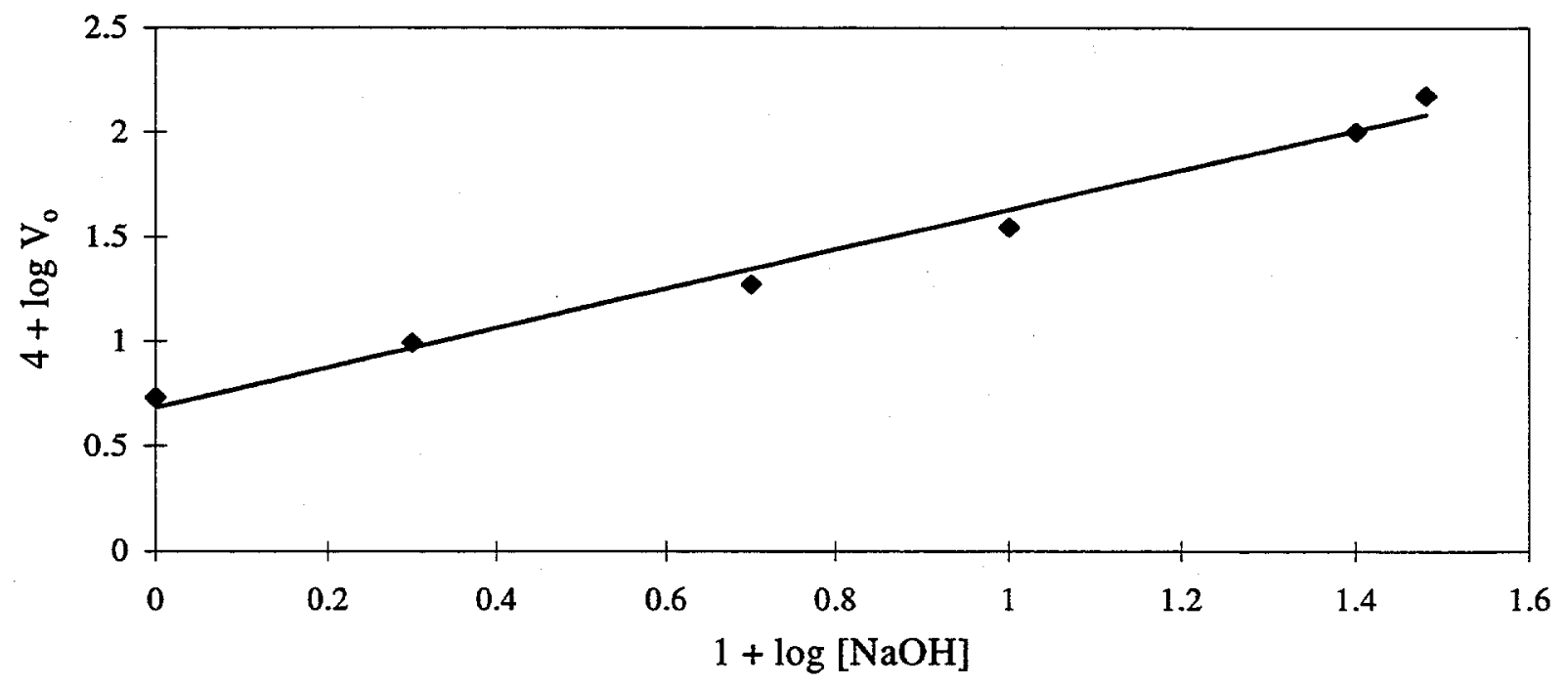

Figure 5.5. Effect of $\mathrm{NaOH}$ Concentration on the Initial Oxidation Rate of $0.05 \mathrm{M} \mathrm{Cr}$ (III) Hydroxide (compound II) by $0.2 \mathrm{M} \mathrm{S}_{2} \mathrm{O}_{8}{ }^{2-}$ at $71^{\circ} \mathrm{C}$

Based on these results, a kinetic equation for $\mathrm{Cr}(\mathrm{III})$ hydroxide oxidation by persulfate in $\mathrm{NaOH}$ (i.e., the decrease in $\mathrm{Cr}(\mathrm{III})$ concentration with time, $\tau$ ) can be written as

$$
\mathrm{d}[\mathrm{Cr}(\mathrm{III})] / \mathrm{d} \tau=\mathrm{dC} / \mathrm{d} \tau=-\mathrm{kCC} \mathrm{C}_{2}
$$

where $\mathrm{C}, \mathrm{C}_{1}$, and $\mathrm{C}_{2}$ are the respective $\mathrm{Cr}$ (III), $\mathrm{S}_{2} \mathrm{O}_{8}{ }^{2-}$, and $\mathrm{NaOH}$ concentrations. Average values of $\mathrm{k}$ were estimated to be $0.1,0.18$, and $0.35 \mathrm{M}^{-2} \mathrm{~min}^{-1}$ at 50,60 and $70^{\circ} \mathrm{C}$, respectively.

According to the stoichiometry expressed in equation (1), it is clear that

$$
C_{1}=C_{1 i}-1.5\left(C_{i}-C\right)=a+1.5 C \text {, where } a=C_{1 i}-1.5 C_{i}
$$


and

$$
C_{2}=C_{2 i}-5\left(C_{i}-C\right)=b+5 C, \text { where } b=C_{2 i}-5 C_{i}
$$

Here $C_{i}, C_{1 i}$, and $C_{2 i}$ are initial values of $C, C_{1}$, and $C_{2}$, respectively. Therefore,

$$
\mathrm{dC} / \mathrm{d} \tau=-\mathrm{kC}(\mathrm{a}+1.5 \mathrm{C})(\mathrm{b}+5 \mathrm{C})
$$

The integral of equation (3) is complex:

$k \tau=(1 / a b) \ln \left[C_{i} / C\right]+[1.5 / a(5 a-1.5 b)] \ln \left[\left(a+1.5 C_{1 i}\right) /(a+1.5 C)\right]+[5 / b(1.5 b-5 a)] \ln \left[\left(b+5 C_{2 j}\right) /(b+5 C)\right]$

but it satisfactorily describes the experimental kinetics and can be used to estimate the time required to oxidize $\mathrm{Cr}$ (III) hydroxide to a given extent by persulfate under selected reagent concentrations. In using equation (4), one must recognize that the value of $\mathrm{k}$ can change depending on the $\mathrm{Cr}$ (III) hydroxide compound and the reaction temperature being used. This stipulation is confirmed by the data presented in Table 5.4, which show the variation of $k$ observed at given temperatures found for the seven $\operatorname{Cr}$ (III) hydroxide compounds. The $\mathrm{k}$ values do not vary regularly as a function of precipitate aging conditions. The lack of correlation may reflect the poor reproducibility of the initial $\mathrm{Cr}$ (III) hydroxide precipitation conditions.

Table 5.4. Effect of $0.03 \mathrm{M} \mathrm{Cr}$ (III) Hydroxide Compound on the Rate Constant $\mathrm{k}$ in $0.2 \mathrm{M}$ Persulfate

\begin{tabular}{|c|c|c|c|c|c|}
\hline \multirow{2}{*}{$\begin{array}{c}\text { Compound } \\
\text { Number }\end{array}$} & \multirow{2}{*}{$\begin{array}{c}\text { Aging } \\
\text { Temperature, }\end{array}{ }^{\circ} \mathrm{C}}$, & \multicolumn{4}{|c|}{$\mathrm{k}$, liter $^{2} / \mathrm{moles}^{2}$-minute } \\
\cline { 3 - 6 } & and Time, days & \multicolumn{2}{|c|}{$2 \mathrm{M} \mathrm{NaOH}$} & \multicolumn{2}{c|}{$0.5 \mathrm{M} \mathrm{NaOH}$} \\
\cline { 3 - 6 } & 20,1 & 0.25 & 0.068 & - & 0.041 \\
\hline I & $20, \mathrm{C}$ & $50^{\circ} \mathrm{C}$ & $70^{\circ} \mathrm{C}$ & $50^{\circ} \mathrm{C}$ \\
\hline II & 100,15 & 0.33 & 0.071 & 0.30 & 0.083 \\
\hline III & 100,20 & 0.34 & 0.10 & 0.27 & 0.080 \\
\hline IV & 100,20 & 0.19 & - & 0.19 & - \\
\hline V & 150,20 & 0.18 & 0.046 & 0.12 & 0.033 \\
\hline VI & 200,20 & 0.22 & 0.081 & 0.24 & 0.060 \\
\hline VIII & 250,20 & 0.39 & 0.11 & 0.30 & 0.11 \\
\hline
\end{tabular}

\subsection{Data on Persulfate Reactions with Other Cr(III) Compounds}

Preliminary data on the reaction of persulfate with other $\mathrm{Cr}$ (III) compounds in alkaline media are given in Table 5.5. The test results show that the oxidation of amorphous $\mathrm{NiCr}_{2} \mathrm{O}_{4} \cdot \mathrm{nH}_{2} \mathrm{O}$ and mixed $\mathrm{Fe}$ (III) and $\mathrm{Cr}$ (III) hydroxide compounds proceeds more rapidly than the oxidation of pure $\mathrm{Cr}$ (III) hydroxide under the same conditions. Even crystalline products obtained by $800^{\circ} \mathrm{C}$ calcination of $\mathrm{Cr}$ (III) hydroxide (compound $\mathrm{II}$ ) and $\mathrm{NiCr}_{2} \mathrm{O}_{4} \cdot 5 \mathrm{H}_{2} \mathrm{O}$ (compound $\mathrm{X}$ ) are oxidatively dissolved by persulfate in alkaline media. These respective calcined solids were found by x-ray diffractometry to be $\alpha-\mathrm{Cr}_{2} \mathrm{O}_{3}$ (Figure 5.6) and a mixture of $\alpha-\mathrm{Cr}_{2} \mathrm{O}_{3}$ and a spinel-type $\mathrm{Ni}$ (II) chromite, $\mathrm{NiCr}_{2} \mathrm{O}_{4}$ (Figure 5.7). More detailed study of these reactions, such as determining the effect of alkali concentration on the reactions' rates and stoichiometries, is required. 
Table 5.5. Oxidation of Different Cr(III) Compounds by $0.2 \mathrm{M}$ Persulfate in $2 \mathrm{M} \mathrm{NaOH}$

\begin{tabular}{|c|c|c|c|c|c|c|}
\hline $\begin{array}{l}\text { Compound } \\
\text { Number }\end{array}$ & $\begin{array}{l}\text { Compound } \\
\text { Composition }\end{array}$ & $\begin{array}{c}\text { Aging or } \\
\text { Calcination } \\
\text { Temperature, }{ }^{\circ} \mathrm{C}\end{array}$ & $\frac{[\mathrm{Cr}(\mathrm{III})]_{0},}{\mathrm{M}}$ & $\begin{array}{c}\text { Dissolution } \\
\text { Temperature, } \\
{ }^{\circ} \mathrm{C}\end{array}$ & $\begin{array}{c}\mathrm{V}_{\mathrm{o}} \\
\text { moles/liter- } \\
\text { minute }\end{array}$ & $\begin{array}{l}\text { Reaction } \\
\text { Time, } \\
\text { minutes }\end{array}$ \\
\hline \multirow[t]{2}{*}{$\mathrm{X}$} & \multirow[t]{2}{*}{$\mathrm{NiCr}_{2} \mathrm{O}_{4} \cdot 5 \mathrm{H}_{2} \mathrm{O}$} & \multirow[t]{2}{*}{100} & 0.038 & 50.0 & $-8 \times 10^{-3}$ & 10 \\
\hline & & & 0.027 & 39.5 & $2.4 \times 10^{-3}$ & 25 \\
\hline \multirow[t]{2}{*}{$\overline{X I}$} & \multirow[t]{2}{*}{$\mathrm{NiCr}_{2} \mathrm{O}_{4} \cdot 4 \mathrm{H}_{2} \mathrm{O}$} & \multirow[t]{2}{*}{200} & 0.028 & 39.5 & $-7 \times 10^{-3}$ & 8 \\
\hline & & & 0.018 & 50.0 & $>10 \times 10^{-3}$ & $<5$ \\
\hline- & $\mathrm{NiCr}_{2} \mathrm{O}_{4}$ & 800 & 0.015 & 50.0 & $0.5 \times 10^{-3}$ & 80 \\
\hline- & $\alpha-\mathrm{Cr}_{2} \mathrm{O}_{3}$ & 800 & 0.036 & 70.0 & $2.7 \times 10^{-3}$ & 50 \\
\hline \multirow[t]{2}{*}{$\overline{X I I}$} & \multirow[t]{2}{*}{$\mathrm{FeCr}_{2} \mathrm{O}_{4.5} \cdot 3 \mathrm{H}_{2} \mathrm{O}^{(\mathrm{a})}$} & \multirow[t]{2}{*}{100} & 0.023 & 39.5 & $1.6 \times 10^{-3}$ & 90 \\
\hline & & & 0.017 & 50 & $2.5 \times 10^{-3}$ & 40 \\
\hline \multirow[t]{2}{*}{ XIII } & \multirow[t]{2}{*}{$\mathrm{FeCr}_{2} \mathrm{O}_{4.5} \cdot 3 \mathrm{H}_{2} \mathrm{O}$} & \multirow[t]{2}{*}{200} & 0.030 & 39.5 & $2.5 \times 10^{-3}$ & 60 \\
\hline & & & 0.024 & 50 & $4.9 \times 10^{-3}$ & 30 \\
\hline
\end{tabular}
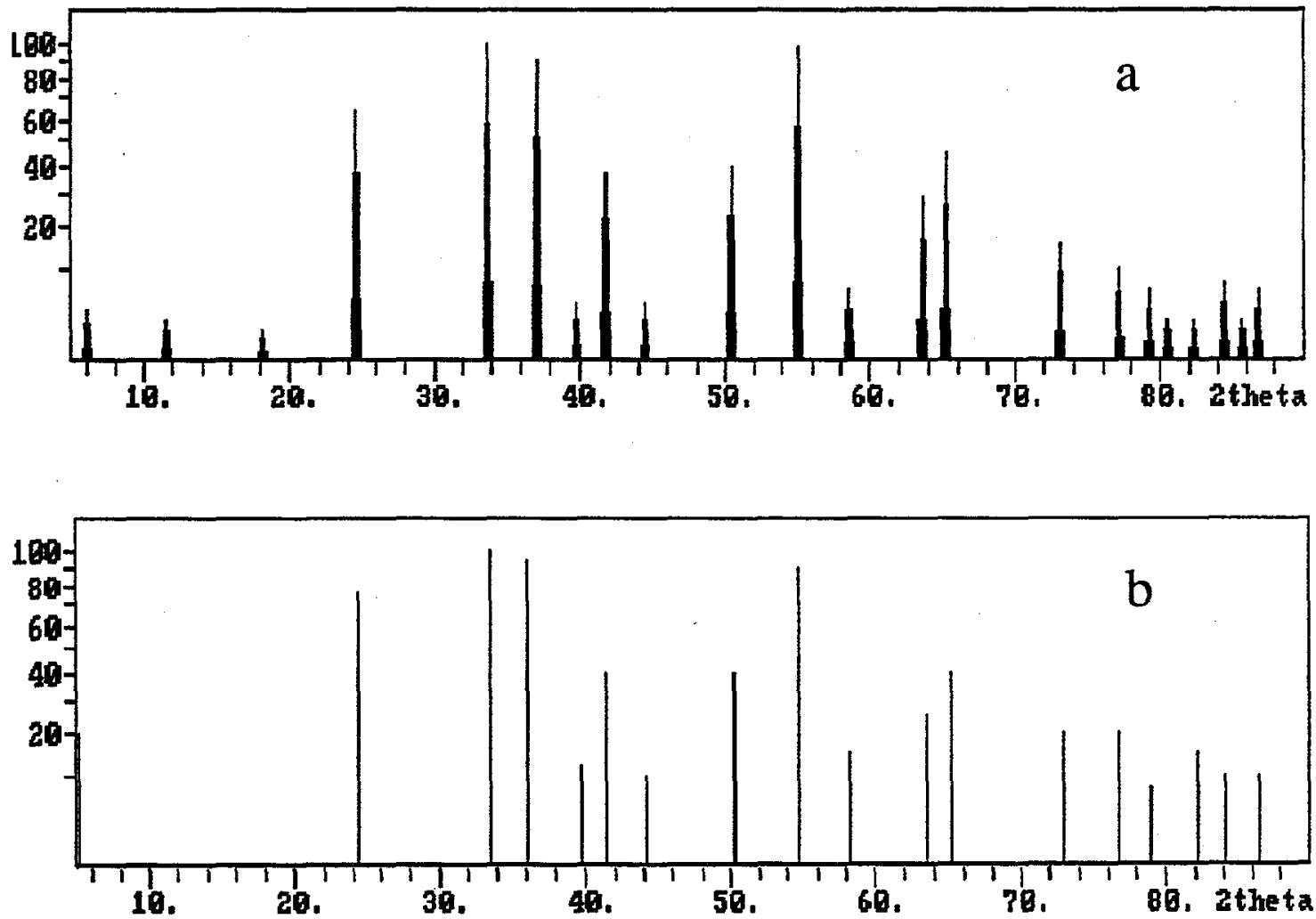

Figure 5.6. Diffractogram of $\mathrm{Cr}$ (III) Oxides a - $\mathrm{Cr}_{2} \mathrm{O}_{3} \cdot 3.8 \mathrm{H}_{2} \mathrm{O}$ (compound III) Calcined at $800^{\circ} \mathrm{C}$

b - Literature Data for $\alpha-\mathrm{Cr}_{2} \mathrm{O}_{3}$ [Newnhem and de Haan 1962] 

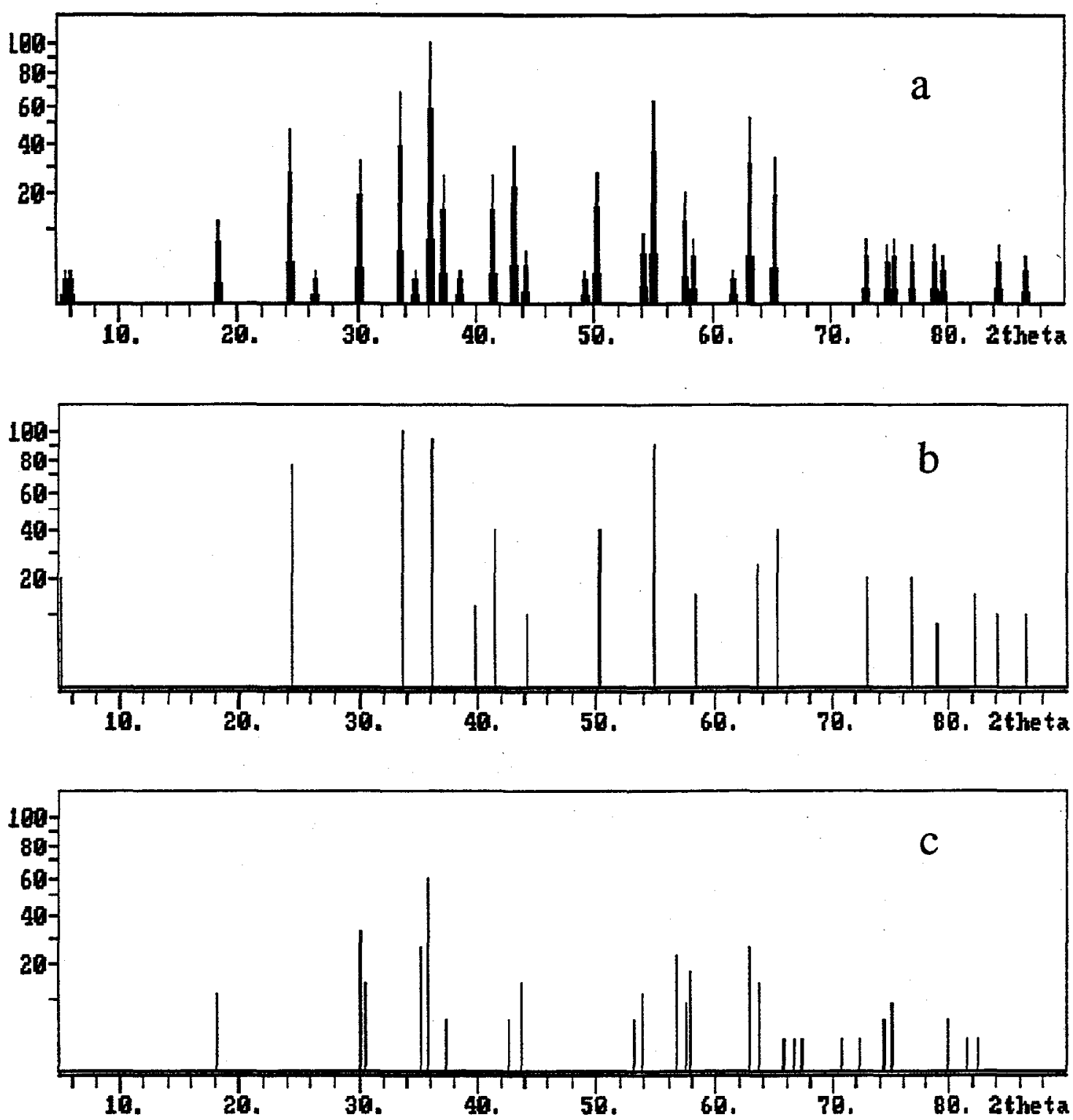

Figure 5.7. Diffractogram of $\mathrm{NiCr}_{2} \mathrm{O}_{4} \cdot$ Materials a - $\mathrm{NiCr}_{2} \mathrm{O}_{4} \cdot 5 \mathrm{H}_{2} \mathrm{O}$ (compound $\mathrm{X}$ ) calcined at $800^{\circ} \mathrm{C}$

b - $\alpha-\mathrm{Cr}_{2} \mathrm{O}_{3}$ [Newnhem and de Haan 1962]

c - $\mathrm{NiCr}_{2} \mathrm{O}_{4}$ spinel [JCPDS file 23-1272]

The high reactivity of mixed $\mathrm{Cr}$ (III) compounds toward persulfate can be explained by the catalytic effect of the associated $\mathrm{Ni}$ (II) or $\mathrm{Fe}$ (III). This hypothesis was confirmed by a number of additional tests. As seen in Table 5.6, the initial rate of $\mathrm{Cr}$ (III) hydroxide oxidation by persulfate in the presence of $\mathrm{Fe}(\mathrm{III}), \mathrm{Ni}$ (II), $\mathrm{Co}$ (II), and $\mathrm{Cu}$ (II) is significantly higher than that observed without the added d-elements under otherwise comparable alkaline conditions. Co(II) showed especially high catalytic activity. The catalysis likely is caused by the formation of intermediate reaction products of d-elements with persulfate in $\mathrm{NaOH}$ solution. 
Table 5.6. Initial Oxidation Rate of $0.03 \mathrm{M} \mathrm{Cr}$ (III) Hydroxide by $0.2 \mathrm{M}$ Persulfate in $50^{\circ} \mathrm{C} 2 \mathrm{M} \mathrm{NaOH}$ in the Presence of Some Catalysts

\begin{tabular}{|c|c|c|c|}
\hline \multirow{2}{*}{ Catalyst } & \multirow{2}{*}{ [Catalyst], M } & \multicolumn{2}{|c|}{$\begin{array}{c}\mathrm{V}_{\mathrm{o}} \text {, moles/liter-minute, for } \\
\text { compound number }\end{array}$} \\
\cline { 3 - 4 } & 0 & $\mathrm{II}$ & $\mathrm{VI}$ \\
\hline None & 0 & $1.3 \times 10^{-3}$ & $1.1 \times 10^{-3}$ \\
\hline \multirow{2}{*}{$\mathrm{Fe}(\mathrm{III})$} & $3 \times 10^{-4}$ & $1.3 \times 10^{-3}$ & $2.8 \times 10^{-3}$ \\
\cline { 2 - 4 } & $1 \times 10^{-2}$ & $1.5 \times 10^{-3}$ & $3.2 \times 10^{-3}$ \\
\hline \multirow{2}{*}{$\mathrm{Co}(\mathrm{I})$} & $3 \times 10^{-4}$ & $3.2 \times 10^{-3}$ & $\sim 6 \times 10^{-3}$ \\
\cline { 2 - 4 } & $1 \times 10^{-2}$ & $4.5 \times 10^{-3}$ & $11 \times 10^{-3}$ \\
\hline \multirow{2}{*}{$\mathrm{Ni}(\mathrm{II})$} & $3 \times 10^{-4}$ & $2.2 \times 10^{-3}$ & $3.8 \times 10^{-3}$ \\
\cline { 2 - 4 } & $1 \times 10^{-2}$ & $4.5 \times 10^{-3}$ & $5.2 \times 10^{-3}$ \\
\hline \multirow{2}{*}{$\mathrm{Cu}(\mathrm{II})$} & $3 \times 10^{-4}$ & $2.3 \times 10^{-3}$ & $3.1 \times 10^{-3}$ \\
\cline { 2 - 4 } & $1 \times 10^{-2}$ & $2.0 \times 10^{-3}$ & $3.4 \times 10^{-3}$ \\
\hline
\end{tabular}

The test data show persulfate to be a very effective reagent for the oxidative dissolution of $\mathrm{Cr}$ (III) solid phases in alkaline solution. Successful application of this oxidant to dissolution of $\mathrm{Cr}$ (III) from Hanford tank waste sludges of different origin and composition is expected because $\mathrm{S}_{2} \mathrm{O}_{8}{ }^{2-}$ reacts even with well-crystallized and stable $\mathrm{Cr}(\mathrm{III})$ compounds. The presence of iron and other d-elements in some sludges likely promotes $\mathrm{Cr}(\mathrm{III})$ oxidative dissolution through catalytic pathways. However, suppositions on the role of catalysis should be verified as part of a greater parametric study of persulfate interaction with different $\mathrm{Cr}(\mathrm{III})$ compounds and subsequent confirmatory tests with genuine Hanford tank waste sludges. 


\subsection{Summary and Conclusions}

Results obtained in the course of this investigation led to the following key conclusions concerning the oxidative dissolution of $\mathrm{Cr}$ (III) solid phases under alkaline conditions by oxygen gas, hydrogen peroxide, and persulfate. Studies were most extensive for $\mathrm{Cr}$ (III) hydroxide phases because they seem to be the most likely form of $\mathrm{Cr}(\mathrm{III})$ in Hanford tank sludge, especially after caustic treatment.

\section{Oxygen}

The rates of $\mathrm{O}_{2}$ reaction with aged amorphous $\mathrm{Cr}$ (III) hydroxides, as well as with other $\mathrm{Cr}$ (III) solid phase compounds, depend very strongly on $\mathrm{NaOH}$ concentration and, to a lesser extent, on temperature. Increase of either $\mathrm{NaOH}$ concentration or temperature significantly accelerates oxidative dissolution by oxygen to form soluble $\mathrm{Cr}(\mathrm{VI})$. Therefore, the choice of optimum reaction conditions also should account for the associated economic and technical reasons in addition to the impact of the reaction products and conditions on subsequent processing of the alkaline Cr(VI) leachates.

The oxidation of $\mathrm{Cr}(\mathrm{III})$ solid phases in alkaline solution by oxygen first requires dissolution of $\mathrm{O}_{2}$ gas into the solution phase. The concentration of dissolved oxygen and, in turn, the rates of oxidation were found to be proportional to the $\mathrm{O}_{2}$ partial pressure in the gas. As a result, using air instead of pure oxygen for oxidative leaching of chromium from the tank sludge decreases the rate of $\mathrm{Cr}$ (VI) formation four- to five-fold under otherwise similar conditions. Practical technical difficulties in attaining effective oxygen saturation of great volumes of alkaline sludge suspensions may be anticipated.

All experiments described in this report were performed using pure $\mathrm{Cr}$ (III) compounds. However, genuine tank sludges are complex and have variable composition with many elements. Genuine sludges, therefore, may catalyze the reaction of $\mathrm{Cr}$ (III) with oxygen. The catalytic action of $\mathrm{Ni}$ (II) on $\mathrm{Cr}$ (III) hydroxide oxidation by $\mathrm{O}_{2}$ was detected in this investigation. It is reasonable to suppose that oxidative chromium leaching from genuine tank sludges will proceed in some cases with higher rates than those found for the present tests with model sludge compounds.

Oxidative leaching of chromium from the Hanford tank sludge by oxygen has some advantages. One advantage concerns the expected behavior of plutonium, likely present as $\mathrm{Pu}(\mathrm{IV})$ hydrous oxide or sorbed as a Pu(IV) species on sludge solids in tank waste. Plutonium(IV) hydrous oxide has been shown not to react with oxygen and chromate in alkaline media [Shilov et al. 1996a]. Thus, it is reasonable to expect that $\mathrm{Cr}$ (VI) leachates, obtained by oxidation of $\mathrm{Cr}(\mathrm{III})$ solid compounds with oxygen, will not have enhanced plutonium concentrations, and thus facilitate their further processing.

\section{Hydrogen Peroxide}

Oxidative leaching of chromium(III)-bearing compounds by hydrogen peroxide was not always successful; it was particularly ineffective in the presence of greater than $0.5 \mathrm{~g} \mathrm{Fe}$ (III)/liter and other catalysts for $\mathrm{H}_{2} \mathrm{O}_{2}$ decomposition. Hydrogen peroxide can oxidize and dissolve $\mathrm{Cr}$ (III) hydroxides that have not undergone prolonged aging at high temperatures. Such hydroxides may be formed by the metathesis of $\mathrm{Cr}$ (III)-bearing compounds (e.g. phosphates, silicates, mixed hydroxides with aluminum) in the course of alkaline leaching of Hanford tank sludge to dissolve aluminum- and phosphate-rich phases. Therefore, leaching using hydrogen peroxide should be tested on residues remaining after water and caustic washing of actual tank sludges. 
Optimum oxidative leaching of $\mathrm{Cr}(\mathrm{III})$ solid compounds from tank sludge by $\mathrm{H}_{2} \mathrm{O}_{2}$ is attained at low excess $\mathrm{NaOH}(0.02-0.1 \mathrm{M})$ and at temperatures higher than $80^{\circ} \mathrm{C}$. In determining the amount of excess $\mathrm{NaOH}$, it is necessary to account for the stoichiometric requirement of 1.5 moles of $\mathrm{OH}^{-}$per mole of $\mathrm{Cr}$ (III) in the reaction with $\mathrm{H}_{2} \mathrm{O}_{2}$. The $\mathrm{H}_{2} \mathrm{O}_{2}$ should be added slowly (over a period of one to two hours) in the form of a diluted (1-2 M) solution with intense stirring of the alkaline sludge suspension. By employing such conditions, the catalytic decomposition of the oxidant may be decreased. The $\mathrm{H}_{2} \mathrm{O}_{2}$ concentration has a greater influence on the $\mathrm{H}_{2} \mathrm{O}_{2}$ self-decomposition rate than on the $\mathrm{Cr}$ (III) oxidation rate. Therefore, maintenance of low $\mathrm{H}_{2} \mathrm{O}_{2}$ concentrations decreases the parasitic loss of $\mathrm{H}_{2} \mathrm{O}_{2}$ to selfdecomposition.

Treatment of Hanford tank sludge by oxidative dissolution of $\mathrm{Cr}$ (III) compounds in alkaline $\mathrm{H}_{2} \mathrm{O}_{2}$ may only be attractive with freshly formed $\mathrm{Cr}$ (III) hydroxides and not with aged $\mathrm{Cr}$ (III) solids or solids with significant concentrations of $\mathrm{H}_{2} \mathrm{O}_{2}$ decomposition catalysts. However, oxidation by $\mathrm{H}_{2} \mathrm{O}_{2}$ has a number of obvious advantages. First, it proceeds at low $\mathrm{NaOH}$ concentrations and leaves no residues in the waste. This allows the final leachates to have simpler compositions more amenable to subsequent processing. In addition, $\mathrm{Pu}(\mathrm{IV})$ is not oxidized or complexed by dilute $\mathrm{H}_{2} \mathrm{O}_{2}$ at low $\mathrm{NaOH}$ concentrations [Shilov et al. 1996b]. Therefore, $\mathrm{H}_{2} \mathrm{O}_{2}$ will not increase plutonium concentrations in the product leachates.

\section{Persulfate}

Oxidative dissolution of $\mathrm{Cr}$ (III) solid phases from Hanford tank sludge by persulfate is expected to be very effective and not strongly dependent on the sludge composition, provided that the $\mathrm{Cr}$ (III) is present at the solid surface and not entrapped in an otherwise low-solubility phase [e.g., $\mathrm{Cr}$ (III) substituted in $\mathrm{Al}_{2} \mathrm{O}_{3}$ ]. This expectation is based on observation of the rapid oxidation of $\mathrm{Cr}$ (III) from stable crystalline compounds, including $\alpha-\mathrm{Cr}_{2} \mathrm{O}_{3}$, by persulfate in alkaline solution.

The molar reaction stoichiometry of $\mathrm{Cr}$ (III) with $\mathrm{S}_{2} \mathrm{O}_{8}{ }^{2-}$ at temperatures lower than $70^{\circ} \mathrm{C}$ is $1: 1.5$ and is not complicated by thermal decomposition of the oxidant. The optimum process conditions require reaction at $-70^{\circ} \mathrm{C}$ in $0.3-0.5 \mathrm{M}$ excess $\mathrm{NaOH}$. Under these conditions, complete $\mathrm{Cr}$ (III) oxidation is achieved in 1-2 hours.

The reaction of $\mathrm{Cr}$ (III) with persulfate in alkaline media is significantly accelerated in the presence of $\mathrm{Co}$ (II), $\mathrm{Ni}$ (II), and other d-element ions. Because of this, as in the case of oxygen, oxidative leaching of chromium from the genuine tank sludge by persulfate may proceed more rapidly or under milder conditions than described in the previous paragraph in the absence of catalysts.

It must be noted that persulfate is a very strong oxidant in alkaline media and can oxidize $\mathrm{Pu}(\mathrm{IV})$ to higher, more soluble, oxidation states [Shilov et al. 1996a]. Extensive plutonium dissolution therefore is expected in oxidative leaching of $\mathrm{Cr}(\mathrm{III})$ compounds from tank sludge by persulfate. Fortunately, a simple method exists to decrease the plutonium concentration in the leachate produced by the persulfate treatment. This method, heating the leachate to $80-90^{\circ} \mathrm{C}$ to decompose excess persulfate and then adding small amounts of $\mathrm{H}_{2} \mathrm{O}_{2}$ to reduce plutonium to $\mathrm{Pu}$ (IV) [Shilov et al. 1996b], is easily performed and should remove most plutonium from solution. without causing unwanted reduction of $\mathrm{Cr}(\mathrm{VI})$ to reprecipitate $\mathrm{Cr}(\mathrm{III})$ solid phases.

The test data show that persulfate is a promising reagent for oxidative leaching chromium from Hanford tank waste sludges. However, the reaction of $\mathrm{Cr}$ (III) compounds in various simulated and genuine sludges with persulfate in alkaline solution requires additional detailed parametric study. 


\subsection{References}

Berka A, J Vulterin, and J Zyka. 1961. Vybrané Oxydaene Redukenf Odmerné Metody. Praha (in Czech; available in English as Newer Redox Titrants, International Series of Monographs in Analytical Chemistry, V. 22, Pergamon Press, New York, p. 246).

Burwell RL, AB Littlewood, M Cardew, G Pass, and CTH Stoddart. 1960. "Reaction Between Hydrocarbons and Deuterium on Chromium Oxide Gel. I. General." J. Am. Chem. Soc. 82(24):62726280 .

Christensen AN. 1966. "The Crystal Structure of a New Polymorph of CrOOH." Inorg. Chem. 5(8):1452-1453.

Claydon MF, N Sheppard, BC Stace, and JA Upfield. 1975. "Alternative Explanation for the Anomalous Infrared Spectra of $\alpha$-Chromous Acid $\left(\mathrm{HCrO}_{2}\right)$ and $\alpha$-Chromous Acid-d $\left(\mathrm{DCrO}_{2}\right)$." J. Chem. Soc. Chem. Commun. (1):31-32.

Delegard CH, AM Stubbs, and SD Bolling. 1993. Laboratory Testing of Ozone Oxidation of Hanford Site Waste from Tank 241-SY-101. WHC-EP-0701, Westinghouse Hanford Company, Richland, Washington.

Delegard CH. 1995. Calcination/Dissolution Chemistry Development Fiscal Year 1995. WHC-EP0882, Westinghouse Hanford Company, Richland, Washington.

Farrow CJ and AR Burkin. 1975. "Alkali Pressure Leaching of Chromium(III) Oxide and of Chromite Mineral." Leaching and Reduction in Hydrometallurgy, AR Burkin, ed. Institute of Mining and Metallurgy, p. 20-27.

Felmy AR, D Rai, and RW Fulton. 1994. The Solubility of $\mathrm{Cr}(\mathrm{OH})_{3}(\mathrm{am})$ in Concentrated $\mathrm{NaOH}$ and $\mathrm{NaOH}-\mathrm{NaNO}_{3}$ Solutions. PNL-SA-24027, Pacific Northwest Laboratory, Richland, Washington.

Giacomelli CE, MJ Avena, OR Camara, and CP Pauli. 1995. "Some Physicochemical Properties of the Chromium(III) Hydrous Oxide - Aqueous Solution Interface." J. Colloid Interface Sci. 169(1):149-160.

Giovanoli R and W Stadelmann. 1973. "Über Kristallines Chrom(III) Hydroxid. II. Thermische Zersetzung" (Crystalline Chromium(III) Hydroxides. II. Thermal Decomposition). Thermochimica Acta 7(1):41-55 (in German).

Gmelin. 1962. Handbuch der Anorganischen Chemie. 8 Aufl., System-Numer 52, Chrom, Teil B, "Verbindungen" (Compounds) (in German).

Gmelin. 1963. Handbuch der Anorganischen Chemie. 8 Aufl., System-Numer 52, Chrom, Teil A, 676680 (in German).

Hund F. 1959. "Structur von $\gamma-\mathrm{CrOOH}$ ("Structure of $\gamma$-CrOOH"). Naturwissenschaften 4 (9):320-321 (in German).

Kittaka S, T Morooka, K Kitayama, and T Morimoto. 1985. "Thermal Decomposition of Chromium Oxide Hydroxide. I. Effect of Particle Size and Atmosphere." J. Solid State Chem. 58(2):187-193. 
Klissurski DG and VN Bluskov. 1983. "Effect of the Partial Pressures of Oxygen and Water Vapor on the Dispersity of $\alpha-\mathrm{Cr}_{2} \mathrm{O}_{3}$ Obtained by Thermal Decomposition of Hydrated Chromium(III) Oxide." Can. J. Chem. 61(3):457-460.

Kolthoff IM and IK Miller. 1951. "The Chemistry of Persulfate. I. The Kinetics and Mechanism of the Decomposition of the Persulfate Ion in Aqueous Medium." J. Am. Chem. Soc. 73(7):3055-3059.

Laubengayer AW and HW McCune. 1952. "New Crystalline Phases in the System Chromium(III) Oxide - Water." J. Am. Chem. Soc. 74(9):2362-2364.

Lumetta GJ, IE Burgeson, MJ Wagner, J Liu, and YL Chen. 1997. Washing and Caustic Leaching of Hanford Tank Sludge: Results of FY 1997 Studies. PNNL-11636, Pacific Northwest National Laboratory, Richland, Washington.

Markina EL and NW Freire. 1984. "Chemical Stability of Some Spinel Systems in Potassium Hydroxide Solutions." Izv. Vyssh. Uchebn. Zaved., Khim. Khim. Tekhnol. (Izvestiya Vysshykh Uchebnykh Zavedenii, Khimia i Khimicheskaya Tekhnologiya), 24(11):1278-1281 (in Russian; CA 102:33299g).

Mikhail RS and SA Selim. 1974. "Thermal Decomposition, Structural Changes, and Surface Properties of Chromium Oxide Gel." J. Appl. Chem. Biotechnol. 24(10):557-569.

Milligan WO. 1951. "Recent X-ray Diffraction Studies on the Hydrous Oxides and Hydroxides." $J$. Phys. \& Colloid Chem. 55(4):497-507.

Natarajan M and EA Secco. 1975. "Electrical Conductivity and Thermal Analysis Studies on Ferric Oxide and Chromic Oxide Gels." Phys. Status Solidi A, 30(2):K169-K172.

Newnhem RE and YM de Haan. 1962. "Refinement of the $\alpha \mathrm{Al}_{2} \mathrm{O}_{3}, \mathrm{Ti}_{2} \mathrm{O}_{3}, \mathrm{~V}_{2} \mathrm{O}_{3}$, and $\mathrm{Cr}_{2} \mathrm{O}_{3}$ Structures." Z. Krist. 117(2-3):235-237.

Plavnik GM. 1986. "Reconstruction of Particle Size Distributions and Anisotropy in Polydisperse Systems by the Small-Angle Scattering Method." Studia Biophysica 112(2-3):281-288.

Preudhomme J and P Tarte. 1971 . "Infrared Studies of Spinels. III. Normal II-III Spinels." Spectrochim. Acta, Part A 27(9):1817-1835.

Rapko BM, CH Delegard, and MJ Wagner. 1997. Oxidative Dissolution of Chromium from Hanford Tank Sludges under Alkaline Conditions. PNNL-11571, Pacific Northwest National Laboratory, Richland, Washington.

Rapko BM. 1998. Oxidative Alkaline Dissolution of Chromium from Hanford Tank Sludges: Results of FY 98 Studies. PNNL-11908, Pacific Northwest National Laboratory, Richland, Washington.

Ratnasamy P and AJ Leonard. 1972. "Structural Evolution of Chromia." J. Phys. Chem. 76(13):18381843.

Reznitskii LA, SE Filippova, and VK Portnoi. 1988. "Dehydration of Chromium(III) Hydroxide. The Crystallization Enthalpy of Amorphous Chromium Oxide and Its Solid Solutions in Ferric Oxide." Izv. Akad. Nauk SSSR Neorg. Mater. 24(9):1543-1546 (in Russian; available in English translation in the journal Inorganic Materials). 
Ryabin VA, MV Kireeva, NA Berg et al., eds. 1981. Neorganicheskie Soedineniya Khroma: Spravochnik (Inorganic Compounds of Chromium: Handbook, Khimia Publishing, Leningrad, USSR, in Russian).

Sass BM and D Rai. 1987. "Solubility of Amorphous Chromium(III)-Iron(III) Hydroxide Solid Solutions." Inorg. Chem. 26(14):2228-2232.

Shafer MW and R Roy. 1954. "Verbindungsbildung und Phasengleichgewichte in den Systemen $\mathrm{Cr}_{2} \mathrm{O}_{3}$ $\mathrm{H}_{2} \mathrm{O}, \mathrm{Sc}_{2} \mathrm{O}_{3}-\mathrm{H}_{2} \mathrm{O}$ und $\mathrm{Tl}_{2} \mathrm{O}_{3}-\mathrm{H}_{2} \mathrm{O}^{\prime \prime}$ ("Compound Formation and Phase Equilibrium in the Systems $\mathrm{Cr}_{2} \mathrm{O}_{3}-\mathrm{H}_{2} \mathrm{O}, \mathrm{Sc}_{2} \mathrm{O}_{3}-\mathrm{H}_{2} \mathrm{O}$, and $\mathrm{Tl}_{2} \mathrm{O}_{3}-\mathrm{H}_{2} \mathrm{O}^{\prime \prime}$ ). Z. anorg. u. allgem. Chem. 276(5-6):275-288 (in German).

Shilov VP, NN Krot, N Budantseva, A Yusov, A Garnov, V Perminov, and LN Astafurova. 1996a. Investigation of Some Redox Reactions of Neptunium, Plutonium, Americium, and Technetium in Alkaline Media. WHC-EP-0886, Westinghouse Hanford Company, Richland, Washington.

Shilov VP, LN Astafurova, AY Garnov, and NN Krot. 1996b. "Reaction of $\mathrm{H}_{2} \mathrm{O}_{2}$ with Suspensions of $\mathrm{Np}(\mathrm{OH})_{4}$ and $\mathrm{Pu}(\mathrm{OH})_{4}$ in Alkaline Media." Radiochemistry 38(3):217-219.

Simonova LA. 1973. Physico-Chemical Investigation of Chromium Hydroxide, Precipitated from Aqueous and Nonaqueous Solutions. Thesis, Kazan, USSR (in Russian).

Singh KK, PR Sarode, and P Ganguly. 1983. "Evolution of $\alpha$-Chromia from Hydrous Chromium Oxides: Magnetic Susceptibility and Extended x-ray Absorption Fine Structure Studies." J. Chem. Soc., Dalton Trans. (9):1895-1899.

Snyder RG and JA Ibers. 1962. "O-H-O and O-D-O Potential Energy Curves for Chromous Acid." $J$. Chem. Phys. 36(5):1356-1360.

Thamer BJ, RM Douglass, and E Staritzky. 1957. "Thermal Decomposition of Aqueous Chromic Acid and Some Properties of the Resulting Solid Phases." J. Am. Chem. Soc. 79(3):547-550.

Viktorov VV, AA Fotiev, and IV Evdokimov. 1994. "Effect of Preparation Conditions on Properties of Chromium Hydroxide and Products of Its Thermolysis." Izv. Akad. Nauk SSSR Neorg. Mater. 30(1):8790 (in Russian; available in English translation in the journal Inorganic Materials).

Voltz SE and SW Weller. 1954. "Decomposition of Aqueous Hydrogen Peroxide over Chromic Oxide Catalysts." J. Am. Chem. Soc. 76(6):1586-1587.

Whyatt GA, RJ Serne, SV Mattigod, Y Onishi, MR Powell, JH Westsik Jr, LM Liljegran, GR Golcar, KP Recknagle, PM Doctor, VG Zhirnov, and J Dixon. 1996. Potential for Criticality in Hanford Tanks Resulting from Retrieval of Tank Waste. PNNL-11304, Pacific Northwest National Laboratory, Richland, Washington.

Yur'eva TM, GK Boreskov, VI Zharkov, LG Karakchiev, VV Popovskii, and VA Chigrina. 1968. "Catalytic Properties of Chromites. I. Preparation of Copper, Nickel, Cobalt, Manganese, Zinc, Iron, and Magnesium Chromites." Kinet. Katal. (Kinetika i Kataliz), 9(6):1291-1295 (in Russian). 


\section{Distribution}

No. of

Copies

Offsite

2 DOE/Office of Scientific and Technical Information

T. E. Albert

American Russian Environmental

Services, Inc:

1059 Broadway, Suite G

Dunedin, FL 34698

2 Argonne National Laboratory

9700 South Cass Avenue

Argonne, IL 60439

ATTN: M. J. Steindler Technical Library

G. R. Choppin

Florida State University

Department of Chemistry, B164

Tallahassee, FL 32306-1096

$2 \quad$ Sue Clark

Washington State University

Pullman, WA 99164-4630

J. Covino

U.S. Defense Nuclear

Facilities Safety Board

625 Indiana Avenue NW, Suite 700

Washington, DC 20004

K. D. Gerdes

U.S. Department of Energy

EM-53 (Cloverleaf)

19901 Germantown Road

Germantown MD 20874

J. Harness

U.S. Department of Energy

Oak Ridge Operations Office

200 Administration Road

Oak Ridge TN 37830
No. of

Copies

Dennis J. Kelsh

Chemistry Department

Gonzaga University

502 E. Boone Ave.

Spokane, WA 99258

3 Lawrence Berkeley National Laboratory

One Cyclotron Road

Berkeley, California 94720

ATTN: Linfeng Rao (2)

MS 70A-1158

Technical Library

KNona Liddell

Washington State University

Pullman, WA 99164-2710

Los Alamos National Laboratory

P.O. Box 1663

Los Alamos, NM 87545

ATTN: Technical Library

$8 \quad$ Oak Ridge National Laboratory

P.O. Box 2008

Oak Ridge, TN 37831

ATTN: E. C. Beahm

J. T. Bell

W. D. Bond

E. Z. Egan

C. P. McGinnis

L. M. Toth

J. S. Watson

Technical Library

4 Savannah River Technical Center

P.O. Box 616

Aiken, SC 29808

ATTN: D. T. Hobbs

D. G. Karraker

M. C. Thompson

Technical Library 
No. of

Copies

W. W. Schulz

5314 Arbustos Court NE

Albuquerque, NM 87111

John Swanson

1318 Cottonwood Drive

Richland, WA 99352

Ian Tasker

Waste Policy Institute

555 Quince Orchard Road

Suite 600

Gaithersburg, MD 20878

R. G. Wymer

188-A Outer Drive

Oak Ridge, TN 37830

\section{Foreign}

23 Institute of Physical Chemistry

Russian Academy of Sciences

31 Leninsky Prospekt

Moscow

RUSSIA 117915

ATTN: L. N. Astafurova

N. A. Budantseva

I. A. Charushnikova

A. M. Fedoseev

A. Yu. Garnov

N. N. Krot (10)

T. S. Lapitskaya

V. I. Makarenkov

M. V. Nikonov

V. F. Peretrukhin

V. P. Perminov

A. K. Pikaev

V. P. Shilov

A. B. Yusov
No. of

Copies

Onsite

8 DOE Richland Operations Office

D. L. Biancosino

K8-50

D. A. Brown

$\mathrm{K} 8-50$

S. T. Burnum

A2-45

M. J. Glasper

K8-50

P. E. LaMont

A0-21

C. S. Louie

A0-21

B. A. Mauss

K8-50

C. R. Richins

K8-50

39 PHMC Team

W. C. Allan

R3-26

J. N. Appel

A3-03

G. S. Barney

T5-12

W. B. Barton

R2-11

D. B. Bechtold

T6-07

R. A. Bechtold

K7-22

M. A. Beck

T6-07

D. M. Bogen

$\mathrm{T} 2-12$

J. Bourges

$\mathrm{H} 0-34$

D. R. Bratzel

S7-73

K. G. Carothers

R2-11

S. A. Catlow

T6-50

A.-M. F. Choho

R3-73

T. D. Cooper

T5-12

R2-12

C. DeFigh-Price

T6-50

D. A. Dodd

T6-07

D. W. Edmonson

H0-34

T. A. Flament

R3-73

J. S. Garfield

H3-26

D. W. Hendrickson

T6-07

D. L. Herting

B. E. Hey

T6-07

J. O. Honeyman

R2-58

R. C. Hoyt

N1-20

J. R. Jewett

R3-73

R. A. Kirkbride

R3-73

M. J. Klem

R3-86

M. J. Kupfer 
No. of

Copies
S. L. Lambert
E. J. Lipke
G. T. MacLean
W. C. Miller
F. W. Moore
R. M. Orme
J. C. Person
D. A. Reynolds
J. P. Sloughter
D. J. Washenfelder
Central Files

$\underline{\text { SAIC }}$

D. J. Swanberg

H0-50

40

Pacific Northwest National Laboratory

S. Q. Bennett

K7-90

D. L. Blanchard

P7-25

W. F. Bonner (3)

N. G. Colton

K9-14

K2-12

R3-75

R1-49

B4-48

R3-11

H0-34

R3-73

T6-07

R2-11

HO-34

A3-03

A3-88
No. of

Copies

C. H. Delegard (10)

P7-25

A. R. Felmy K8-96

T. A. Fryberger K8-84

W. L. Kuhn

K7-15

D. E. Kurath

J. P. LaFemina

P7-28

P7-27

G. J. Lumetta

T. C. Maiti

S. V. Mattigod

G. K. Patello

D. Rai

B. M. Rapko

J. L. Ryan

A. J. Schmidt

R. J. Serne

D. M. Strachan

J. M. Tingey

D. W. Wester

G. A. Whyatt

K. D. Wiemers

Information Release (5)
P7-25

P7-07

K6-81

K6-24

P7-50

P7-25

P7-25

$\mathrm{K} 2-12$

K6-81

K6-24

P7-25

K7-74

K6-24

A0-21

K1-06 